\title{
Implications for the small mammal and earthworm communities in a degraded ecosystem
}

Jennifer Aaron Edalgo

West Virginia University

Follow this and additional works at: https://researchrepository.wvu.edu/etd

\section{Recommended Citation}

Edalgo, Jennifer Aaron, "Implications for the small mammal and earthworm communities in a degraded ecosystem" (2005). Graduate Theses, Dissertations, and Problem Reports. 2212.

https://researchrepository.wvu.edu/etd/2212

This Thesis is protected by copyright and/or related rights. It has been brought to you by the The Research Repository @ WVU with permission from the rights-holder(s). You are free to use this Thesis in any way that is permitted by the copyright and related rights legislation that applies to your use. For other uses you must obtain permission from the rights-holder(s) directly, unless additional rights are indicated by a Creative Commons license in the record and/ or on the work itself. This Thesis has been accepted for inclusion in WVU Graduate Theses, Dissertations, and Problem Reports collection by an authorized administrator of The Research Repository @ WVU. For more information, please contact researchrepository@mail.wvu.edu. 


\title{
Implications for the Small Mammal and Earthworm Communities in a Degraded Ecosystem
}

\author{
Jennifer Aaron Edalgo
}

Thesis submitted to the Davis College of Agriculture, Forestry, and Consumer Sciences at West Virginia University in partial fulfillment of the requirements for the degree of

Master of Science

in

Wildlife and Fisheries Management

James T. Anderson, Ph.D., Major Advisor

Constance A. Ranson, M.S., Committee Member

John W. Edwards, Ph.D., Committee Member

Division of Forestry

\author{
Morgantown, West Virginia \\ 2005
}

Keywords: earthworm, Morrow's honeysuckle, microhabitat selection, prebaiting, restoration, small mammal

Copyright 2005 Jennifer A. Edalgo 


\title{
Abstract \\ Implications for the Small Mammal and Earthworm Communities in a Degraded Ecosystem
}

\author{
Jennifer A. Edalgo
}

At Fort Necessity National Battlefield, Pennsylvania, we trapped small mammals in areas dominated by Morrow's honeysuckle, an invasive shrub, and we determined that prebaiting 1 and 2 days before the actual trapping period did not improve trapping success. We do not recommend using the added resources (i.e., time, money, personnel, and equipment) to incorporate prebaiting into trapping regimes because trapping success was not improved. We fluorescent powdertracked mice in old field and forested areas with Morrow's honeysuckle encroachment to determine the microhabitat they selected. Mice selected paths with high shrub and tree cover and low herbaceous cover. They selected native herbaceous vegetation and avoided exotic vegetation.

We determined shrubs (native and exotic) and soil characteristics that were associated with 4 earthworm species. Earthworm densities were largely dependent upon the shrub species and this will be useful for understanding the effects that worms may have on soil conditions and shrub species. 


\section{ACKNOWLEDGMENTS}

I thank the National Park Service and Fort Necessity National Battlefield (FONE) in Farmington, Pennsylvania for funding and resources. I thank my major advisor, committee member, and mentor, James T. Anderson for granting me the freedom to seize my education and learn as much as I desired, and for guidance throughout this research. I thank Connie Ranson, Natural Resource Specialist at FONE, for her consistent support in all of the projects, for securing a Student Conservation Association (SCA) crew to assist in field work, and for reviewing this manuscript. I thank my committee member John W. Edwards for reviewing this manuscript. I thank Jason P. Love, my fellow graduate student on this FONE project, for a great deal of field assistance, support, and determined teamwork in the field and the office. I thank Patrick Bohlen of the MacArthur Agroecology Research Center for identifying the earthworm specimens. Bill Grafton never tired at helping to identify many unknown plant species. Mark Hepner, Jason Alexander, Jennifer Love, Robbie Edalgo, LeAnne Bonner, Joe Osbourne, Lisa Tager, Ryan Ward, Ann Anderson, Ketan Tatu, Bridgett Crokus, and Kelly Perkins from West Virginia University (WVU) assisted with field work and I am grateful for their energy. I appreciate the help from George Seidel for statistical guidance and from Mike Henderson for GIS assistance. The WVU Animal Care and Use Committee (ACUC) approved our animal handling protocols (04-0104). 


\section{TABLE OF CONTENTS}

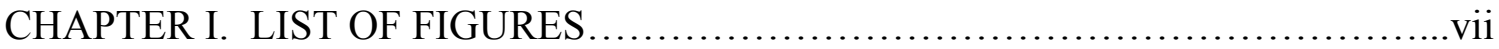

CHAPTER II. LIST OF TABLES ..................................................

CHAPTER II. LIST OF FIGURES...................................................

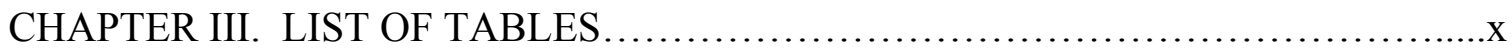

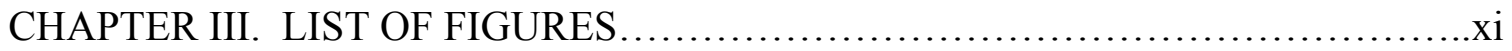

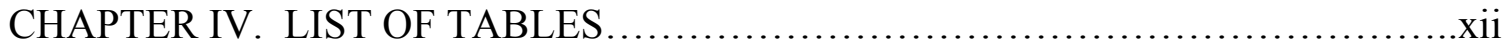

CHAPTER IV. LIST OF FIGURES...............................................

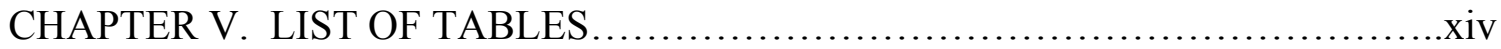

CHAPTER V. LIST OF FIGURES ...............................................

LIST OF APPENDICES.........................................................

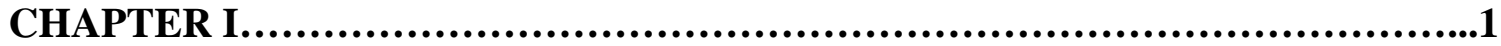

INTRODUCTION AND JUSTIFICATION FOR THE FORT NECESSITY

NATIONAL BATTLEFIELD RESTORATION PROJECT ..........................1

INTRODUCTION AND JUSTIFICATION ...............................

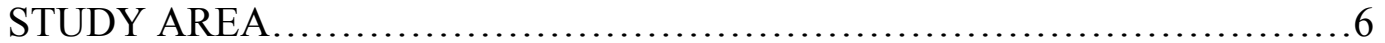

HYPOTHESES AND OBJECTIVES .......................................

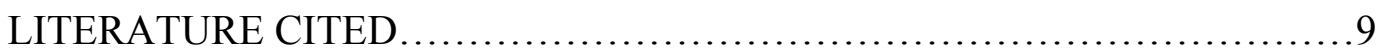

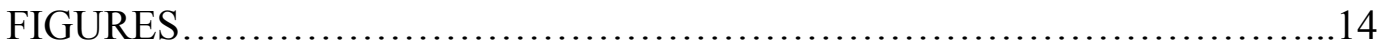

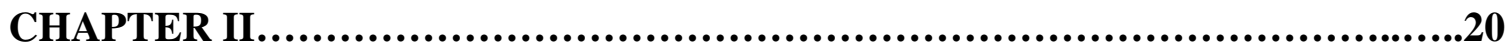

PREBAITING EFFECTS ON SMALL MAMMAL TRAPPING SUCCESS IN A MORROW'S HONEYSUCKLE DOMINATED AREA............................20

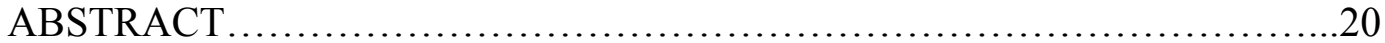

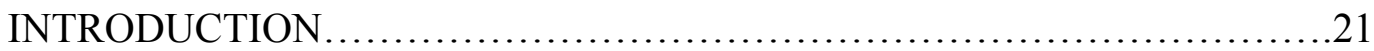

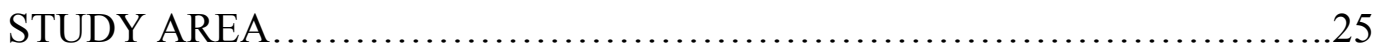

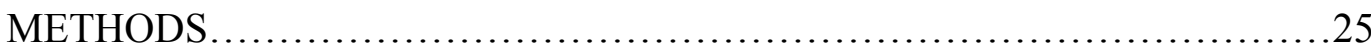

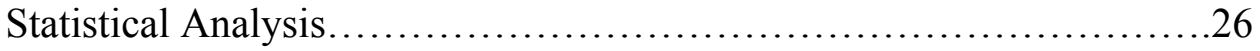

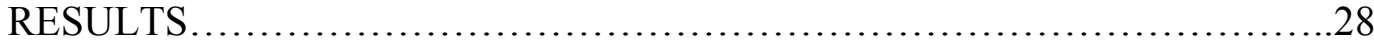

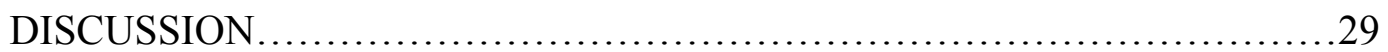

MANAGEMENT IMPLICATIONS............................................

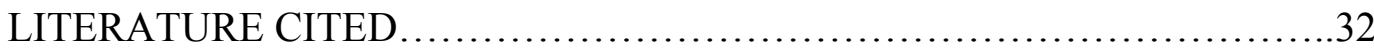

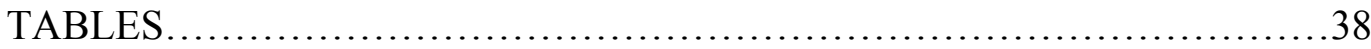

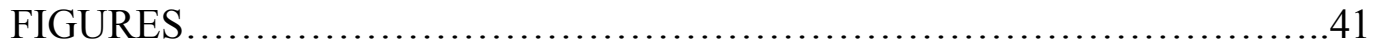

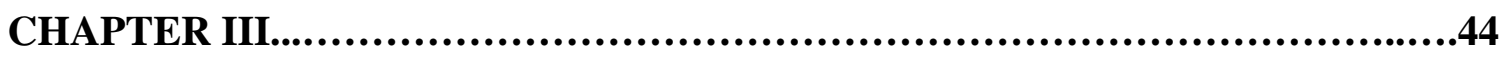

MICROHABITAT SELECTION OF PEROMYSCUS LEUCOPUS IN MORROW'S

HONEYSUCKLE INVADED SITES............................................44 


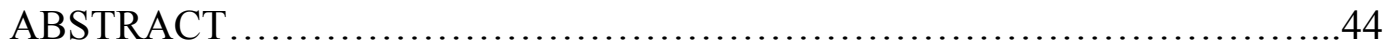

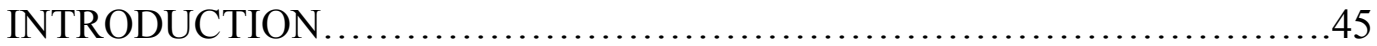

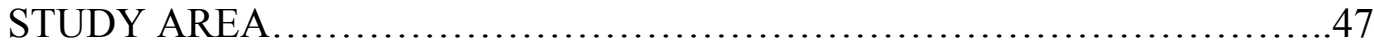

MATERIALS AND METHODS ......................................... 48

Statistical Analysis................................................... 50

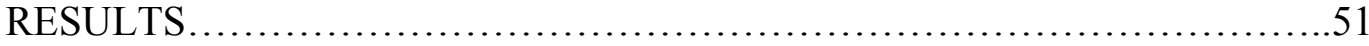

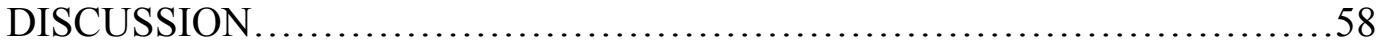

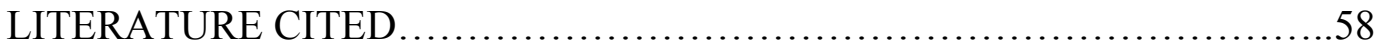

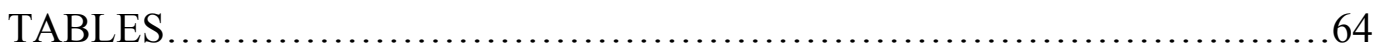

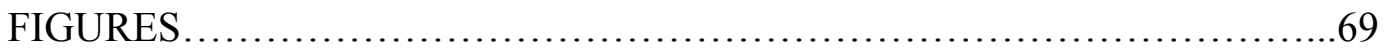

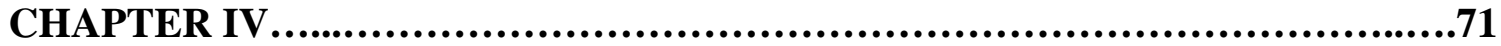

PREDICTING FACTORS THAT DRIVE EARTHWORM COMMUNITIES FOR

RESTORING A DEGRADED ECOSYSTEM.....................................71

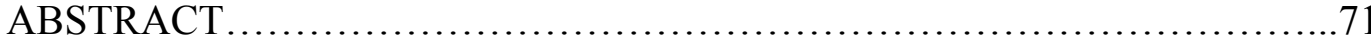

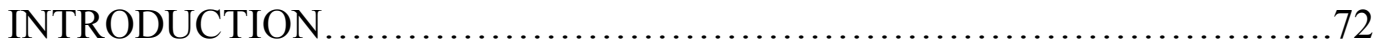

MATERIALS AND METHODS................................................ 74

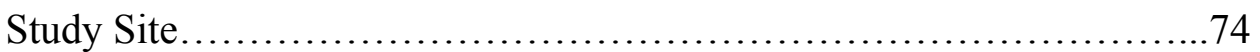

Earthworm Sampling............................................ 76

Additional Predictive Parameters......................................76

Statistical Analysis.................................................... 78

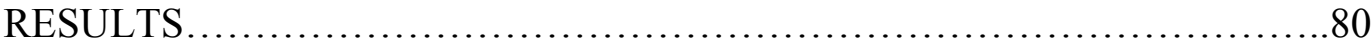

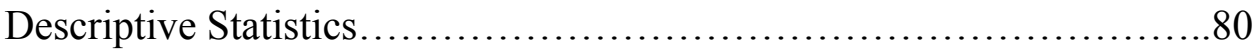

Model Selection................................................... 81

Eisenia rosea................................................. 81

Lumbricus rubellus............................................ 81

Lumbricus terrestris.............................................. 81

Octolasion tyrtaeum....................................... 82

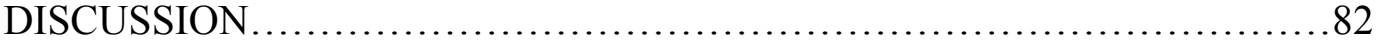

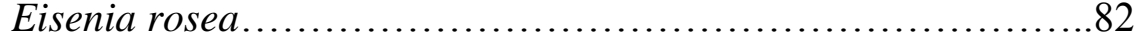

Lumbricus rubellus...............................................83

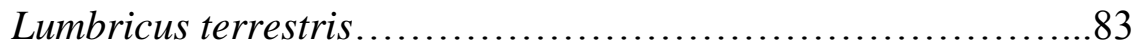

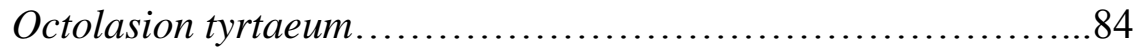

Restoration Implications ......................................... 86

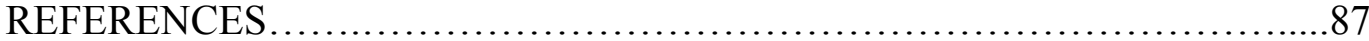

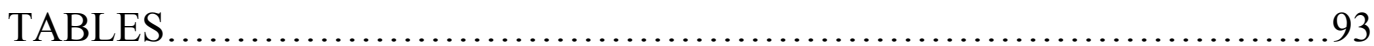

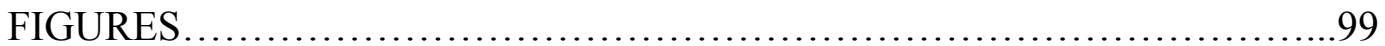




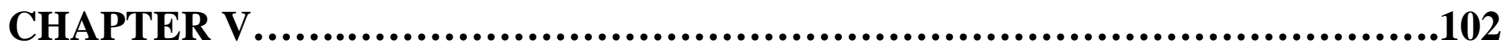

CONCLUSIONS AND MANAGEMENT IMPLICATIONS FOR SMALL MAMMALS AND THE EARTHWORM COMMUNITY IN A DEGRADED

ECOSYSTEM..................................................................102

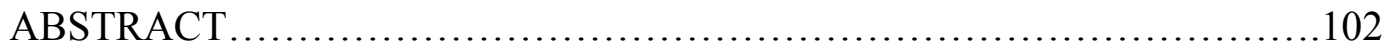

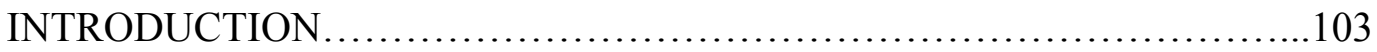

Restoration...................................................... 103

Small Mammals................................................104

Earthworms................................................... 105

STUDY AREA AND METHODS .......................................106

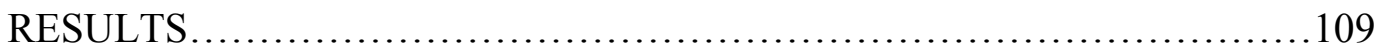

Small Mammals.................................................109

Earthworms......................................................111

CONCLUSIONS ........................................................ 112

Small Mammals..................................................112

Earthworms.........................................................

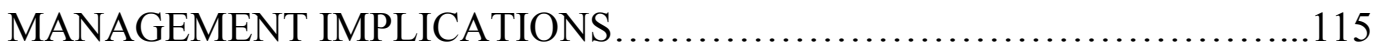

Small Mammals................................................115

Earthworms...................................................... 117

FUTURE RESEARCH............................................. 118

Small Mammals................................................. 118

Earthworms....................................................... 119

LITERATURE CITED .................................................. 120

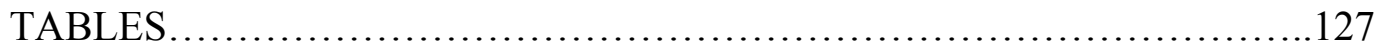

FIGURES ..................................................... 128

APPENDICES...............................................................129 


\section{CHAPTER I. LIST OF FIGURES}

Figure 1. Modified from Landers (1997). Restoration planning can be thought of as either top-down or bottom-up (Morrison 2002). The top-down approach to be used in this study aims to rehabilitate the site to a previous functional condition. This project has been focused on the top 2 portions of the triangle, setting up the restoration by understanding the biotic and abiotic conditions at the study site. The bottom area should be the focus of future research in restoring and replanting the area (Landers 1997)......14

Figure 2. The wooden fort constructed in the Great Meadows by George Washington (British) in 1754 has been replaced with a replica which stands today in the same location for visitors to see. The fort could hold approximately 50 men at the time of battle, and the rest of his troops filled the shallow trenches they had dug around the structure. The French and Native American force attacked George Washington's troops from the line of trees that bordered the meadow and served as shelter from the rain ...................15

Figure 3. Morrow's honeysuckle (Lonicera morrowii) is a bush honeysuckle with elliptic to oblong gray-green leaves that are pubescent beneath. The leaves are $3-6 \mathrm{~cm}$ long, with white flowers that fade to yellow. The flowers are pubescent, $1.5-2 \mathrm{~cm}$ long and are attached to densely hairy peduncles $5-15 \mathrm{~mm}$ long. The fruits are red and high in carbohydrates (Williams 1999). The shrub reaches a height of $2 \mathrm{~m}$ (Gleason and Cronquist 1991). Twigs of Morrow's honeysuckle are hairy and hollow (Petrides 1972)

Figure 4. The Fort Necessity National Battlefield in Fayette County, Pennsylvania, USA........................................................... 17

Figure 5. A topographic map of Fort Necessity National Battlefield in Fayette County,

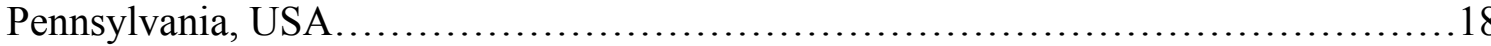

Figure 6. A map depicting the soils at Fort Necessity National Battlefield in Fayette County, Pennsylvania, USA. Soils include the following: Brinkerton and Armagh silt loams (BaB), Cavode silt loams (CaC2), Gilpin channery silt loams (GcC2), and Philo

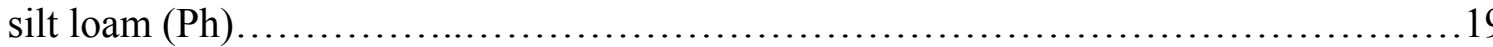




\section{CHAPTER II. LIST OF TABLES}

Table 1. Mammalian species captured (total number of captures and number of unique individuals) at Fort Necessity National Battlefield in Fayette County, Pennsylvania, USA

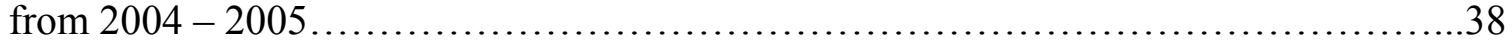

Table 2. Species richness, Simpson's index of diversity, and relative abundance (total individuals captured per 100 trap nights) for 3 prebaiting methods on 4 trapping grids dominated by Morrow's honeysuckle (Lonicera morrowii) at Fort Necessity National Battlefield in Fayette County, Pennsylvania, USA in 2004 and 2005.....................39

Table 3. Species richness, Simpson's Index of Diversity, and relative abundance (total individuals captured per 100 trap nights) for 4 months at Fort Necessity National Battlefield in Fayette County, Pennsylvania, USA in 2004 and 2005 ....................40 


\section{CHAPTER II. LIST OF FIGURES}

Figure 1. The Fort Necessity National Battlefield in Fayette County,

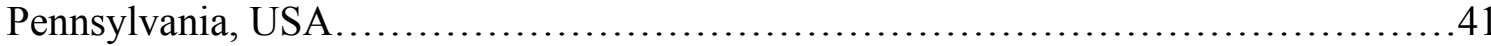

Figure 2. Estimate of $\%$ shrub and tree cover on each of the small mammal grids (Nursery, Fort, Upland, and Zoo) at Fort Necessity National Battlefield in Fayette County, Pennsylvania, USA in 2004 and 2005. Lonicera morrowii was the dominate

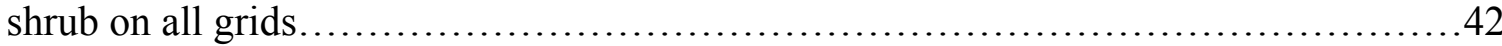

Figure 3. Locations of small mammal grids at Fort Necessity National Battlefield in Fayette County, Pennsylvania, USA during 2004 and 2005. The four grids, each $80 \mathrm{x}$ $120 \mathrm{~m}$, were located in the densest areas of the Morrow's honeysuckle (Lonicera morrowii) invasion. 


\section{CHAPTER III. LIST OF TABLES}

Table 1. Results from univariate ANOVAs and sample estimates of the treatment means and SE for each of the 4 habitat variables (\% cover) measured at Fort Necessity National Battlefield in Fayette County, Pennsylvania, USA in 2004 and 2005

Table 2. Dominant native and exotic herbaceous species at trap stations ( $n=128 ; 1,280.0$ $\mathrm{m}$ total distance) and along animal trails $(n=135 ; 1,224.15 \mathrm{~m}$ total distance) at Fort Necessity National Battlefield in Fayette County, Pennsylvania, USA in 2004 and 2005.

Table 3. Results from univariate ANOVAs on herbaceous indices (richness, diversity, and evenness) and sample estimates of the treatment means and SE for each of the 3 habitat variables (\% cover) measured at Fort Necessity National Battlefield in Fayette County, Pennsylvania, USA in 2004 and 2005

Table 4. Comparison of the number of trap nights and white-footed mice (Peromyscus leucopus) capture rates from this study at Fort Necessity National Battlefield in Fayette County, Pennsylvania, USA from 2004-2005 to other small mammal studies throughout

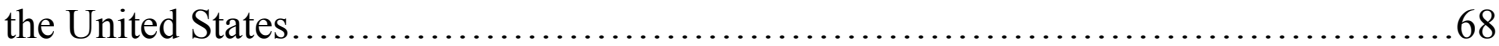




\section{CHAPTER III. LIST OF FIGURES}

Figure 1. The Fort Necessity National Battlefield in Fayette County,

Pennsylvania, USA.............................................................69

Figure 2. Locations of small mammal grids at Fort Necessity National Battlefield in Fayette County, Pennsylvania, USA during 2004 and 2005. The four grids were located outside the study area where separate studies took place; two of the grids (Sherwood and Rosewood) were located in the forest, while the remaining 2 grids (Heaven and Lovefield) were located in old fields. 


\section{CHAPTER IV. LIST OF TABLES}

Table 1. Mean earthworm densities (number of worms per square meter) and standard errors (SE) for each earthworm species captured underneath the various shrub/tree species at Fort Necessity National Battlefield in Fayette County, Pennsylvania, USA in August, and September of 2004 and in May, June, and August of 2005.................93

Table 2. Means and standard errors of soil variables associated with each shrub/tree species and in open spaces at Fort Necessity National Battlefield in Fayette County, Pennsylvania, USA from plots in August 2004 and May 2005

Table 3. Summary of a priori models to predict abundance of earthworms at Fort Necessity National Battlefield in Fayette County, Pennsylvania, USA from May 2004

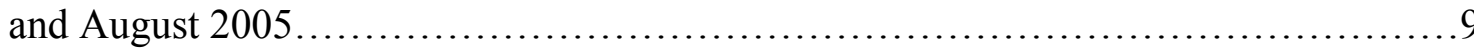




\section{CHAPTER IV. LIST OF FIGURES}

Figure 1. The Fort Necessity National Battlefield in Fayette County,

Pennsylvania, USA.........................................................99

Figure 2. Percentage of each earthworm species collected from all plots at Fort Necessity National Battlefield in Fayette County, Pennsylvania, USA from $2004-2005$. N = 290 plots Total worms $=1,459$ individuals .................................... 100

Figure 3. Mean density (earthworms per square meter) and standard error of each earthworm species pooled across all shrub/tree plots and open plots in all months at Fort Necessity National Battlefield in Fayette County, Pennsylvania,

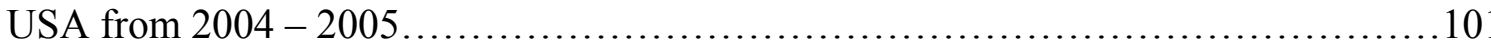




\section{CHAPTER V. LIST OF TABLES}

Table 1. We captured 11 species of small mammals at Fort Necessity National Battlefield in Fayette County, Pennsylvania, USA from 2004 - 2005 using Sherman live traps. The grids Nursery, Fort, Zoo, and Upland were trapped for Chapter 2 and were located in the densest Morrow's honeysuckle areas. The grids included in Forest and Field were trapped for Chapter 3 and included about 13\% Morrow's honeysuckle

invasion............................................................... 12 


\section{CHAPTER V. LIST OF FIGURES}

Figure 1. The Fort Necessity National Battlefield in Fayette County,

Pennsylvania, USA ..................................................... 128 


\section{LIST OF APPENDICES}

Appendix IIa. Species richness, Simpson's index of diversity, and relative abundance (total individuals captured per 100 trap nights) based on captures during 1 night of trapping for 3 prebaiting methods on 4 trapping grids dominated by Morrow's honeysuckle (Lonicera morrowii) at Fort Necessity National Battlefield in Fayette County, Pennsylvania, USA in 2004 and 2005

Appendix IIb. Average coverage (\%) of shrub species that occurred on the 4 small mammal grids used to test the effects of prebaiting at Fort Necessity National Battlefield in Fayette County, Pennsylvania, USA from 2004-2005 .............................131

Appendix III. Acronym, scientific name, and common name of herbs, shrubs, and trees that were measured at trap stations and along animal trails at Fort Necessity National Battlefield (FONE), Fayette County, Pennsylvania, USA in 2004 and 2005. Bold-faced type indicates exotic species.................................................... 132

Appendix IVa. Location of the earthworm plots at Fort Necessity National Battlefield (FONE) in Fayette County, Pennsylvania, USA during 2004 and 2005. Two hundred and ninety earthworm plots were dug within the area outlined by the yellow line....

Appendix IVb. Depiction of the soil types within the earthworm sampling boundary at Fort Necessity National Battlefield in Fayette County, Pennsylvania, USA during 2004 and 2005. The soils include Philo silt loams $(\mathrm{Ph})$ in the wetland area, Brinkerton and Armagh silt loams $(\mathrm{BaB})$ on $0-8 \%$ slopes, Cavode silt loams $(\mathrm{CaC} 2)$ with $8-15 \%$ slopes, Gilpin channery silt loam $(\mathrm{GcC} 2)$ with $12-20 \%$ slopes.....................138

Appendix IVc. Mean earthworm densities (number of worms per square meter) and standard errors (SE) for each earthworm species captured underneath the shrub/tree species in each month (May, Jun., Jul., Aug., Sept.) and year (2004, 2005) at Fort Necessity National Battlefield in Fayette County, Pennsylvania.... 


\section{CHAPTER I}

2 December 2005

James T. Anderson

West Virginia University

PO Box 6125

Morgantown, WV 26506-6125

304-293-2941x2445; FAX 304-293-2441; E-mail jander25@wvu.edu

RH: Introduction for the small mammal and earthworm community study $\bullet$ Edalgo and Anderson

INTRODUCTION AND JUSTIFICATION FOR THE FORT NECESSITY NATIONAL BATTLEFIELD RESTORATION PROJECT

JENNIFER A. EDALGO, West Virginia University, PO Box 6125, Morgantown, WV 26506-6125, USA

JAMES T. ANDERSON, West Virginia University, PO Box 6125, Morgantown, WV 26506-6125, USA

Ecological hope fuels habitat restoration. Hope lies in reaching or maintaining a natural condition for the plant and wildlife species in a given area. Today with practical knowledge and scientific insight, restorationists can rely on more than simply passions and hope in bringing a degraded ecosystem through recovery. Holistic restorationists look beyond the immediate goals and additionally consider the future for maintaining viable populations of target species (Morrison 2002).

Ecological restoration has been defined as the process of assisting the recovery and management of ecological integrity (Halle and Fattorini 2004). Ecological integrity includes a critical range of variability in biodiversity, ecological processes and structures, regional and historical context, and sustainable cultural practices (Halle and Fattorini 
2004). Habitat restoration involves our understanding of how ecological processes regulate population trends (Morrison 2002). Even more basic, we must identify the endemic biota so that we can work at understanding it (Mooney and Hobbs 2000, Aronson and Falk 2002). By knowing how the existing biota functions in the degraded habitat and then documenting its change as the habitat is restored, future restoration in similar habitats becomes more predictable and achievable.

In developing a restoration plan for the Fort Necessity National Battlefield (FONE) restoration site in Fayette County, Pennsylvania, USA, Morrison's (2002) topdown approach best allocates time and budgetary constraints (Figure 1). The top-down restoration plan identifies the desired vegetative community and the major alterations are prioritized for planting and maintenance. During the restoration, vegetation is the primary consideration and hence wildlife haphazardly occupies the site. A separate study concurrently under way is examining the best methods to be used in restoring the site to its natural vegetative state, as well as documenting the invertebrate community. Moreover, baseline data on a diversity of vegetation and wildlife species are being collected. This study will document the small mammal community's diversity and distribution as well as the earthworm community's richness and evenness before the degraded site is restored.

Before determining the desired vegetative community, or reference state, the site's history and current conditions must be understood (Halle and Fattorini 2004). Fort Necessity National Battlefield was established in 1931 and is located in Fayette County in southwestern Pennsylvania (National Park Service 1991). The site lies in the Laurel Highlands portion of the Allegheny Mountains (Yahner et al. 2004). The centerpiece of 
the park is the replica of Fort Necessity, a hastily built fort erected in the Great Meadows by George Washington and his troops during the French-Indian War (National Park Service 1991; Figure 2). Two hundred and fifty years have passed since the battle at Fort Necessity and many changes have occurred in the Great Meadows and adjacent woodland. Much of the woodland was cleared for pasture and used for cattle grazing in the $19^{\text {th }}$ and early $20^{\text {th }}$ centuries. Prior to the mid-1980s, the Great Meadows and part of the adjacent slopes were frequently mowed to maintain the early successional habitat, but in 1985 mowing ceased and much of the area was allowed to grow naturally. After mowing ceased, the exotic and invasive Morrow's honeysuckle (Lonicera morrowii) invaded the disturbed area (National Park Service 1991; Figure 3).

The National Park Service takes an aggressive stance on the invasion of exotic species in America's parklands. The General Management Plan for Fort Necessity states that the forest will be managed to prevent damage by exotic species and the Park will manage species to help maintain health and diversity within the ecosystem, to ensure the continuation of rare, threatened, or endangered species, and to work toward reestablishing the vegetative conditions that existed during the historical period whenever possible (National Park Service 1991). For that reason, Fort Necessity National Battlefield has designated the historical time period when George Washington erected the fort as the desired "natural" vegetative community (National Park Service 1991). Morrow’s honeysuckle has invaded and dominates upland sites, and given that Morrow's honeysuckle was not present in the 1700 s, removing this undesirable species will be the first major action toward reestablishing the historical vegetative condition (Western Pennsylvania Conservancy 2003). By considering the whole ecosystem in this 
restoration project, the living and non-living components that make up the site need to be understood prior to implementing the restorative action.

Small mammals can be an integral part of an ecosystem in dispersing seeds, ingesting invertebrates, creating holes and tunnels underground, and themselves being a source of food to species in all vertebrate classes (Mazzotti et al. 1981; Longland and Clements 1995; Pearson et al. 2001). The main mammalian interest in this study was to determine species abundance and composition. Therefore, two topics will be explored dealing with the population of small mammals living in Morrow's honeysuckle on Fort Necessity. The first question of study involves a method of trapping called "prebaiting." Small mammal population density is commonly measured by trapping with box traps (live-traps; Morrison 2002). To improve trapping results, some studies suggest prebaiting the traps (Moore 1936; Chitty and Kempson 1949; Andersen 1994; Flowerdew et al. 2004). Prebaiting allows the animals to freely take the bait in the trap. During the night, the trap is baited and locked in the "open" position (Chitty and Kempson 1949; MacCracken et al. 1985; Andersen 1994). The next night, the trap is unlocked and put back into use so that an animal entering the trap will be caught (Chitty and Kempson 1949; MacCracken et al. 1985; Andersen 1994). The idea behind prebaiting is that animals become more familiar with the new objects (box traps) in their environment, hence they will enter the traps more readily when the traps are set (Chitty and Kempson 1949; Howard 1959; Gurnell 1980). Bowman et al. (2001) expressed surprise at how rarely prebaiting was practiced in small mammal studies; 7 out of 127 studies indicated that traps were prebaited. Bowman et al. (2001) states that there is limited evidence that more animals can be captured during a given trapping period by prebaiting. Considering 
the amount of time, money, equipment, and technical assistance trapping takes and the fact that various studies continue to add prebaiting into their trapping regimes, there is surprisingly little literature confirming the assumption that prebaiting improves capture rates. Prebaiting small mammal traps has not been studied using the methods we describe below, but more importantly, prebaiting has not been quantitatively studied to determine its usefulness in trapping regimes.

The second topic of study will employ tracking and trapping to examine the microhabitat used by small mammals living among Morrow's honeysuckle. Microhabitat is defined as the physical and chemical variables in the environment that influence the time and energy used by an individual in its home range (Morris 1987). Using fluorescent pigments to track the movements of small mammals was first used by Lemen and Freeman (1985), but many studies have used this method (Mullican 1988; Longland and Clements 1995; McCay 2000; Menzel et al. 2000). Researchers like the powdertracking method because it is non-inhibiting to the animal's movements, fairly inexpensive (\$2.20/kg of powder pigment, Radiant Color, Richmond, California), able to track the animal up to $900 \mathrm{~m}$, low in toxicity, and the powder can mark the animal's vertical movement up trees and stems (Sheppe 1967; Lemen and Freeman 1985). The shortcomings to using the powdertracking method are that it can be time consuming and the powdered animals may produce poor trails in sparsely vegetated areas (Lemen and Freeman 1985).

Wildlife managers and policy makers need to understand key habitat requirements for generalist small mammal species that serve vital roles in the ecosystem (Bellows et al. 2001). Although studies are lacking that examine effects of exotic plants on small 
mammal communities (Pearson et al. 2001), a few studies suggest that exotic plant invasions, especially Lonicera spp., have a high potential to alter small mammal ecology (Witmer 1996; Williams 1999). As bush honeysuckles continue to spread through the eastern United States (Batcher and Stiles 2004), it is imperative that we examine the microhabitat characteristics that small mammals select.

The ecosystem function is considered in this project where the living and the nonliving components meet; earthworms existing in the soil may prefer to live underneath certain plants to others. Knowledge of the distribution and abundance of earthworms in areas with spreading exotic plant species is not well addressed. Previously farmed land with moderately drained soil, like FONE, was found to have an extremely high biomass of earthworms (Owen and Galbraith 1989). Knowledge of earthworm abundance and species composition under Morrow's honeysuckle versus under other native shrubs and trees on FONE will allow management decisions to be based on the best data for reintroducing and promoting native vegetation.

\section{STUDY AREA}

Fort Necessity National Battlefield in Fayette County, Pennsylvania, USA covers 390 ha in the main park with elevations ranging from 535 - 710 m (National Park Service 1991; Figures 4 and 5). The average annual temperature is $9^{\circ} \mathrm{C}$ and the average annual precipitation is $119 \mathrm{~cm}$ (National Park Service 1991). The soil at FONE is Philo silt loam, which perpetuates the deciduous woodlands in riparian areas, and grasses, herbs, and shrubs in the Great Meadows (Kopas 1973; National Park Service 1991; Figure 6). On the upland sites, soils include moderately deep, moderate to well drained, and 
medium-textured soils underlain by acidic shale and sandstone bedrock (National Park Service 1991).

According to The Western Pennsylvania Conservancy (2003), the current composition of vegetation in the meadow and more elevated areas has been extensively disturbed and invaded by non-native species and no current documents for plant communities in Pennsylvania address these conditions, therefore, no formal type can be assigned to this plant community. The upland areas are predominately herbaceous with highly dense to sparse patches of shrubs. Morrow's honeysuckle envelops the upland sites, but species that occur with less frequency in the area include: wrinkleleaf goldenrod (Solidago rugosa), Aster spp., flat-top goldenrod (Euthamia graminifolia), nightshade (Solanum canadense), milkweed (Asclepias sp.), common yarrow (Achillea millefolium), bristly dewberry (Rubus hispidus), purple crownvetch (Coronilla varia), wild basil (Clinopodium vulgare), lamp rush (Juncus effuses), Southern arrowwood (Viburnum dentatum), American hogpeanut (Amphicarpaea bracteata), hawthorne (Crataegus sp.), blackeyed Susan (Rudbeckia hirta), multiflora rose (Rosa multiflora), Queen Anne's lace (Daucus carota), purple milkwort (Polygala sanguinea), and New York ironweed (Vernonia noveboracensis) (Western Pennsylvania Conservancy 2003).

\section{HYPOTHESES AND OBJECTIVES}

We hypothesize that prebaiting will improve trapping success compared to traps that are not prebaited; additionally, traps that are prebaited for 2 nights will capture more small mammals than the traps that are prebaited for 1 night. Traps with evidence of being entered and bait being eaten in the prebaiting period, will be the traps that small 
mammals also enter during the trapping period. The objectives used to assess this hypothesis are to:

1) Determine the amount of use traps are getting during the prebaiting stage when the traps are secured in the "open" position;

2) Determine small mammal species richness, species diversity, and relative abundance within exotic Morrow's honeysuckle; and

3) Compare the richness, diversity, and relative abundance of small mammals caught among the prebaited traps and the non-prebaited traps, as well as by year and month, and to quantify the effectiveness of prebaiting.

We hypothesized that white-footed mice (Peromyscus leucopus) would select paths with low density of herbs, native vegetation, and a high protection from predators, but avoid exotic vegetation. We also hypothesized that white-footed mice would not use shrubs, or trees more than their availability. Our objectives were to:

4) Determine the paths taken by fluorescent powdertracked small mammals within woodland and old field areas with encroaching Morrow's honeysuckle and record the microhabitat characteristics along each powder trail and at random trap stations; and

5) Determine use and selection of microhabitat characteristics by fluorescent powder-marked white-footed mice.

We hypothesize that earthworm species density will be found in decreasing abundance under black locust (Robina pseudoacacia), northern arrowwood (Viburnum dentatum), tulip-poplar (Liriodendron tulipifera), Morrow's honeysuckle, and open spaces, with native plants having more earthworms per square meter underneath them. 
The primary goal of this study was to determine the relation of earthworm communities to edaphic and biotic characteristics. Specific objectives were to:

6) Determine and compare earthworm abundance found underneath native and exotic shrub/tree species and in open spaces;

7) Relate the soil microhabitat underneath the shrub/tree species and open spaces to the earthworm abundance under the same shrub/tree species; and

8) Determine the importance of each existing shrub/tree species, or lack of shrubs/trees (open spaces) for the continuation of a healthy earthworm population, and to provide management recommendations prior to implementing restorative action.

\section{LITERATURE CITED}

AnDERSEn, D. C. 1994. Demographics of small mammals using anthropogenic desert riparian habitat in Arizona. Journal of Wildlife Management 58:445-454.

Aronson, J. And D. A. FalK. 2002. Series Introduction. Pages xv-xviii in M. L. Morrison, editor. Wildlife restoration. Island Press, Washington, D.C.

BATCHER, M. S. AND StiLES, S. A. Element Stewardship Abstract for the Bush Honeysuckles, The Nature Conservancy. http://tncweeds.ucdavis.edu/esadocs/documnts/loni_sp.html. Accessed February $10,2004$.

Bellows, A. S., J. F. Pagels, And J. C. Mitchell. 2001. Macrohabitat and microhabitat affinities of small mammals in a fragmented landscape on the upper coastal plain of Virginia. The American Midland Naturalist 146:345-360.

Bowman, J., C. V. Corkum, AND G. J. Forbes. 2001. Spatial scales of trapping in small-mammal research. The Canadian Field-Naturalist 115:472-475. 
Chitty, D. And D. A. Kempson. 1949. Prebaiting small mammals and a new trap design of live trap. Ecology 30:536-542.

Flowerdew, J. R., R. F. Shore, S. M. C. Poulton, And T. H. Sparks. 2004. Live trapping to monitor small mammals in Britain. Mammal Review 34:31-50.

GleAson, H. A. AND A CRONQUist. 1991. Manual of vascular plants of northeastern United States and adjacent Canada. Second edition. The New York Botanical Garden, Bronx, NY.

GURNELL, J. 1980. The effects of prebaiting live traps on catching woodland rodents. Acta Theriologica 25:255-264.

Halle, S. AND M. FAtTORINI. 2004. Advances in restoration ecology: insights from Aquatic and terrestrial ecosystems. Pages 10-33 in V. M. Temperton, R. J. Hobbs, T. Nuttle, and S. Halle, editors. Assembly rules and restoration ecology. Island Press, Washington, D.C.

How ARD, W. E. 1959. How to overcome bait shyness in rodents. Pest Control 27:913.

KeInAth, D. A. AND G. D. HAYwARD. 2003. Red-backed vole (Clethrionomys gapperi) response to disturbance in subalpine forests: use of regenerating patches. Journal of Mammalogy 84:956-966.

KopAs, F. A. 1973. Soil survey of Fayette County, Pennsylvania. United States Department of Agriculture/Soil Conservation Service, Washington, D.C.

LANDERS, D. H. 1997. Riparian restoration: current status and the reach to the future. Restoration Ecology 5:113-121. 
LEMEN, C. A. AND P. W. FrEEMAN. 1985. Tracking mammals with fluorescent pigments: a new technique. Journal of Mammalogy 66:134-136.

LONGLAND, W. S. AND C. ClEMENTS. 1995. Use of fluorescent pigments in studies of seed caching by rodents. Journal of Mammalogy 76:1260-1266.

MacCracken, J. G., D. W. Uresk, And R. M. Hansen. 1985. Rodent-vegetation relationships in southeastern Montana. Northwest Science 59:272-278.

Mazzotti, F. J., W. Ostrenko, And A. T. Smith. 1981. Effects of the exotic plants Melaleuca quinquenervia and Casuarina equisetifolia on small mammal populations in the eastern Florida Everglades. Florida Scientist 44:65-71.

MCCAY, T. S. 2000. Use of woody debris by cotton mice (Peromyscus gossypinus) in a southeastern pine forest. Journal of Mammalogy 81:527-535.

Menzel, M. A., T. C. CARTER, L. R. JABlonowski, AND J. LAERM. 2000. The effect of time of release on microhabitat use by the white-footed mouse. Acta Theriologica 45:167-173.

Mooney, H. A. And R. J. HobBS. 2000. Introduction. Pages xiii-xv in Mooney, H. A. and R. J. Hobbs, editors. Invasive species in a changing world. Island Press. Washington, D.C..

Moore, A. W. 1936. Improvements in live trapping. Journal of Mammalogy 17:372374.

MORRIS, D. W. 1987. Ecological scale and habitat use. Ecology 68:362-369.

Morrison, M. L. 2002. Sampling methods: wildlife restoration. Island Press, Washington, D.C. 
MulliCAN, T. R. 1988. Radio telemetry and fluorescent pigments: a comparison of techniques. Journal of Wildlife Management 52:627-631.

NAtional PARK SERVICE. 1991. General Management Plan/Development Concept Plan/Interpretive Prospectus: Fort Necessity National Battlefield. U. S. Department of the Interior Prepared by the Denver Service Center, Denver, CO.

OWEn, JR., R. B. AND W. J. GALBRAITH. 1989. Earthworm biomass in relation to forest types, soil, and land use: implications for woodcock management. Wildlife Society Bulletin 17:130-136.

Pearson, D. E., Y. K. Ortega, K. S. McKelvey, And L. F. Ruggiero. 2001. Small mammal communities and habitat selection in northern Rocky Mountain bunchgrass: implications for exotic plant invasions. Northwest Science 75:107117.

Petrides, G. A. 1972. A field guide to trees and shrubs: Northeastern and Northcentral U.S. and Southeastern and South-central Canada. Houghton Mifflin Company, Boston, MA.

SHEPPE, W. 1967. The effects of livetrapping on the movements of Peromyscus. The American Midland Naturalist 78:471-480.

Western Pennsylvania Conservancy. 2003. Plant community mapping and surveys for species of special concern at Allegheny Portage Railroad National Historic Site, Johnstown Flood National Memorial, Fort Necessity National Battlefield, and Friendship Hill National Historic Site. 
WiLliams, C. E. 1999. Fruits of alien shrubs and deer mice: a test of the persistent fruit defense hypothesis. Journal of the Pennsylvania Academy of Science 73:33-37.

WiTMER, M. C. 1996. Consequences of an alien shrub on the plumage coloration and ecology of Cedar Waxwings. Auk 113:735-743.

YAHNER, R. H., B. D. Ross, AND J. E. KUBEL, TECHNICAL COORDINATORS. 2004. Comprehensive inventory of birds and mammals at Fort Necessity National Battlefield and Friendship Hill National Historic Site. National Park Service Technical Report NPS/NERCHAL/NRTR. 
Figure 1. Modified from Landers (1997). Restoration planning can be thought of as either top-down or bottom-up (Morrison 2002). The top-down approach to be used in this study aims to rehabilitate the site to a previous functional condition. This project has been focused on the top 2 portions of the triangle, setting up the restoration by understanding the biotic and abiotic conditions at the study site. The bottom area should be the focus of future research in restoring and replanting the area (Landers 1997).

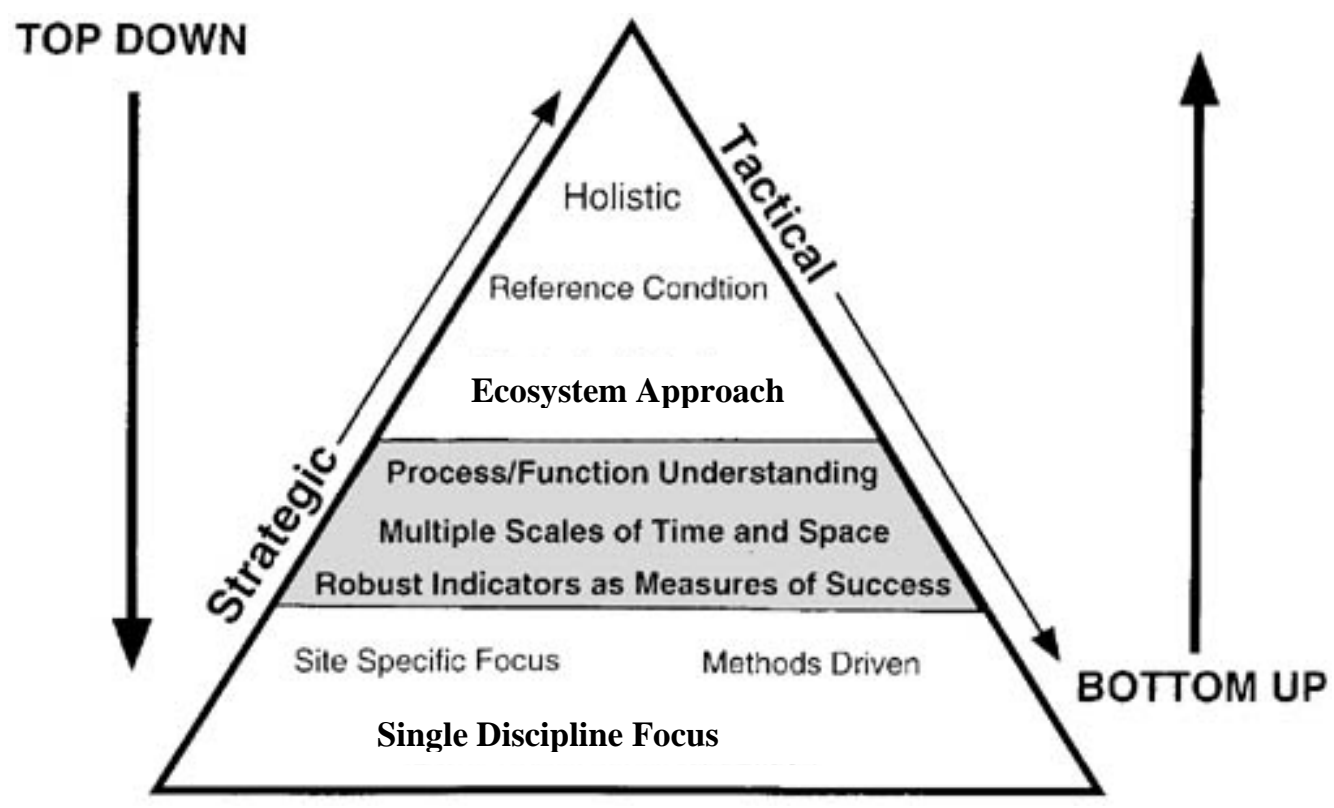


Figure 2. The wooden fort constructed in the Great Meadows by George Washington (British) in 1754 has been replaced with a replica which stands today in the same location for visitors to see. The fort could hold approximately 50 men at the time of battle, and the rest of his troops filled the shallow trenches they had dug around the structure. The French and Native American force attacked George Washington's troops from the line of trees that bordered the meadow and served as shelter from the rain.

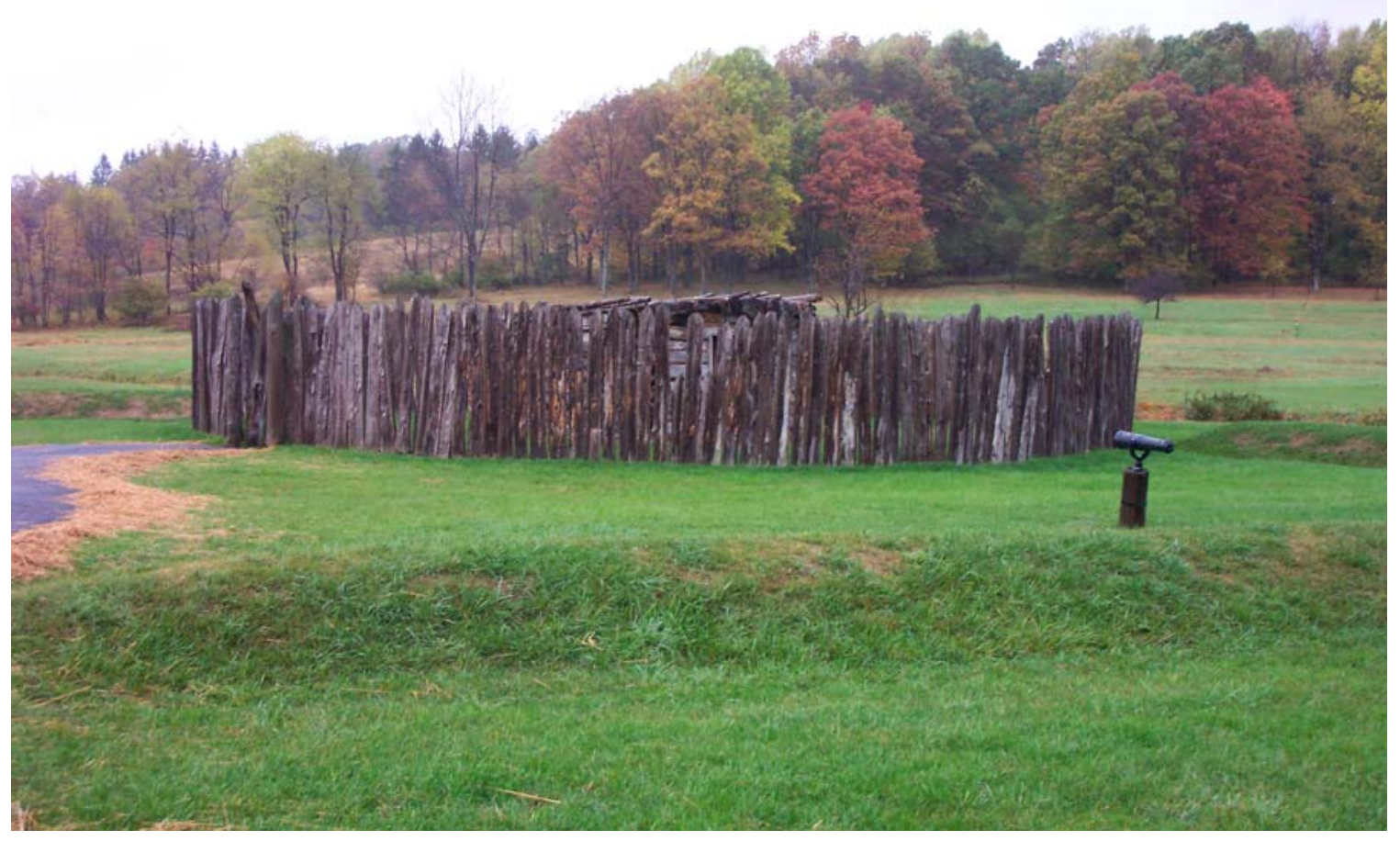


Figure 3. Morrow's honeysuckle (Lonicera morrowii) is a bush honeysuckle with elliptic to oblong gray-green leaves that are pubescent beneath. The leaves are $3-6 \mathrm{~cm}$ long, with white flowers that fade to yellow. The flowers are pubescent, $1.5-2 \mathrm{~cm}$ long and are attached to densely hairy peduncles $5-15 \mathrm{~mm}$ long. The fruits are red and high in carbohydrates (Williams 1999). The shrub reaches a height of $2 \mathrm{~m}$ (Gleason and Cronquist 1991). Twigs of Morrow's honeysuckle are hairy and hollow (Petrides 1972).

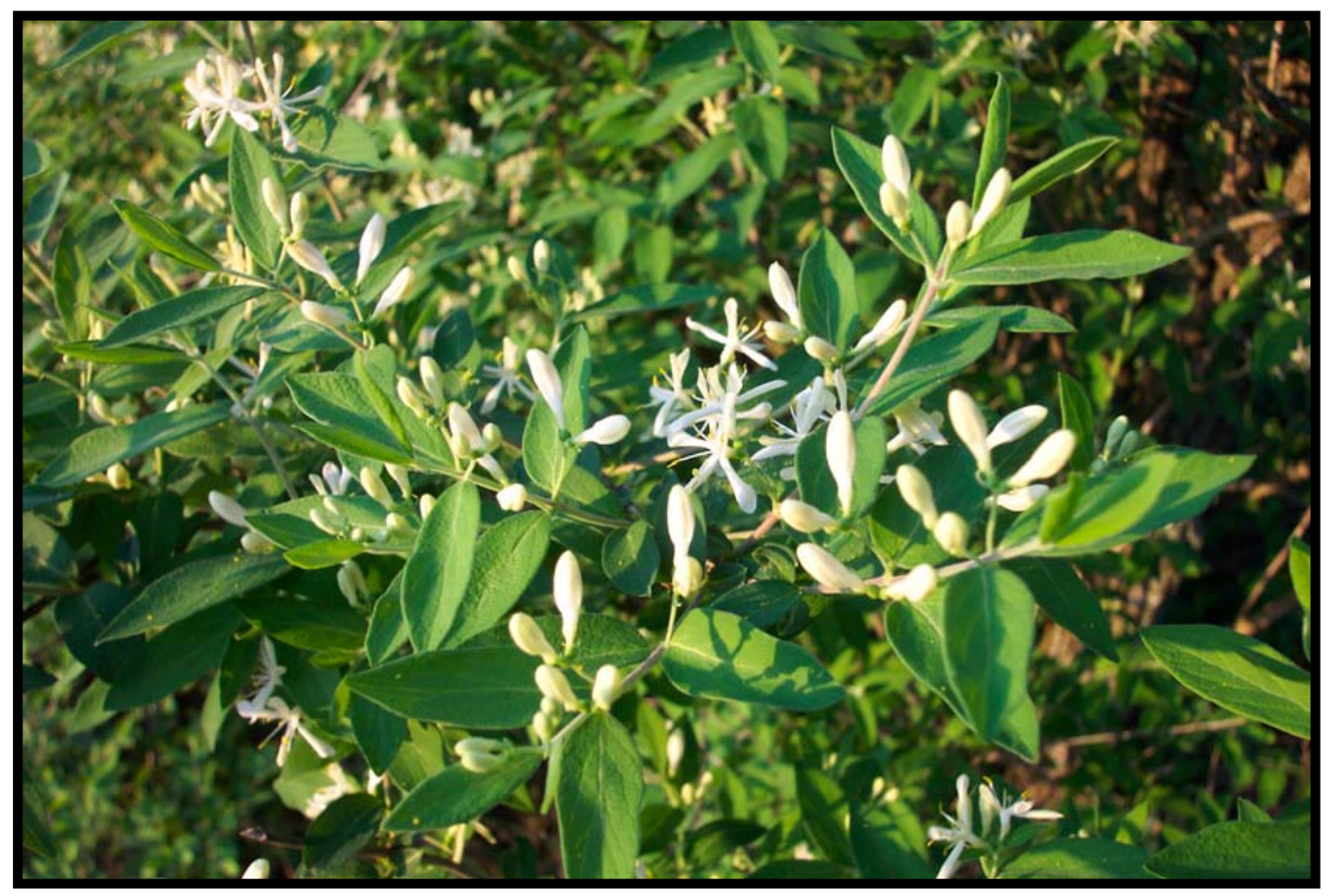


Figure 4. The Fort Necessity National Battlefield in Fayette County, Pennsylvania, USA.

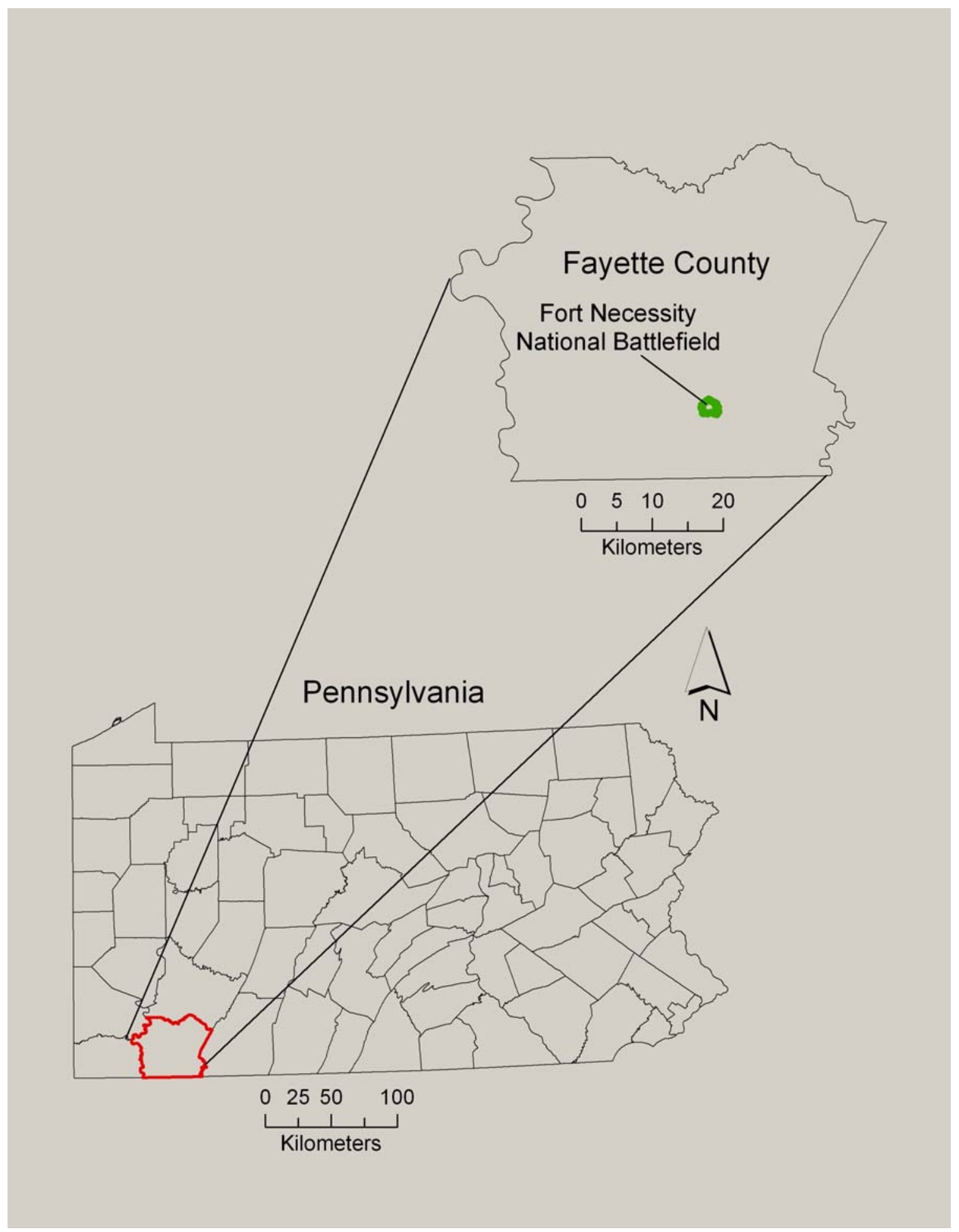


Figure 5. A topographic map of Fort Necessity National Battlefield in Fayette County, Pennsylvania, USA.

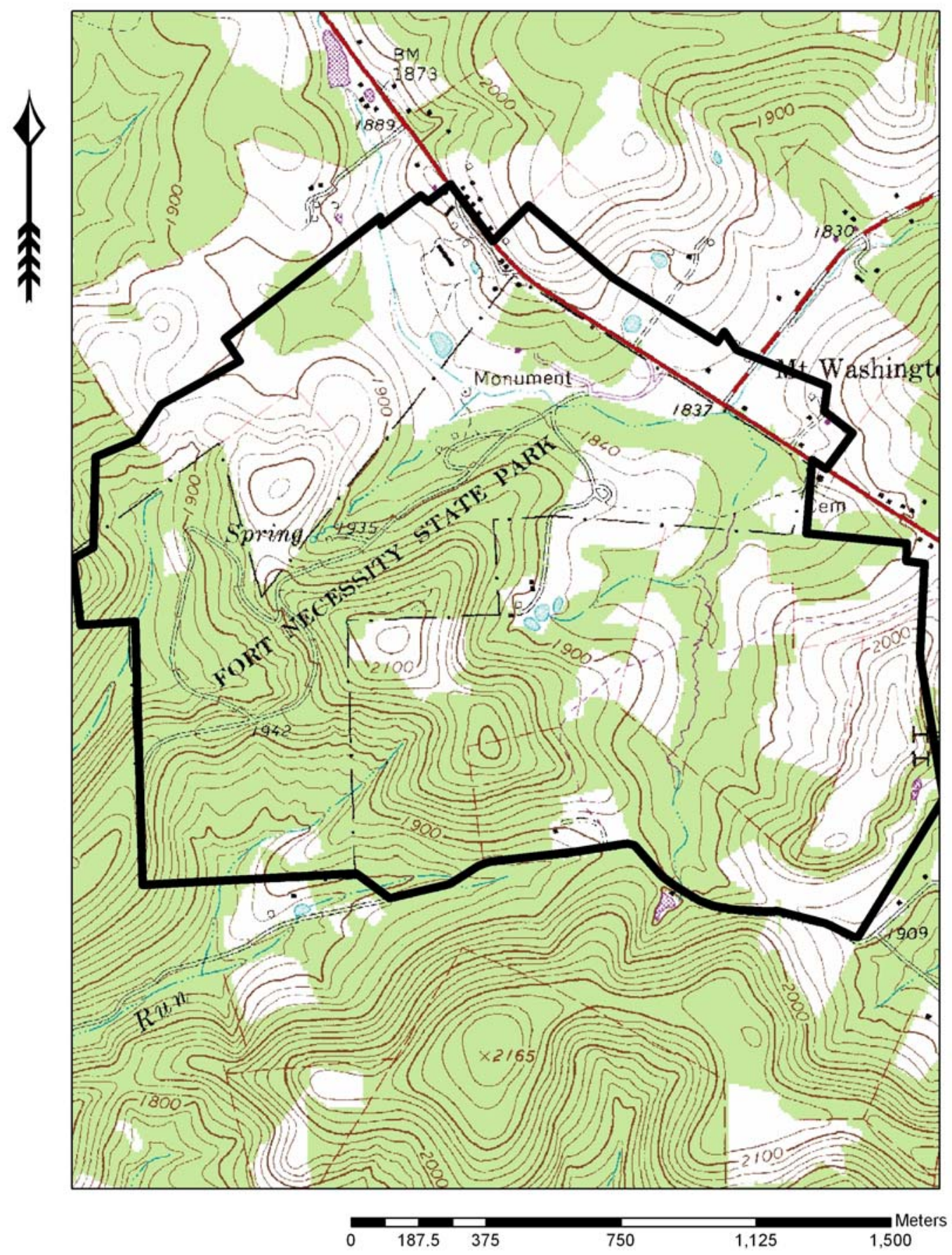


Figure 6. A map depicting the soils at Fort Necessity National Battlefield in Fayette County, Pennsylvania, USA. Soils include the following: Brinkerton and Armagh silt loams (BaB), Cavode silt loams ( $\mathrm{CaC} 2)$, Gilpin channery silt loams ( $\mathrm{GcC} 2)$, and Philo silt loam $(\mathrm{Ph})$.

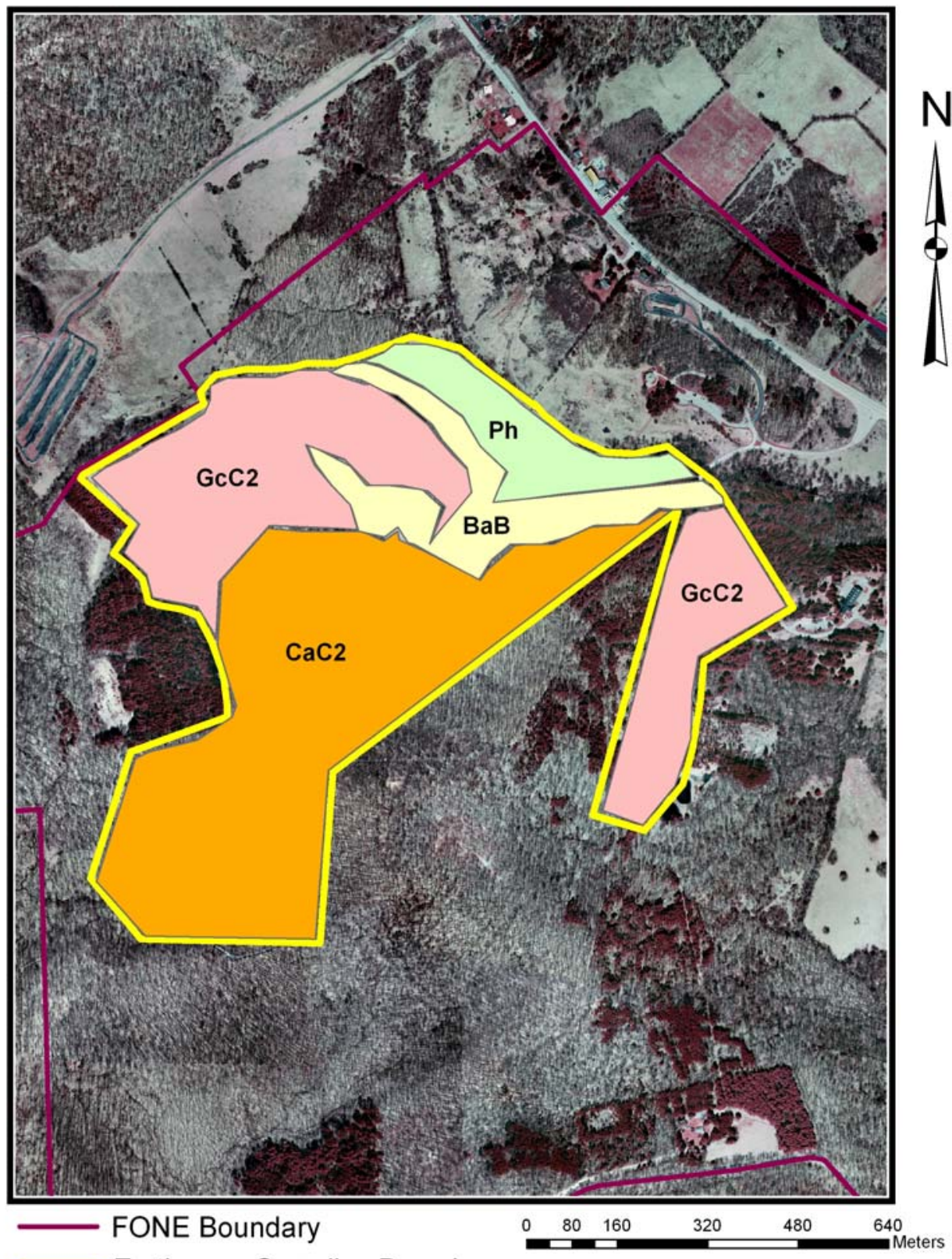

Earthworm Sampling Boundary 


\section{CHAPTER II}

2 November 2005

James T. Anderson

West Virginia University

PO Box 6125

Morgantown, WV 26505-6125

304/293-2941x2445; Fax: 304/293-2441; E-mail: jander25@wvu.edu

RH: Prebaiting effects on small mammal trapping success •Edalgo and Anderson

PREBAITING EFFECTS ON SMALL MAMMAL TRAPPING SUCCESS IN A

\section{MORROW'S HONEYSUCKLE DOMINATED AREA}

Jennifer A. Edalgo, West Virginia University, Division of Forestry, P.O. Box 6125, Morgantown, WV, 26506-6125, USA, jedalgo@mix.wvu.edu

James T. Anderson, West Virginia University, Division of Forestry, P.O. Box 6125, Morgantown, WV, 26506-6125, USA, jander25@wvu.edu

Abstract: Whether or not to include prebaiting in small mammal trapping regimes has had conflicting recommendations in the literature. The effectiveness of prebaiting in an exotic and invasive shrub community, Morrow's honeysuckle (Lonicera morrowii), was tested on $480 \times 120$-m livetrapping grids at Fort Necessity National Battlefield in Fayette County, Pennsylvania from 2004 - 2005. Traps were randomly assigned to 1 of 3 trapping methods: one-third of the traps were prebaited 2 nights $(n=3,508$ trap nights),

This chapter is written in the style of the Wildlife Society Bulletin. 
one-third prebaited 1 night $(n=3,492)$, and one-third had no prebaiting $(n=3,509$ trap nights). We compared small mammal richness, diversity, and relative abundance (no. captures per 100 trap nights) of white-footed mice (Peromyscus leucopus, $n=462$ captures), meadow voles (Microtus pennsylvanicus, $n=89$ captures), meadow jumping mice (Zapus hudsonius, $n=221$ captures), masked shrews (Sorex cinereus, $n=87$ captures), and shorttail shrews (Blarina brevicauda, $n=78$ captures) among prebaited traps and non-prebaited traps, as well as among 4 trapping months (May, June, July, and August). On the first day of trapping as well as all 4 days combined, richness, diversity, and relative abundance for all species were similar among traps that had been prebaited for 2 nights, 1 night, and no prebaiting $(P>0.05)$. Richness and relative abundance (except for white-footed mice and masked shrews) differed $(P<0.001)$ among months for all trap nights combined. These results suggest that prebaiting does not enhance trapping success for small mammals in a landscape dominated by a dense, exotic shrub landscape. The small mammal community fluctuated through the summer months of both years, but this did not affect the trapping success in prebaited traps. We recommend that prebaiting not be employed in attempts to increase trapping success, as no difference in trapping success was recorded in prebaited traps compared to non-prebaited traps.

Key words: capture rates, exotic species, Lonicera morrowii, Microtus pennsylvanicus, Peromyscus leucopus, prebaiting, small mammal, trapping success

Wildlife Society Bulletin 00(0): 000-000

When capturing wildlife, the most time and cost efficient methods need to be used. Researchers desire to know the fastest way to capture the most individuals in a 
given area. Small mammals are commonly captured alive by trapping with small box traps (Morrison 2002). To improve trapping results, some studies suggest prebaiting the traps thus allowing animals to freely take the bait in the trap (Chitty and Kempson 1949, MacCracken et al. 1985, Andersen 1994, Flowerdew et al. 2004). The trap is baited and initially locked in the "open" position (Chitty and Kempson 1949). The next day, the trap is unlocked so that an animal entering the trap can be caught (Chitty and Kempson 1949). The idea behind prebaiting is that animals become more familiar with the new objects (box traps) in their environment and are attracted to the food source, hence they will enter the traps more readily when the traps are set (Chitty and Kempson 1949). Prebaiting has been used to capture ungulates (Taylor 1991), canids (Tietjan and Matschke 1982, Hegglin et al. 2004), primates (Bicca-Marques and Garber 2004), nuisance birds (Palmer 1970), large rodents (Campbell et al. 1981, Williams and Moore 1995), and insects (Waser 1998), however, it has not regularly been used in small mammal trapping (Bowman et al. 2001). Bowman et al. (2001) surveyed 127 published small mammal studies and were surprised to find only 7 articles mentioning prebaiting. Considering the amount of time, money, equipment, and technical assistance trapping takes (Howard 1959) and the fact that various studies continue to add prebaiting into their trapping regimes, there is surprisingly little literature confirming the assumption that prebaiting improves capture rates.

Studies that tested prebaiting reported different conclusions as to its effectiveness at capturing more animals during a given trapping period (Bowman et al. 2001). Chitty and Kempson (1949) found that if prebaiting was used, there was a greater chance for a whole population to become familiar with the traps and larger catches could be expected 
in fewer trapping days. Grodziński et al. (1966) found that the amount of bait consumed in the prebaiting period did not correlate with the number of rodents captured, yet they still recommended employing prebaiting, but shortening the prebaiting period from 7 to 5 days. Zejda and Holišovā (1970) determined that each species responded differently to the particular day they first ingested bait, but most individuals took bait on the second day of prebaiting. Pelikán et al. (1972) found that prebaiting was directly correlated with the catch size, but conclude that prebaiting resulted in an artificial concentration of individuals to the plot and an overestimation of their density. Gurnell (1980) suggested that the prebaiting would only be beneficial if the trapping period was short, on the order of 1 or 2 nights. Sugihara et al. (1995) found that prebaiting enhanced trapping success when they used one type of bait (zinc phosphide oat bait), but not for a different type (zinc phosphide pellet bait). Some studies recommend prebaiting or used prebaiting but offered no evidence for its effectiveness (Moore 1936, Howard 1959, MacCracken et al. 1985, Flowerdew et al. 2004). No studies that tested prebaiting caught Peromyscus spp., the most common wild rodent across the United States (Merritt 1987).

One of the most invasive and threatening plants to disturbed land in the eastern United States is the bush honeysuckle (Lonicera spp.), particularly Morrow's honeysuckle (L. morrowii) (Nyboer 1992). Studies are lacking that examine effects of exotic plants on small mammal communities, yet current research suggests that exotic plant invasions have a high potential to alter small mammal ecology (Pearson et al. 2001). Few studies on small mammals have been conducted in areas with bush honeysuckle on site (Anthony et al. 1981, McCay and Storm 1997, Williams 1999), and we did not find any studies that have been conducted with Morrow's honeysuckle on-site. 
The shrubs have been promoted for decades for their wildlife, shelterbelt, and ornamental value, but new information has shown that they can have many negative impacts including: impeding forest regeneration, reducing the richness and cover of herb communities, and providing less nutritious fruits than native fruit-bearing shrubs (i.e. Viburnum spp.) (Williams 1999). As Morrow's honeysuckle out-competes and replaces native vegetation, the wildlife in the area lose their natural habitat (Western Pennsylvania Conservancy, unpublished report). The composition of the small mammal community in an invasive shrub habitat should be understood because of a reciprocal relation where small mammals play an important role in dispersing exotic plant seeds (Williams 1999), but exotic plant invasions may modify the ecological roles of the small mammals (Pearson et al. 2001).

We hypothesize that prebaiting will improve trapping success compared to traps that are not prebaited; additionally, traps that are prebaited for 2 nights will capture more small mammals than the traps that are prebaited for 1 night. We predict that traps with evidence of bait being eaten in the prebaiting stage, will be the traps that small mammals also will enter during the trapping stage. The objectives used to assess this hypothesis are to:

1) Determine the amount of use the traps are getting during the prebaiting stage when the traps are secured in the "open" position;

2) Determine small mammal species richness, species diversity, and relative abundance within exotic Morrow's honeysuckle; and 
3) Compare the richness, diversity, and relative abundance of small mammals caught among the prebaited traps and the non-prebaited traps, as well as by year and month, and to quantify the effectiveness of prebaiting.

\section{Study Area}

The study was conducted on the 390-ha Fort Necessity National Battlefield (FONE) in Fayette County, Pennsylvania, USA (Figure 1) with elevations ranging from $535-710 \mathrm{~m}$ (National Park Service 1991). The average annual temperature is $9^{\circ} \mathrm{C}$ and the average annual precipitation is $119 \mathrm{~cm}$; annual snowfall is greater than $39 \mathrm{~cm}$ (National Park Service 1991). Soils include moderately deep, moderate to well drained, and medium-textured soils underlain by acidic shale and sandstone bedrock (National Park Service 1991).

Trapping occurred in the upland areas where the current composition of vegetation has been extensively disturbed and invaded by non-native species (The Western Pennsylvania Conservancy, unpublished report). Morrow's honeysuckle envelops the upland sites (National Park Service 1991) (Figure 2; Appendix IIb); our small mammal grids called "Nursery," "Fort," "Upland," and "Zoo" were located in the most densely covered areas of the Morrow's honeysuckle invasion at FONE (Figure 3).

\section{Methods}

We trapped in April, May, June, and August of 2004 and in May, June, and July of 2005 on 2 sites (Figure 3). We established 2 grids per site. We used a grid pattern of 10 transects with 15 traps on each line spaced at 8 -m intervals $(80 \times 120 \mathrm{~m}$ grids $)$. We established a total of 600 trapping stations within the 4 grids. At each trapping station we 
set a collapsible Sherman live trap (small folding galvanized, $5 \times 6.4 \times 16.5 \mathrm{~cm}$, H.B.

Sherman Traps, Tallahassee, Florida).

We randomly assigned each trap to 1 of 3 treatments during each trapping period. We prebaited one-third of the traps for 2 nights, one-third 1 night, and one-third we did not prebait during each month. Four days of trapping immediately followed the treatments whereupon all of the traps were checked and then re-set from $0600-1000 \mathrm{hrs}$. All traps were set to begin capturing animals on the same day. Traps were baited with peanut butter and rolled oats wrapped with wax paper (D. O’Dell, University of Arizona, personal communication). When we captured a small mammal, we used a quart-sized plastic bag to hold the animal while recording the following data and measurements: date and time of processing, species, total length, tail length, right ear length, right hindfoot length, mass, age (adult or juvenile), sex, reproductive condition (female: inactive, active, lactating, or pregnant; male: abdominal or testes length), and trap location (McDiarmid and Wilson 1996). We tagged every mouse and vole with a \#1005-1 monel ear tag (National Band and Tag Company, Newport, Kentucky 41072-0430) because all mice and voles on the sites had ear pinnae large enough to support the tag. We toe-clipped shrews and released them where they were caught (Silvy et al. 2005). We subtracted 0.5 trap nights per sprung trap to account for traps that were closed but did not contain captures (Beauvais and Buskirk 1999).

\section{Statistical Analysis}

We performed G-tests of independence with William's correction factor on the number of captures for traps prebaited for 1 night, 2 nights, or no nights to determine whether capture heterogeneity existed among prebaiting methods (Sokal and Rohlf 
1995). This $G$-test was conducted on the first day of captures alone as well as on all 4 days of captures combined. We also calculated the percentage of traps that showed evidence of animals entering them on the first night when one-third of the traps were prebaited, and then on the second night when a total of two-thirds of the traps were prebaited.

We used the Simpson's Index of Diversity $\left\{D=1-\left[\sum\left(n_{\mathrm{i}}\left[n_{\mathrm{i}}-1\right]\right) /(N[N-1])\right]\right\}$ to calculate diversity (Magurran 1988). We computed diversity based on the total number of individuals captured per species for each trapping method in each month. For both the first day of actual trapping and then all 4 days of trapping combined, we used a repeated measures analysis of variance to account for multiple observations on the same trap stations collected at different times ( $n=7$ months) from 2004 - 2005 (PROC GLM; SAS Inst. Inc. 2003). Dependent variables: 1) total relative abundance (number of total individuals captured per 100 trap nights) of abundant (i.e., > 50 captures) small mammals, 2) species richness (number of species captured per ha on each plot), and 3) diversity were compared against the independent variable, trapping method (1 night prebait, 2 nights prebait, and no prebait). We used Duncan's multiple means comparison to separate means (SAS Inst. Inc. 2003). The dependent variables were not significantly different among years at the 0.01 alpha level and therefore, we used months alone to test for temporal variation among the dependent variables (PROC GLM; SAS Inst. Inc. 2003).

We checked data for normality with Shapiro-Wilk Statistic (PROC UNIVARIATE; SAS Inst. Inc. 2003). We checked all dependent variables against the independent variable trap method for homogeneity of variances using Levene's Test for 
Homogeneity; none of the variances were significantly different $(P>0.05$; SAS Inst. Inc. 2003). We used the following transformations to achieve normality: arcsine square-root, $\log$, and rank. We present all data as untransformed values. The individual trap served as the experimental unit. An alpha level of 0.05 was used for all tests.

\section{Results}

Total trap nights (TN) would have equaled 13,200, but due to raccoon (Procyon lotor) tampering, some traps (May 2004 lost 30 TN, Jun 2004 lost 449 TN, Aug 2004 lost 40 TN, May 2005 lost 221 TN, Jun 2005 lost 589 TN, Jul 2005 lost 162 TN) were not available for use. We excluded April trapping nights (1,200 trap nights) from 2004 analyses because no animals were captured; we believe that the small mammals were not active yet. We used the Beauvais and Buskirk (1999) correction for sprung traps and this left us with 11,255 TN. Trapping efforts resulted in 973 total captures of 485 unique individuals representing 10 species (Table 1). The most abundant species included: white-footed mice (Peromyscus leucopus), meadow jumping mice (Zapus hudsonius), meadow voles (Microtus pennsylvanicus), masked shrews (Sorex cinereus), and shorttail shrews (Blarina brevicauda).

The number of total captures on the $1^{\text {st }}$ day of trapping $(n=281$ captures $)$ did not differ $\left(G_{3}=3.207, P>0.05\right)$ among prebaiting methods (Appendix IIa). The number of total captures $(n=973)$ did not vary $\left(G_{3}=4.678, P>0.05\right)$ among traps prebaited 1 night ( $n=1,017$ traps), 2 nights $(n=976$ traps), or no nights prebaited ( $n=1,002$ traps). Of the traps that were prebaited for 2 nights, $22.4 \%$ showed evidence of animals entering them and bait being eaten on the first night; $24.3 \%$ of the traps showed similar evidence on the second night. Overall, $11.3 \%$ of the traps that we prebaited for 2 nights showed evidence 
of animals entering them on both nights. For all of the traps in 2004 and 2005 that we prebaited for 1 night, $23.0 \%$ showed evidence of animals entering the trap.

For the first day of trapping, richness, diversity, and relative abundances did not differ among trapping methods $\left(F_{2,15}=0.16, P=0.856\right)$ or months (Wilks' $\lambda=0.350, P$ $=0.055)$ and there was no interaction between treatment and months (Wilks' $\lambda=0.633, P$ $=0.934)$ in the repeated measures ANOVA. For all 4 trapping days combined, there was also no differences among trapping methods $\left(F_{2,15}=0.05, P=0.948\right)$ and there was no interaction between treatment and months (Wilks' $\lambda=0.511, P=0.764$ ) for species richness, diversity, and relative abundance (Table 2); however, the months main effect differed (Wilks' $\lambda=0.002, P<0.001$ ) among the dependent variables (Table 3 ). The total species richness in May was $42 \%, 39 \%$, and $35 \%$ lower $\left(F_{3,17}=5.31, P=0.012\right)$ than in June, July, or August respectively. Among months, no differences existed in diversity $\left(F_{3,17}=1.32, P=0.308\right)$ or relative abundance of white-footed mice $\left(F_{3,17}=\right.$ $1.91, P=0.175)$, meadow voles $\left(F_{3,17}=1.69, P=0.214\right)$, or masked shrews $\left(F_{3,17}=0.74\right.$, $P=0.546$ ). The relative abundance of meadow jumping mice was $81 \%, 54 \%$, and $69 \%$ greater $\left(F_{3,17}=6.58, P=0.005\right)$ in August than in May, June, or July respectively. The relative abundances of shorttail shrews in May and June were lower $\left(F_{3,17}=11.21, P<\right.$ 0.001) than in July and August, but June did not differ from August.

\section{Discussion}

Our investigation indicates that prebaiting does not enhance trapping success for small mammals in a relatively homogenous landscape. We had good trapping success in that by the fourth trapping night in all months, most animals (61\%) were recaptures. We recommend that prebaiting not be employed in attempts to increase trapping success, as 
no difference in trapping success was recorded in prebaited traps compared to nonprebaited traps. Prebaiting did not appear to enhance trapping success on the first day of trapping, nor by the $4^{\text {th }}$ day of trapping. Although Gurnell (1980) and Grodziński et al. (1966) captured different species than we did, our results agree with theirs in that no correlation was found between the number of rodents captured and the effect of prebaiting. Our recommendations differ with those of Grodziński et al. (1966); they suggested shortening the prebaiting and trapping nights from 7 nights each to 5 nights each. Although our goals were similar, to perfect small mammal population estimation by using the most exact and economical methods, we disagree with Grodziński et al.'s (1966) interpretation of a similar finding and we assert that the least laborious and most effective means to trap small mammals is to abandon prebaiting altogether.

We caution researchers and managers who trap small mammals in early May that the species richness may be much lower than later in the season. Specifically, meadow jumping mice hibernate for 8 months out of the year and may not have been active in May 2004 (Boonstra and Hoyle 1986). The relative abundance of meadow voles and meadow jumping mice fluctuated throughout the summer months of 2004 and 2005, without a clear trend of gradually increasing or decreasing through each year. Our results for the relative abundance of white-footed mice agree with Lewellen and Vessey (1998) who found that their population peaks in the late summer with the increase in young animals, relative to annual lows in the early spring. The low population densities in early spring may also have been due to lack of food and the cold temperatures in the winter (Lewellen and Vessey 1998). The small mammal community fluctuated through the summer months each year, but this did not affect the trapping success in prebaited traps. 
A possibility exists that prebaiting does enhance trapping success, but it was not detected with our trapping design. Animals that entered the prebaited traps may have only become familiar with the trap itself, and not the location and microhabitat characteristics associated with the prebaited trap. Animals that visited a trap in the prebaiting period may not have been captured in that exact trap during the trapping period; the animals visiting prebaited traps may have been captured in any open trap during the trapping period. If this possibility was true, that animals become familiar with the trap as an object rather than the specific trap and location, then they are more likely to enter any trap afterward. Furthermore, only a fraction of the total traps would need to be prebaited. Perhaps a different trapping design would help to discern this potential effect, or if individuals could be marked in the prebaiting period, then their trap fidelity would be known. We suggest that a future study could mark each prebaited trap with a unique color of fluorescent powder and then monitor whether the unique colors were found in other traps; this would determine the extent of loyalty to one trap location.

Similar to Gurnell's (1980) study, we had quite a few deaths throughout the duration of the study in 2004 and 2005. Combined deaths totaled 165 individuals (17\% of total captures died), shrews (Soricidae) represented $63.0 \%$ of the mortalities $(n=104$ shrew deaths). Shrews, which are insectivores, readily enter traps without the presence of insects and then will die of starvation within a few hours of capture (Little and Gurnell 1989). Although these animals were unavailable for capture after death, we believe that the effect of prebaiting on trapping success was shown because the animals that died did have a chance to visit the prebaited traps and then also had at least one chance (on the first day of trapping) to be captured before they died. Furthermore, we did not detect any 
differences in trapping success among prebaiting methods on the $1^{\text {st }}$ day of trapping. One suggestion for reducing the animal mortality would be to trap for fewer than 4 nights; "trap-happy" animals that had been captured 3 or 4 consecutive nights may have withstood long hours in the trap and by the third or fourth trapping night, they had used up their reserve energy (Monimeau et al. 2002). Considering that masked shrews are

active diurnally (Moore 1949), another suggestion we have for reducing deaths would be to close the traps when they are checked at $0600-1000 \mathrm{hrs}$ and then reset the traps each day at $1700-2000 \mathrm{hrs}$; however, more resources (e.g., time, money, equipment, technical assistance) would be needed to revisit the site every day (Howard 1959).

\section{Management Implications}

Our response to Zejda and Holišovā's (1970) remark wondering "whether prebaiting is necessary at all," would be that prebaiting is not necessary to sufficiently sample the small mammal community. Any study that involves trapping small mammals is relatively costly in labor and the most efficient techniques need to be understood (Chitty and Kempson 1949). We do not recommend trapping for fewer than 4 days because by our fourth trapping day we still had 39\% of the animals were new captures. In our opinion, using 4 trapping days without prebaiting would yield sufficient and reliable density estimates, and adding prebaiting would only affix a greater cost to the project.

Acknowledgments. This work was funded by the National Park Service and Fort Necessity National Battlefield in Farmington, Pennsylvania. We thank Connie A. Ranson and John W. Edwards for reviewing this manuscript. Jason Love, Mark Hepner, Jason Alexander, Jennifer Love, and Robbie Edalgo from West Virginia University 
(WVU) assisted with field work. We appreciate the help from George Seidel for statistical guidance. This is scientific article number XXXX of the WVU Agricultural and Forestry Experimental Station. The WVU Animal Care and Use Committee (ACUC) approved our animal handling protocols (04-0104).

\section{LITERATURE CITED}

Andersen, D. C. 1994. Demographics of small mammals using anthropogenic desert riparian habitat in Arizona. Journal of Wildlife Management 58:445-454.

Anthony, R. G, L. J. Niles, and J. D. Spring. 1981. Small-mammal associations in forested and old-field habitats-a quantitative comparison. Ecology 62:955-963.

Beauvais G. P. and S. W. Buskirk. 1999. Modifying estimates of sampling effort to account for sprung traps. Wildlife Society Bulletin 27:39-43.

Bicca-Marques, J. C. and P. A. Garber. 2004. Use of spatial, visual, and olfactory information during foraging in wild nocturnal and diurnal anthropoids: a field experiment comparing Aotus, Callicebus, and Sanguinus. American Journal of Primatology 62:171-187.

Boonstra, R. and J. A. Hoyle. 1986. Rarity and coexistence of a small hibernator, Zapus hudsonius, with fluctuating populations of Microtus pennsylvanicus in the grasslands of southern Ontario. Journal of Animal Ecology 55:773-784.

Bowman, J., C. V. Corkum, G. J. Forbes. 2001. Spatial scales of trapping in smallmammal research. Canadian Field Naturalist 115:472-475. 
Campbell, D. L., G. D. Lindsay, J. Evans, S. R. Olmstead, and L. E. Johnson. 1981. Evaluation of zinc phosphide, strychnine alkaloid, and RH 787 (VacorR) rodenticides for controlling mountain beavers in forest clearcuts. U.S. Fish and Wildlife Service, Denver Wildlife Research Center, Job Completion Report, Olympia, Washington, USA.

Chitty, D. and D. A. Kempson. 1949. Prebaiting small mammals and a new trap design of live trap. Ecology 30:536-542.

Flowerdew, J. R., R. F. Shore, S. M. C. Poulton, and T. H. Sparks. 2004. Live trapping to monitor small mammals in Britain. Mammal Review 34:31-50.

Grodziński, W., Z. Pucek, and L. Ryszkowski. 1966. Estimation of rodent numbers by means of prebaiting and intensive removal. Acta Theriologica 6:297-314.

Gurnell, J. 1980. The effects of prebaiting live traps on catching woodland rodents. Acta Theriologica 25:255-264.

Hegglin, D., F. Bontadina, S. Gloor, J. R. Swild, U. Muller, U. Breitenmoser, and P. Deplazes. 2004. Baiting red foxes in an urban area: a camera trap study. Journal of Wildlife Management 68:1010-1017.

Howard, W. E. 1959. How to overcome bait shyness in rodents. Pest Control 27:913.

Lewellen, R. H. and S. H. Vessey. 1998. The effects of density dependence and weather on population sixe of a polyvoltine species. Ecological Monographs 68:571-594.

Little, J, and J. Gurnell. 1989. Shrew capture and rodent field studies. Journal of Zoology 218:329-331. 
MacCracken, J. G., D. W. Uresk, and R. M. Hansen. 1985. Rodent-vegetation relationships in southeastern Montana. Northwest Science 59:272-278.

Magurran, A. E. 1988. Ecological diversity and its measurement. Princeton University Press. Princeton, New Jersey, USA.

McCay, T. S. and G. L. Storm. 1997. Masked shrew (Sorex cinereus) abundance, diet and prey selection in an irrigated forest. American Midland Naturalist 138:268275.

McDiarmid, R. W. and D. E. Wilson. 1996. Data standards. Pages 56-60 in D. E. Wilson, F. R. Cole, J. D. Nichols, R. Rudran, and M. S. Foster, editors. 1996. Measuring and monitoring biological diversity. Smithsonian Institution Press. Washington, D.C., USA.

Merritt, J. F. 1987. Mammals of Pennsylvania. University of Pittsburgh Press, Pittsburgh, Pennsylvania, USA.

Monimeau, L., D. Mouillot, R. Fons, R. Prodon, B. Marchand. 2002. Impact of prescribed burning on the survival rates of the wood mouse (Apodemus sylvaticus). Acta Oecologica 23:51-58.

Moore, A. W. 1936. Improvements in live trapping. Journal of Mammalogy 17:372374.

Moore, J. C. 1949. Notes on the shrew, Sorex cinereus, in the southern Appalachians. Ecology 30:234-237.

Morrison, M. L. 2002. Sampling methods: Wildlife Restoration. Island Press, Washington, D.C., USA. 
National Park Service. 1991. General Management Plan/Development Concept Plan/Interpretive Prospectus: Fort Necessity National Battlefield. U. S. Department of the Interior Prepared by the Denver Service Center, Denver, Colorado, USA.

Nyboer, R. 1992. Vegetation management guideline: bush honeysuckles - tatarian, Morrow's, Belle, and Amur honeysuckle (Lonicera tatarica L., L. morrowii Gray, L. x bella Zabel, and L. maackii [Rupr.] Maxim.). Natural Areas Journal 12:218219.

Palmer, T. K. 1970. House Finch (Linnet) control in California. Pages 172-178 in Vertebrate Pest Conference Proceedings: Fourth Vertebrate Pest Conference, Lincoln, Nebraska, USA.

Pearson, D. E., Y. K. Ortega, K. S. McKelvey, and L. F. Ruggiero. 2001. Small mammal communities and habitat selection in northern Rocky Mountain Bunchgrass: implications for exotic plant invasions. Northwest Science 75:107117.

Pelikán, J., J. Zejda, and V. Holišovā. 1972. Influence of prebaiting on the catch of small mammals. Zoologickē Listy 21:209-225.

SAS Institute, Inc. 2003. Statistical analysis system: user's guide. Version 9.1. SAS Institute Inc., Cary, North Carolina, USA.

Silvy, N. J., R. R. Lopez, and M. J. Peterson. 2005. Wildlife marking techniques. Sixth edition. Pages 339-376 in C. E. Braun, editor. Techniques for wildlife investigations and management. The Wildlife Society, Bethesda, Maryland, USA. 
Sokal, R. R. and F. J. Rohlf. 1995. Biometry. Third edition. W. H. Freeman and Company, New York, New York, USA.

Sugihara, R. T., M. E. Tobin, and A. E. Koehler. 1995. Zinc phosphide baits and prebaiting for controlling rats in Hawaiian sugarcane. Journal of Wildlife Management 59:882-889.

Taylor, R. 1991. The feral hog in Texas, Federal Aid Report Series No. 28. Texas Parks and Wildlife Department, Austin, Texas, USA.

Tietjen, H. P. and J. H. Matschke. 1982. Aerial prebaiting for management of prairie dogs with zinc-phosphide. Journal of Wildlife Management 46:1108-1112.

Waser, N. M. 1998. Task-matching and short-term size shifts in foragers of the harvester ant, Messor pergandei (Hymenoptera: Formicidae). Journal of Insect Behavior 11:451-462.

Williams, C. E. 1999. Fruits of alien shrubs and deer mice: a test of the persistent fruit defense hypothesis. Journal of the Pennsylvania Academy of Science 73:33-37.

Williams, C. K. and R. J. Moore. 1995. Effectiveness and cost-efficiency of control of the wild rabbit, Oryctolagus cuniculus (L.), by combinations of poisoning, ripping, fumigation and maintenance fumigation. Wildlife Research 22:253-269.

Zejda, J. and V. Holišovā. 1970. On the prebaiting of small mammals in the estimation of their abundance. Zoologickē Listy 19:103-118. 
Table 1. Mammalian species captured (total number of captures and number of unique individuals) at Fort Necessity National Battlefield in Fayette County, Pennsylvania, USA from $2004-2005$.

\begin{tabular}{|c|c|c|c|}
\hline & & Total & Unique \\
\hline Common name & Scientific Name & Captures & Individuals \\
\hline White-footed mouse & Peromyscus leucopus & 462 & 131 \\
\hline Meadow jumping mouse & Zapus hudsonius & 221 & 130 \\
\hline Meadow vole & Microtus pennsylvanicus & 89 & 55 \\
\hline Masked shrew & Sorex cinereus & 87 & 80 \\
\hline Shorttail shrew & Blarina brevicauda & 78 & 64 \\
\hline Woodland jumping mouse & Napaeozapus insignis & 25 & 17 \\
\hline Eastern chipmunk & Tamias striatus & 7 & 5 \\
\hline Southern bog lemming & Synaptomys cooperi & 2 & 2 \\
\hline Deer mouse & Peromyscus maniculatus & 1 & 1 \\
\hline Red squirrel & Tamiasciurus hudsonicus & 1 & 1 \\
\hline
\end{tabular}


Table 2. Species richness, Simpson's index of diversity, and relative abundance (total individuals captured per 100 trap nights) based on captures during 4 nights for 3 prebaiting methods on 4 trapping grids dominated by Morrow's honeysuckle (Lonicera morrowii) at Fort Necessity National Battlefield in Fayette County, Pennsylvania, USA in 2004 and 2005.

\begin{tabular}{|c|c|c|c|c|c|c|}
\hline \multirow[b]{3}{*}{ Dependent variable ${ }^{\mathrm{a}}$} & \multicolumn{6}{|c|}{$\begin{array}{l}\text { No. nights } \\
\text { prebaited }^{b}\end{array}$} \\
\hline & \multicolumn{2}{|c|}{2 Nights } & \multicolumn{2}{|c|}{1 Night } & \multicolumn{2}{|c|}{0 Nights } \\
\hline & $\overline{\mathrm{x}}$ & SE & $\overline{\mathrm{x}}$ & SE & $\overline{\mathrm{x}}$ & SE \\
\hline Species Richness & $1.387 \mathrm{~A}$ & 0.145 & $1.387 \mathrm{~A}$ & 0.198 & $1.343 \mathrm{~A}$ & 0.206 \\
\hline Simpson's index of diversity & $0.655 \mathrm{~A}$ & 0.053 & $0.580 \mathrm{~A}$ & 0.041 & $0.628 \mathrm{~A}$ & 0.077 \\
\hline \multicolumn{7}{|l|}{ Relative abundance } \\
\hline White-footed mouse & $4.167 \mathrm{~A}$ & 1.014 & $5.667 \mathrm{~A}$ & 1.626 & $4.333 \mathrm{~A}$ & 1.202 \\
\hline Meadow jumping mouse & $2.000 \mathrm{~A}$ & 0.683 & $2.000 \mathrm{~A}$ & 0.730 & $1.667 \mathrm{~A}$ & 0.667 \\
\hline Meadow vole & $0.833 \mathrm{~A}$ & 0.307 & $0.833 \mathrm{~A}$ & 0.307 & $1.167 \mathrm{~A}$ & 0.477 \\
\hline Masked shrew & $0.667 \mathrm{~A}$ & 0.211 & $0.833 \mathrm{~A}$ & 0.307 & $1.167 \mathrm{~A}$ & 1.367 \\
\hline Shorttail shrew & $1.000 \mathrm{~A}$ & 0.447 & $0.500 \mathrm{~A}$ & 0.224 & $0.833 \mathrm{~A}$ & 0.401 \\
\hline
\end{tabular}

\footnotetext{
${ }^{\mathrm{a}}$ Values were calculated from untransformed dependent variables.

${ }^{\mathrm{b}}$ The same letter following means in a row indicates no difference $(P>0.05)$ according to Duncan's Multiple Range Test.
} 
Table 3. Species richness, Simpson's Index of Diversity, and relative abundance (total individuals captured per 100 trap nights) for 4 months at Fort Necessity National Battlefield in Fayette County, Pennsylvania, USA in 2004 and 2005.

\begin{tabular}{|c|c|c|c|c|c|c|c|c|}
\hline \multirow[b]{3}{*}{ Dependent variable } & \multicolumn{4}{|c|}{ Trapping } & \multicolumn{4}{|l|}{ period $^{\mathrm{a}}$} \\
\hline & \multicolumn{2}{|c|}{ May } & \multicolumn{2}{|l|}{ June } & \multicolumn{2}{|c|}{ July } & \multicolumn{2}{|c|}{ Aug. } \\
\hline & $\overline{\mathrm{x}}$ & SE & $\overline{\mathrm{x}}$ & SE & $\overline{\mathrm{x}}$ & SE & $\overline{\mathrm{x}}$ & SE \\
\hline Richness & $0.953 \mathrm{~A}$ & 0.173 & $1.647 \mathrm{~B}$ & 0.087 & $1.560 \mathrm{~B}$ & 0.150 & $1.473 \mathrm{~B}$ & 0.173 \\
\hline Diversity & $0.533 \mathrm{~A}$ & 0.077 & $0.648 \mathrm{~A}$ & 0.022 & $0.677 \mathrm{~A}$ & 0.103 & $0.687 \mathrm{~A}$ & 0.022 \\
\hline \multicolumn{9}{|l|}{ Relative abundance } \\
\hline White-footed mouse & $2.763 \mathrm{~A}$ & 0.443 & $6.337 \mathrm{~A}$ & 1.778 & $5.927 \mathrm{~A}$ & 1.521 & $3.003 \mathrm{~A}$ & 0.322 \\
\hline Meadow jumping mouse & $0.915 \mathrm{~A}$ & 0.413 & $1.938 \mathrm{~A}$ & 0.558 & $1.357 \mathrm{~A}$ & 0.268 & 4.113B & 0.387 \\
\hline Meadow vole & $0.918 \mathrm{AB}$ & 0.269 & $0.867 \mathrm{AB}$ & 0.239 & $1.567 \mathrm{~A}$ & 0.712 & $0.337 \mathrm{~B}$ & 0.112 \\
\hline Masked shrew & $0.458 \mathrm{~A}$ & 0.229 & $0.652 \mathrm{~A}$ & 0.405 & $1.367 \mathrm{~A}$ & 0.444 & $0.593 \mathrm{~A}$ & 0.088 \\
\hline Shorttail shrew & $0.070 \mathrm{~A}$ & 0.048 & $1.670 \mathrm{AB}$ & 30.165 & $1.753 \mathrm{C}$ & 0.615 & $1.357 \mathrm{BC}$ & 0.113 \\
\hline
\end{tabular}

\footnotetext{
${ }^{a}$ The same letter following means in a row indicates no difference $(P>0.05)$ according to Duncan's Multiple Range Test.
} 


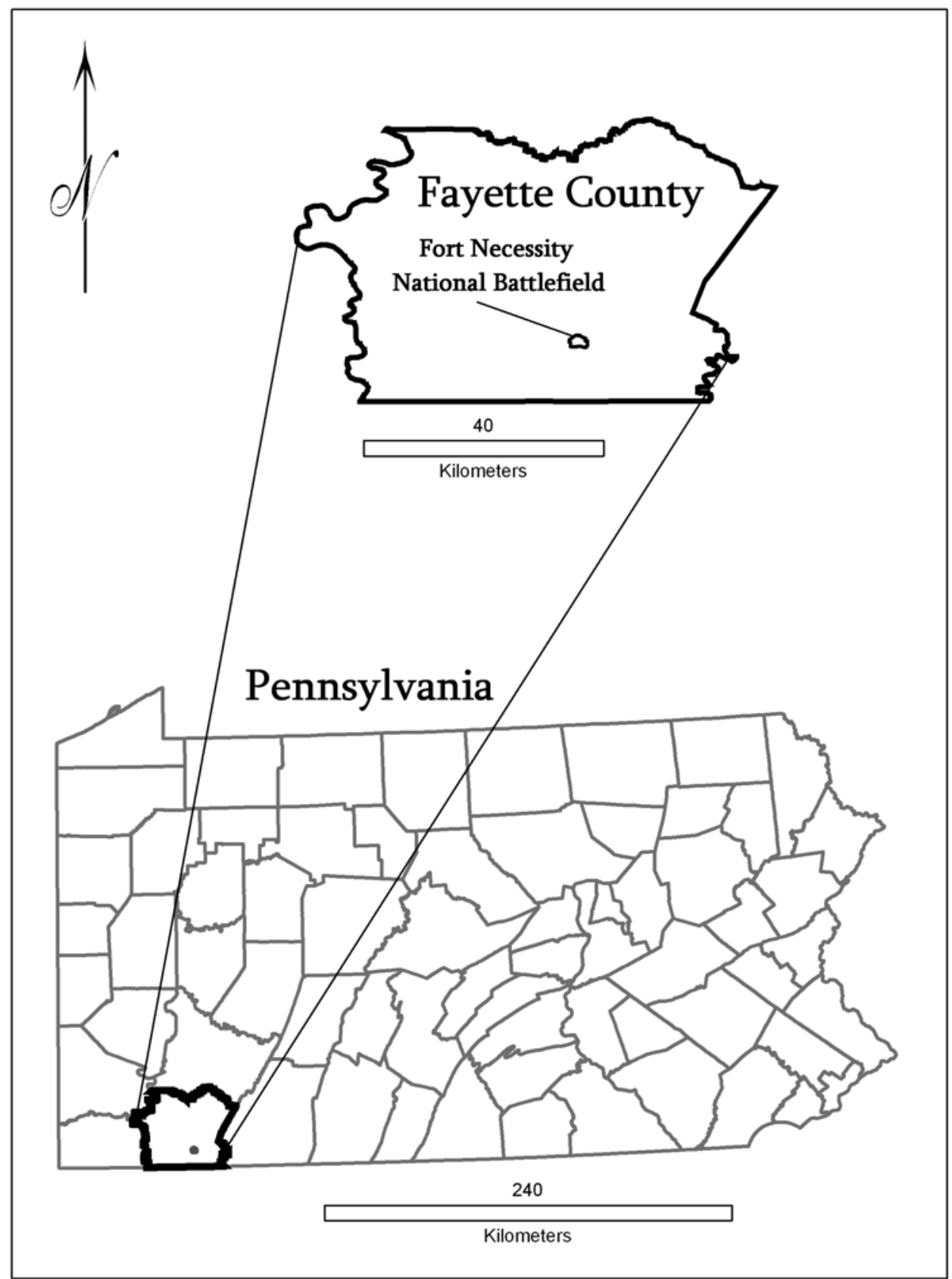

Figure 1. The Fort Necessity National Battlefield in Fayette County, Pennsylvania, USA. 


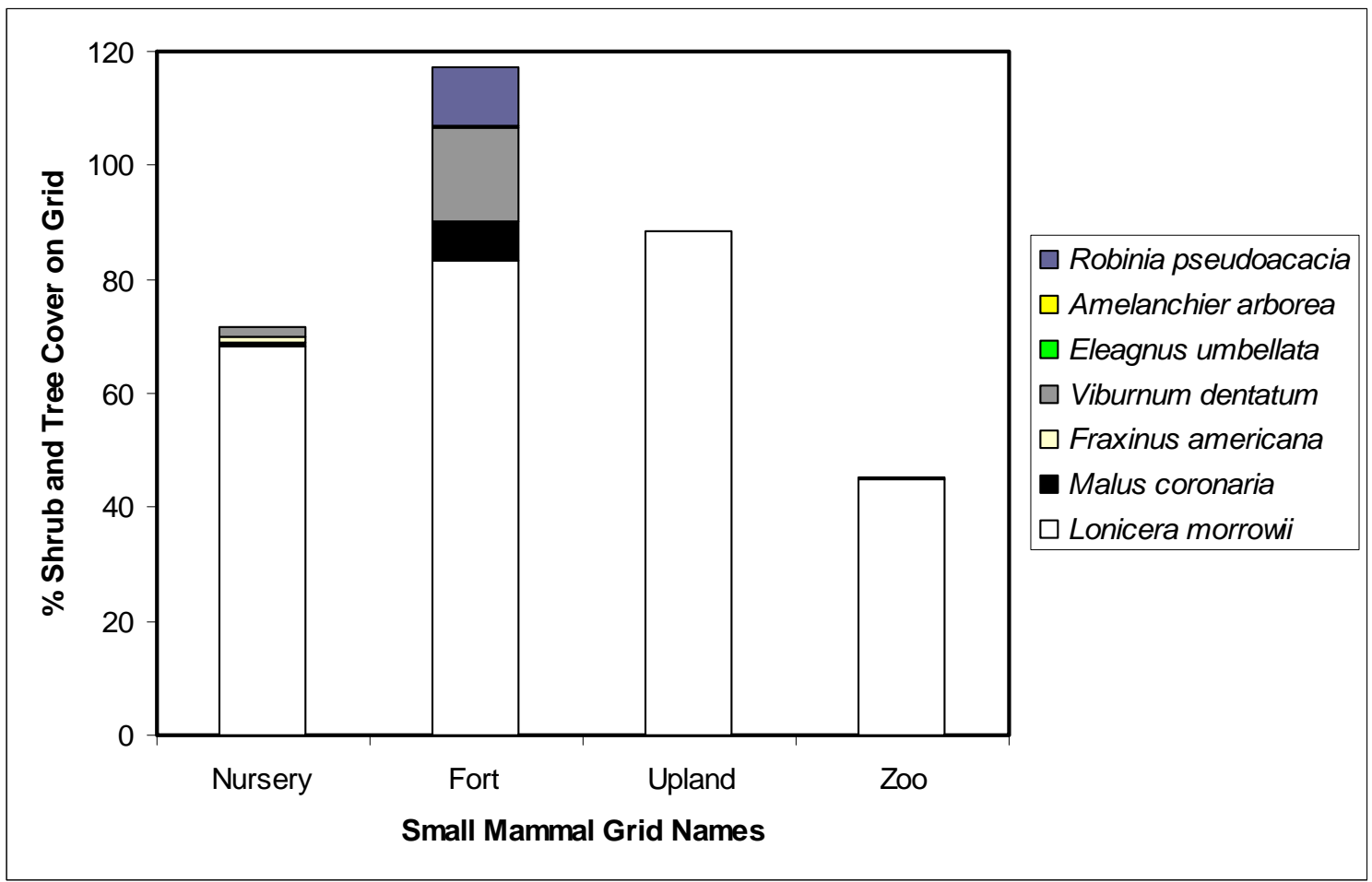

Figure 2. Estimate of $\%$ shrub and tree cover on each of the small mammal grids (Nursery, Fort, Upland, and Zoo) at Fort Necessity National Battlefield in Fayette County, Pennsylvania, USA in 2004 and 2005. Lonicera morrowii was the dominant shrub on all grids. 


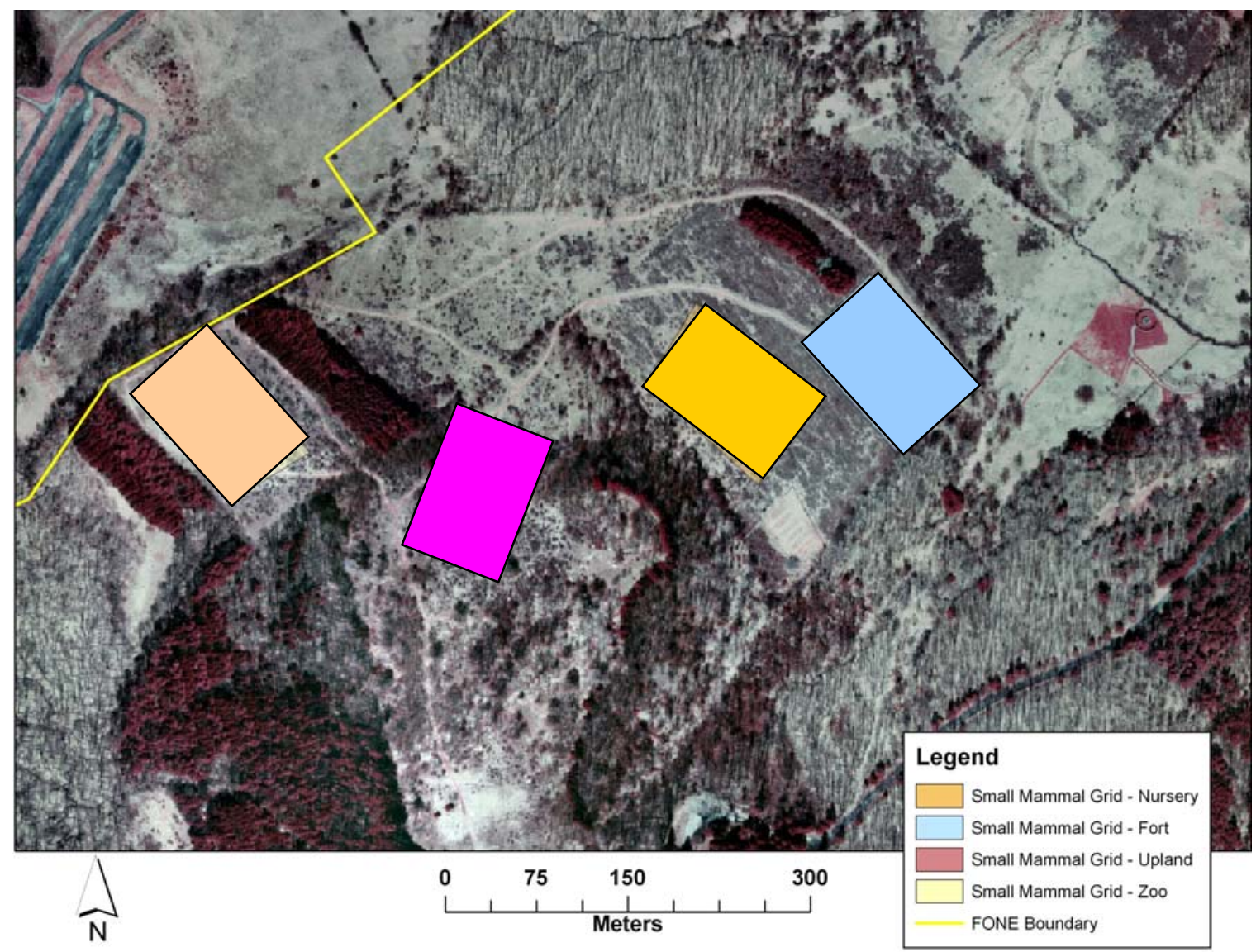

Figure 3. Locations of small mammal grids at Fort Necessity National Battlefield in Fayette County, Pennsylvania, USA during 2004 and 2005. The four grids, each $80 \times$ $120 \mathrm{~m}$, were located in the densest areas of the Morrow's honeysuckle (Lonicera morrowii) invasion. 


\section{CHAPTER III}

Journal of Mammalogy, 00(0):000-000

\section{MICROHABITAT SELECTION OF PEROMYSCUS LEUCOPUS IN MORROW'S HONEYSUCKLE INVADED SITES}

Jennifer A. Edalgo, James T. Anderson, ${ }^{*}$ and Jason P. Love

West Virginia University, P.O. Box 6125

Morgantown, WV 26506-6125, USA

Division of Forestry, West Virginia University, Morgantown, WV, 26505, USA

We used trapping and tracking to examine the microhabitat selected by white-footed mice (Peromyscus leucopus) living among and nearby exotic and invasive Morrow’s honeysuckle (Lonicera morrowii) in Fayette County, Pennsylvania, USA during 2004 and 2005. We compared 4 microhabitat characteristics (\% herbaceous cover, $\%$ shrub cover, $\%$ tree cover, and the protection from predators) among treatments (trap stations $[n$ $=128]$ and animal trails $[n=135])$ and years (2004 and 2005). Among the microhabitat characteristics that we measured, none were used randomly (i.e., herbaceous cover $[P<$ $0.001]$, shrub cover $[P<0.001]$, tree cover $[P<0.001]$, and protection $[P=0.005])$. We also examined the native, exotic, and total herbaceous species community along animal trails $(n=124$ trails) versus the vegetation at random trap stations $(n=127$ traps $)$ by calculating 3 indices: species richness, diversity, and evenness. Native species

*Correspondent: jander25@wvu.edu

This manuscript prepared using the format of the Journal of Mammalogy. 
richness $(P=0.024)$, diversity $(P<0.001)$, and evenness $(P<0.001)$ were used more than expected by $P$. leucopus, whereas, exotic species richness $(P<0.001)$, diversity $(P<$ 0.001), and evenness $(P=0.046)$ were used less than expected. Because mice selected paths with greater shrub and tree cover, and paths with high native/low exotic herbaceous vegetation, areas should be managed to promote these 2 important stratum and exotic herbs should be controlled. Incorporating exotic species control in the shrub and herbaceous stratum may help many small mammal species find adequate microhabitat for survival.

Key words: exotic species, fluorescent pigment, microhabitat selection, Morrow’s honeysuckle, Peromyscus leucopus, powdertracking, small mammal, trapping, vegetation

Numerous small mammal studies measure microhabitat to determine the vegetation that the animals are using (Dueser and Shugart 1978; Price 1978; Dueser and Shugart 1979; Kaufman et al. 1982; Seagle 1985; Menzel et al. 2000; Pearson et al. 2001; Keinath and Hayward 2003; Mengak and Guynn 2003). Microhabitat is composed of physical and chemical variables in the environment that influence the time and energy used by an individual in its home range (Morris 1987). To maintain natural levels of diversity, wildlife managers and policy makers need to understand key habitat requirements for generalist small mammal species that occupy meaningful components of functional ecological communities (Bellows et al. 2005).

Peromyscus spp., the subject of numerous published studies (Jorgensen 2003), is a generalist species and is the most common wild rodent across the United States (Merritt 1987). White-footed mice (Peromyscus leucopus) are typically associated with sparse 
ground cover in studies conducted on relatively undisturbed sites or in pine plantations (Barnum et al. 1992; Pearson et al. 2001; Mengak and Guynn 2003). M'Closkey (1975) found that $P$. leucopus used shrubby habitat with a high branch diversity in proportion to its availability. M'Closkey (1975) also found that P. leucopus was not particularly associated with any one shrub or tree species, indicating that any given plant species occurring at a site may be used as a food source, as structure for exploration or escaping predators, or as a combination of food and structure. McShea and Francq (1984) found that food availability (i.e., acorns and insect larvae) increased P. leucopus use of the ground, shrub, or tree strata where the food supply occurred. We found no studies that quantified the path selection of $P$. leucopus in native or exotic vegetation.

Various investigations have used fluorescent pigments to track the movements of small mammals (Lemen and Freeman 1985; Mullican 1988; Goodyear 1989; McShea and Gilles 1992; Longland and Clements 1995; McCay 2000; Menzel et al. 2000).

Researchers like the powdertracking method because it is non-inhibiting to the animal's movements, fairly inexpensive ( $\$ 12.00$ per pound of powder pigment, Radiant Color, Richmond, California), allows tracking of the animal up to $900 \mathrm{~m}$, low in toxicity, and the powder can mark the animal's vertical movement up trees and stems (Sheppe 1966; Lemen and Freeman 1985). The shortcomings to using the powdertracking method are that it can be time consuming and the powdered animals may produce poor trails in sparsely vegetated areas (Lemen and Freeman 1985).

Our study employed trapping and tracking to examine the microhabitat used by small mammals living among and near Morrow's honeysuckle (Lonicera morrowii), an exotic and invasive shrub from Japan (Rehder 1940). Morrow's honeysuckle reduces 
richness and cover of native herb communities (Batcher and Stiles 2004). Amur honeysuckle (Lonicera maackii) produce a superabundance of low-quality berries that are readily consumed by deer mice (Peromyscus maniculatus) (Williams 1999). The researchers did not know if the seeds were viable after the berries were consumed (Williams 1999). Studies are lacking that examine effects of exotic plants on small mammal communities (Pearson 2001), yet current research suggests that exotic plant invasions, especially Lonicera spp., have a high potential to alter small mammal ecology (Witmer 1996; Williams 1999). As bush honeysuckles continue to spread through the eastern United States (Batcher and Stiles 2004), it is imperative that we examine the microhabitat characteristics that small mammals select in these areas.

We hypothesized that $P$. leucopus would select paths with low density of herbs, native vegetation, and a high protection from predators, but avoid (i.e., use less than available) exotic vegetation. We also hypothesized that $P$. leucopus would not use shrub or tree cover more than the availability. Our objectives were to 1) determine the paths taken by fluorescent powdertracked small mammals within woodland and old field areas with encroaching Morrow's honeysuckle and record the microhabitat characteristics along each powder trail, and 2) determine use and selection of microhabitat characteristics by fluorescent powder-marked $P$. leucopus.

\section{STUdy AREA}

The study was conducted in upland areas at Fort Necessity National Battlefield (FONE) in Fayette County, Pennsylvania, USA. The FONE covers 390 ha in the main park with elevations ranging from 535 - $710 \mathrm{~m}$ (National Park Service 1991; Figure 1). The average annual temperature is $9^{\circ} \mathrm{C}$ and the average annual precipitation is $119 \mathrm{~cm}$; 
annual snowfall surpasses $39 \mathrm{~cm}$ (National Park Service 1991). Soils include moderately deep, moderate to well drained, and medium-textured soils underlain by acidic shale and sandstone bedrock (National Park Service 1991).

According to The Western Pennsylvania Conservancy (unpublished report), the current composition of vegetation has been extensively disturbed and invaded by nonnative species. The study area is predominately herbaceous with highly dense to sparse patches of shrubs (Western Pennsylvania Conservancy, unpublished report). Morrow's honeysuckle has invaded the upland sites; our small mammal grids were located in 2 old field sites and in 2 forested sites (Figure 2). All 4 grids incorporated the Morrow's honeysuckle invasion at FONE with approximately 13\% Morrow's honeysuckle coverage on each grid.

\section{MATERIALS AND METHODS}

We used a grid pattern of 10 transects with 15 traps on each line spaced at $8 \mathrm{~m}$ intervals $(80 \times 120 \mathrm{~m}$ grids). We established 4 grids with 150 trapping stations per grid for a total of 600 trapping stations. We oriented each of the 4 trapping grids to have 2 transects in the Morrow's honeysuckle and the remaining 8 transects were in either woodland or in field habitat. In May, July, and September of 2004 and in May, June, and July of 2005, we baited traps with peanut butter and rolled oats wrapped with wax paper (D. O'Dell, pers. comm.) at $1700 \mathrm{hrs}$ and we checked traps later the same day at $2200 \mathrm{hrs}$ for a total of 13,500 trap nights. We used collapsible Sherman live traps (Small Folding Galvanized, $5 \times 6.4 \times 16.5 \mathrm{~cm}$ ) to capture animals and then used a plastic bag to hold the animal while marked them with a \#1005-1 monel ear tag (National Band and Tag Company, Newport, Kentucky 41072-0430) and recorded the following data and 
measurements: date and time of processing, species, total length, tail length, right ear length, right hindfoot length, mass, age (adult or juvenile), sex, reproductive condition (female: inactive, active, lactating, or pregnant; male: abdominal or testes length), and trap location (McDiarmid and Wilson 1996). Shrews did not have ear pinnae large enough to support the tag, so we toe-clipped shrews (Silvy et al. 2005).

We prepared animals for fluorescent powdertracking using the method described by Leman and Freeman (1985). We placed each animal in a separate quart-sized plastic bag with a small amount of red or green pigment, gently shook it until we saturated the fur of the animal with the fine granules (2-4 $\mu \mathrm{m}$; Radiant Color, Inc.) of the pigment, and then released it from a locked-open trap at the caught location (Lemen and Freeman 1985). The next night, we returned to the site with an ultraviolet 6 Watt Long Wave Lamp/Flashlight to follow the fluorescent trail left by the animal (Lab Safety Supply, Inc.-Lemen and Freeman 1985; Menzel et al. 2000). We placed marker flags along its path every $1 \mathrm{~m}$ and where the trail turned until the trail was no longer visible (Jike et al. 1988; Menzel et al. 2000; McCay 2000).

We took microhabitat measurements the next day along the marked path (Lemen and Freeman 1985, McShea and Gilles 1992, Menzel et al. 2000). Between each $1 \mathrm{~m}$ point along the trail, we subjectively assigned a rectangular area $(1 \mathrm{~m}$ wide $\times 1 \mathrm{~m}$ long $)$ a value of 1 to 3 based on its density of cover for vulnerability to predators (Menzel et al. 2000). We assigned a value of 1 to areas with little protection, a value of 2 to the areas with moderate protection, and a value of 3 to areas that offered a high level of protection (Menzel et al. 2000). We assigned sections of the trail under or beside coarse woody debris (CWD) or in a shrub/tree to cover class of 3. Menzel et al. (2000) used a 
Daubenmire square $(1 \mathrm{~m} \times 1 \mathrm{~m})$ to ground-truth and quantify their estimations of the amount of protection for the mice and we used similar classifications and proportions. We used the Daubenmire square to measure the percentage of vegetation covering the trail for each cover class $(12.5,50.6,89.0 \%$ for class 1, 2, and 3 respectively) (Menzel et al. 2000). We estimated microhabitat use along the fluorescent trails using line-transect sampling (McCay 2000). We stretched a tape along the flagged trail and we recorded the distance of each plant species' coverage (McCay 2000). We divided the distance of tape intersecting vegetation by the total transect length and this provided an estimate of microhabitat used for each powdertracked animal (McCay 2000). We quantified the number of shrub-stems, logs, and rocks that intersected the stretched tape.

We took microhabitat measurements at 128 randomly selected trap locations (32 trap stations per grid) (Barnum et al. 1992). We used Dueser and Shugart's (1978) study design for measuring small mammal microhabitat. At the trap locations, 2 perpendicular arm-length transects $(5 \mathrm{~m})$ provided measures of available species, surface characteristics (i.e., coverage of shrub stems, logs, rocks), density of all intersecting vegetation, and vulnerability to predators (Dueser and Shugart 1978; Menzel et al. 2000). We divided the distance of tape intersecting vegetation by the total transect length and this provided an estimate of microhabitat available at trap locations (McCay 2000).

Statistical analysis - We used multivariate analysis of variance (MANOVA) to compare 4 microhabitat characteristics ( $\%$ herbaceous cover, $\%$ shrub cover, $\%$ tree cover, and the vulnerability to predators; independent variables) between 2 dependent variables, treatment (available microhabitat at trap stations and used microhabitat along animal trails) and between years (2004 and 2005). Following a significant $(P \leq 0.05)$ 
MANOVA (Wilks' $\lambda$ ), we tested the effects of the independent variables on each dependent variable by univariate ANOVAs (Anderson et al. 2000) and Duncan's Multiple Range test (SAS Inst. Inc. 2003). We also used several indices (species richness (S), Shannon-Weiner index of diversity $\left(H^{\prime}\right)$, and Pielou (1966) evenness index $\left(J^{\prime}\right)$ independent variables) to evaluate differences in the herbaceous plant species composition between traps and trails (treatment—-dependent variable; Shannon and Weaver 1949; Magurran 1988). We used univariate ANOVAs and Duncan's Multiple Range test to test the difference in $P$. leucopus use versus availability of native, exotic, and total herbs for each index (PROC GLM; SAS Inst. Inc. 2003).

Data were checked for normality with Shapiro-Wilk Statistic (PROC UNIVARIATE) and homogeneity of variances with Levene's test by plotting residuals (PROC GLM—SAS Inst. Inc. 2003; Cody and Smith 2006). To achieve normality, all independent variables except for $\%$ herbaceous cover were rank-transformed (SAS Inst. Inc. 2003); we added 0.5 to $\%$ herbaceous cover and then square-root transformed that variable. Values presented in this manuscript are untransformed.

Traps having multiple captures were included more than once when the powdermarked trail was followed because the vegetation recorded along the trail was not exactly the same for subsequent captures; however, random traps were measured only once in the analysis. Thus the standard assumption of independence among observations was upheld and pseudoreplication avoided (SAS Inst. Inc. 2003; Pearson et al. 2001).

\section{RESULTS}

In 13,500 trap nights, 201 total captures of 85 individuals were recorded; 135 captures were Peromyscus leucopus. Other species captured and powder-marked 
included: meadow vole (Microtus pennsylvanicus, $n=35$ captures, $n=21$ individuals), meadow jumping mouse (Zapus hudsonius, $n=11$ captures, $n=8$ individuals), woodland jumping mouse (Napaeozapus insignis, $n=7$ captures, $n=6$ individuals), deer mouse (Peromyscus maniculatus, $n=5$ individuals), shorttail shrew (Blarina brevicauda, $n=5$ individuals), masked shrew (Sorex cinereus, $n=4$ individuals), and southern flying squirrel (Glaucomys volans, $n=1$ individual). We examined 135 P. leucopus trails totaling $1,224.15 \mathrm{~m}$ and measured 128 random trap stations totaling $1,280.00 \mathrm{~m}$. The average powder trail length was $9.07 \mathrm{~m}(\mathrm{SE}=0.56 \mathrm{~m})$.

All microhabitat variables differed among treatments (Wilks' $\lambda=0.806, P<$ 0.001 ) and years (Wilks' $\lambda=0.955, P=0.019$ ); however, there was an interaction between treatments and years (Wilks' $\lambda=0.688, P<0.001$ ). Given that variables differed between years and there was a significant interaction, we ran a univariate ANOVA on treatment nested within year to determine the microhabitat variables' effects for each year and then we used Duncan's Multiple Range test to determine the years that differed. Herbaceous cover (\%) differed between treatments in 2004 but not in 2005 (Table 1). In 2004, herbaceous cover was about $38 \%$ greater at trap stations than along trails, but in 2005 , herbaceous cover was only about $1 \%$ greater along trails than at trap stations. Shrub cover (\%) and tree cover (\%) were both used greater at trails than at trap sites. Protection values differed overall between treatments within each year. In 2004, protection values were the same at trap stations and along trails, but in 2005, protection values were about $21 \%$ greater for trails than trap stations.

A list of all plant species recorded at traps and trails and their exotic or native status are displayed in Appendix III; the 10 most common native herb species and exotic 
herb species are displayed in Table 2. Unknown herbaceous vegetation ( $n=19$ herbs) was not included in analyses, nor were traps $(n=1)$ or trails $(n=11)$ with no herbaceous vegetation. Total species richness for herbs did not vary $(F=0.01$, d.f. $=1,250, P=$ $0.971)$ among treatments, however, differences among traps $(n=127)$ and trails $(n=124)$ existed for native species richness $(F=5.16$, d.f. $=1,250, P=0.024)$ and exotic species richness $(F=17.57$, d.f. $=1,250, P<0.001-$ Table 3$)$. The native species richness was about $16 \%$ greater on trails, and the exotic species richness was about $42 \%$ greater on trap stations.

Herbaceous diversity indices for native $(F=21.23$, d.f. $=1,250, P<0.001)$, exotic $(F=13.76$, d.f. $=1,250, P<0.001)$, and total species $(F=8.29$, d.f. $=1,250, P=$ 0.004 ) varied between traps and trails (Table 3 ). Total herb diversity was about $20 \%$ greater on trails than at trap stations. Native herb diversity was about $63 \%$ greater on trails than at trap stations, whereas exotic herb diversity was about $38 \%$ greater at trap stations than along trails.

Herbaceous species evenness indices for native $(F=21.99$, d.f. $=1,250, P<$ $0.001)$, exotic $(F=4.02$, d.f. $=1,250, P=0.046)$, and total species $(F=14.10$, d.f. $=1$, $250, P<0.001$ ) varied between traps and trails (Table 3). Trails had about $41 \%$ greater total species evenness than trap stations. Trails had $67 \%$ greater native herb evenness, whereas traps have greater exotic herb evenness (about 26\%).

\section{Discussion}

Many differences existed between the actual microhabitat characteristics used and the available vegetation measured at trap stations (i.e., herbaceous cover, shrub cover, tree cover, native and exotic herb cover, the amount of protection). Based on these 
results for the microhabitat characteristics measured, $P$. leucopus actively selected its paths within woodland and old field areas with encroaching Morrow's honeysuckle.

Our results for 2004 agree with Barnum et al. (1992), Pearson et al. (2001), and Mengak and Guynn (2003), that Peromyscus chose areas with a lower percent cover of herbaceous vegetation and avoided areas of heavy vegetative cover. One explanation given by Pearson et al. (2001) for the mice favoring more thinly vegetated areas, is that they may be responding to their predators that easily hunt in dense vegetation (i.e., raccoon [Procyon lotor], black rat snake [Elaphe obsoleta], feral cat [Felis catus], weasel [Mustela frenata], and coyote [Canis latrans]) rather than raptors that prefer to hunt in more open areas. The mice are able to move quicker and more quietly through the sparsely vegetated areas and could escape predation more easily (Barnum et al. 1992). Conversely, Peromyscus may be better able to forage on grass and forb seeds, as well as insects in less dense vegetation (Pearson et al. 2001). In 2005, P. leucopus did not use areas greater or less than expected based on the $\%$ coverage of herbaceous vegetation.

The results of shrub habitat selection agree with other studies (Dueser and Shugart 1978; Kaufman et al. 1982) that found P. leucopus used shrub habitat more than it was available. In this study, P. leucopus used shrubs more than their availability. Morrow's honeysuckle is used as both a food source and as structural cover for $P$. leucopus (M'Closkey 1975; Williams 1999) and the honeysuckle berries may have increased the use of the shrub strata (McShea and Francq 1984). This exotic shrub produces a plethora of soft mast in the summer and has invaded FONE up to a density of 72,000 $\pm 4,800$ plants/ha which totaled $248,587 \pm 13,825$ stems/ha (Love et al. 2005). The importance of the berries for wildlife may be overstated, given that the fruit is high in sugars, but 
relatively low in lipids and protein (Witmer 1996, Williams 1999). The branch structure of Morrow's honeysuckle is similar, but more dense than that of staghorn sumac (Rhus typhina) which M'Closkey (1975) reported a slightly higher use of by P. leucopus. Shrub cover at FONE was found to be important to P. leucopus, a microhabitat generalist (Dueser and Shugart 1978); however, it is not our recommendation to promote any exotic, invasive shrub species when native shrubs (i.e., Southern arrowwood [Viburnum dentatum], common serviceberry [Amelanchier arborea], waxyfruit hawthorne [Crataegus pruinosa], and deerberry [Vaccinium stamineum]) may sufficiently serve the same function.

Tree cover was also selected over areas without tree cover. These results agree with Dueser and Shugart (1978) and Kaufman et al. (1982) who also found that Peromyscus selected sites with primarily woody species and cover over sites without tree cover. Other studies have found the habitat of $P$. leucopus to include a thin overstory of young pines (Mengak and Guynn 2003) or to be depicted by a well-developed canopy of deciduous woody species, large stumps, and a complex vertical structure (Dueser and Shugart 1978); either description includes a positive association with tree cover.

Protection values took into consideration the combination of herb, shrub, and tree cover, as well as rocks or logs that small mammals could travel underneath. In 2005, animal trails presented the highest amount of protection indicating P. leucopus selected areas with greater protection, however, in 2004, no selectivity occurred. P. leucopus has numerous predators (i.e., nocturnal, crepuscular, and diurnal) to protect itself from and at the very least, the nocturnal (i.e., barred owl [Strix varia], eastern screech owl [Otus asio], and barn owl [Tyto alba]) and crepuscular (i.e., red fox [Vulpes vulpes] and bobcat 
[Lynx rufus]) predators presented a potential threat as we released the small mammals at night (Menzel et al. 2000). In 2004, small mammals may have been reducing their vulnerability to predators in ways that were not detected by our quantification with the Daubenmire square.

Use and selectivity of exotic or native vegetation by small mammals, particularly Peromyscus, a generalist species, has not been described. Mazzotti et al. (1981) cautions that although they caught low numbers of rodents in a monoculture of exotic trees, exotic plant communities cannot unthinkingly be classified as biological deserts. Moreover, most studies have relatively similar capture rates (Table 4). The present study shows that only examining the total plant species richness, diversity, and evenness does not reveal the actual selection of vegetation by P. leucopus. If we only explored the total species indices without splitting the herbs into exotic and native species, we would conclude the following: P. leucopus randomly used areas based on the species richness; however, they selected areas of greater species diversity and greater evenness. These conclusions may be misleading, given that our separation of native species and exotic species revealed a clearer understanding of plant community selection by $P$. leucopus. Native species richness, diversity, and evenness were selected, whereas, exotic species richness, diversity, and evenness were avoided. Even though the mice used areas of less dense herbaceous vegetation, they selected native herbs to travel through and avoided exotic herbs in their path.

We believe that their selectivity concerned food sources that the native vegetation provided and that the exotic vegetation did not provide (i.e. seed, fruit, or insects). Ortega et al. (2004) noted that Peromyscus populations are food limited, using exotic 
plants or any plant as long as they supply accessible food. A study currently underway has found fewer insects on and under Morrow's honeysuckle rather than on a native shrub, southern arrowwood (Love et al. 2005). As exotic plants continue to invade and transform native habitats, changes in small mammal species composition will undoubtedly alter food-web interactions as well as the specific roles in ecosystem functions such as herbivory, seed and insect predation, seed dispersal, etc. (Pearson et al. 2001). Due to these results showing that $P$. leucopus selected native vegetation and avoided exotic vegetation, we suggest promoting native vegetation and controlling the invasion of nonnative plants. Shrub and tree cover also were exceptionally important to $P$. leucopus, because areas with greater shrub coverage and tree coverage were selected in both 2004 and 2005. We also recommend promoting native shrubs and trees together because Peromyscus spp. tend to be food-limited (Ortega et al. 2004) and native shrubs and trees typically provide higher-quality fruits than exotics, notably Lonicera spp. (Williams 1999).

\section{ACKNOWLEDGMENTS}

This work was funded by the National Park Service and Fort Necessity National Battlefield in Farmington, Pennsylvania. We thank Connie A. Ranson and John W. Edwards for reviewing this manuscript. We thank Mark Hepner, Jason Alexander, Jennifer Love, and Robbie Edalgo from West Virginia University who assisted with field work. We thank George Seidel for statistical guidance. This is scientific article number XXXX of the WVU Agricultural and Forestry Experimental Station. The West Virginia University Animal Care and Use Committee approved our animal handling protocols (040104). 


\section{LITERATURE CiTED}

ANDERson, J. T., L. M. Smith, AND D. A. HAuKos. 2000. Food selection and feather molt by nonbreeding American green-winged teal in Texas playas. Journal of Wildlife Management 64:222-230.

Barnum, S. A., C. J. Manville, J. R. Tester, And W. J. Carmen. 1992. Path selection by Peromyscus leucopus in the presence and absence of vegetative cover. Journal of Mammalogy 73:797-801.

BATCHER, M. S. AND StiLes, S. A. Element Stewardship Abstract for the Bush Honeysuckles, The Nature Conservancy. http://tncweeds.ucdavis.edu/esadocs/documnts/loni sp.html. Accessed February $10,2004$.

BEER, J. R. 1964. Bait Preferences of some small mammals. Journal of Mammalogy 45:632-634.

Burnham, K. P. AND D. R. ANDERSON. 2004. Multimodel inference: understanding AIC and BIC in model selection. Sociological Methods and Research 33:261304.

Chitty, D. And D. A. KemPSOn. 1949. Prebaiting small mammals and a new trap design of live trap. Ecology 30:536-542.

CODY, R. P. AND J. K. SMITH. 2006. Applied statistics and the SAS programming language. Fifth edition. Elsevier Science Publishing Co., Inc., New York, New York, USA.

DUESER R. D. AND H. H. SHUgarT, JR. 1978. Microhabitats in a forest-floor small mammal fauna. Ecology 59:89-98. 
DUESER R. D. AND H. H. ShUGART, JR. 1979. Niche pattern in a forest-floor smallmammal fauna. Ecology 60:108-118.

GOODYEAR, N. C. 1989. Studying fine-scale habitat use in small mammals. Journal of Wildlife Management 53:941-946.

JiKe, L., G. O. BATZLI, L. L. GetZ. 1988. Home ranges of prairie voles as determined by radiotracking and by powdertracking. Journal of Mammalogy 69:183-186.

JoRGENSEN, E. E. 2003. Small mammal use of microhabitat reviewed. Journal of Mammalogy 85: 531-539.

Kaufman, D. W., S. K. Peterson, R. Fristik, AND G. A. Kaufman. 1982. Effect of microhabitat features on habitat use by Peromyscus leucopus. The American Midland Naturalist 110:177-185.

KeINATH, D. A. AND G. D. HAYWARD. 2003. Red-backed vole (Clethrionomys gapperi) response to disturbance in subalpine forests: use of regenerating patches. Journal of Mammalogy 84:956-966.

LEMEN, C. A. AND P. W. FreEMAN. 1985. Tracking mammals with fluorescent pigments: a new technique. Journal of Mammalogy 66:134-136.

LONGLAND, W. S. AND C. CLEMENTS. 1995. Use of fluorescent pigments in studies of seed caching by rodents. Journal of Mammalogy 76:1260-1266.

Love, J. P., J. A. EdAlgo, AND J. T. ANDERson. 2005. Management plan for a degraded meadow with Morrow's honeysuckle. Fort Necessity National Battlefield, Fayette County, Pennsylvania. Unpublished report.

MagurRan, A. E. 1988. Ecological diversity and its measurement. Princeton University Press, Princeton, NJ, USA. 
Mazzotti, F. J., W. OstrenKo, AND A. T. SMith. 1981. Effects of the exotic plants Melaleuca quinquenervia and Casuarina equisetifolia on small mammal populations in the eastern Florida Everglades. Florida Scientist 44:65-71.

MCCAY, T. S. 2000. Use of woody debris by cotton mice (Peromyscus gossypinus) in a southeastern pine forest. Journal of Mammalogy 81:527-535.

MCDiARmid, R. W. AND D. E. WiLSON. 1996. Data standards. Pages 56-60 in Wilson, D. E., F. R. Cole, J. D. Nichols, R. Rudran, and M. S. Foster. 1996. Measuring and monitoring biological diversity. Smithsonian Institution Press. Washington, D.C.

McGarigal, K., S. Cushman, S. StafFord. 2000. Multivariate statistics for wildlife and ecology research. Springer-Verlag New York, Inc., New York, New York, USA. 283pp.

M'Closkey, R. T. 1975. Habitat dimensions of white-footed mice, Peromyscus leucopus. American Midland Naturalist 93:158-167.

MCShEA, W. J. AND A. B. GiLLES. 1992. A comparison of traps and fluorescent powder to describe foraging for mast by Peromyscus leucopus. Journal of Mammalogy $73: 218-222$.

McShea, W. J. and E. N. FrancQ. 1984. Microhabitat selection by Peromyscus leucopus. Journal of Mammalogy 65:675-678.

MENGAK, M. T. AND D. C. GUYNN JR. 2003. Small mammal microhabitat on young loblolly pine regeneration areas. Forest Ecology and Management 173:309-317. 
Menzel, M. A., T. C. CARTer, L. R. Jablonowski, And J. LAerm. 2000. The effect of time of release on microhabitat use by the white-footed mouse. Acta Theriologica 45:167-173.

MerRitT, J. F. 1987. Mammals of Pennsylvania. University of Pittsburgh Press, Pittsburgh, Pennsylvania, USA.

MORRIS, D. W. 1987. Ecological scale and habitat use. Ecology 68:362-369.

Mueller-Dombois, D. AND H. EllenBerg. 1974. Aim and methods of vegetation ecology. John Wiley \& Sons, Inc., New York.

MulliCAN, T. R. 1988. Radio telemetry and fluorescent pigments: a comparison of techniques. Journal of Wildlife Management 52:627-631.

National Park Service. 1991. General Management Plan/Development Concept Plan/Interpretive Prospectus: Fort Necessity National Battlefield. Prepared by the Denver Service Center. 92pp.

Ortega, Y. K., D. E. Pearson, And K. S. McKelvey. 2004. Effects of biological control agents and exotic plant invasions on deer mouse populations. Ecological Applications 14:241-253.

Pearson, D. E., Y. K. Ortega, K. S. McKelvey, and L. F. Ruggiero. 2001. Small mammal communities and habitat selection in northern Rocky Mountain Bunchgrass: implications for exotic plant invasions. Northwest Science 75:107117.

PIELOU, E. C. 1966. The measurement of diversity in different types of biological collections. Journal of Theoretical Biology 13:131-144. 
PRICE, M. V. 1978. The role of microhabitat in structuring desert rodent communities. Ecology 59:910-921.

REHDER, A. 1940. A manual of cultivated trees and shrubs. Second edition. MacMillan Publishing Company, New York, USA.

SAS InSt. INC. 2003. Statistical analysis system: user's guide, version 9.1. SAS Institute Inc., Cary, North Carolina, USA.

SHEPPE, W. 1967. The effects of livetrapping on the movements of Peromyscus. The American Midland Naturalist 78:471-480.

SILVY, N. J., R. R. LOPEZ, AND M. J. PETERSON. 2005. Wildlife marking techniques. Sixth edition. Pages 339-376 in C. E. Braun, editor. Techniques for wildlife investigations and management. The Wildlife Society, Bethesda, Maryland, USA.

SEAGLE, S. W. 1985. Patterns of small mammal microhabitat utilization in cedar glade and deciduous forest habitats. Journal of Mammalogy 66:22-35.

SHANnON, C. E. AND W. WeAVER. 1949. The mathematical theory of communication. Univerissty of Illinois Press, Urbana, IL, USA.

Thompson, S. D. 1982. Microhabitat utilization and foraging behavior of bipedal and quadrupedal heteromyid rodents. Ecology 63:1303-1312.

Western Pennsylvania Conservancy. 2003. Plant community mapping and surveys for species of special concern at Allegheny Portage Railroad National Historic Site, Johnstown Flood National Memorial, Fort Necessity National Battlefield, and Friendship Hill National Historic Site. 82pp. 
WiLliams, C. E. 1999. Fruits of alien shrubs and deer mice: a test of the persistent fruit defense hypothesis. Journal of the Pennsylvania Academy of Science 73:33-37.

WITMER, M. C. 1996. Consequences of an alien shrub on the plumage coloration and ecology of Cedar Waxwings. Auk 113:735-743. 
Table 1. Results from analysis of variance (ANOVA) and sample estimates of the treatment means and SE for each of the 4 habitat variables (\% cover) measured at Fort Necessity National Battlefield in Fayette County, Pennsylvania, USA in 2004 and 2005.

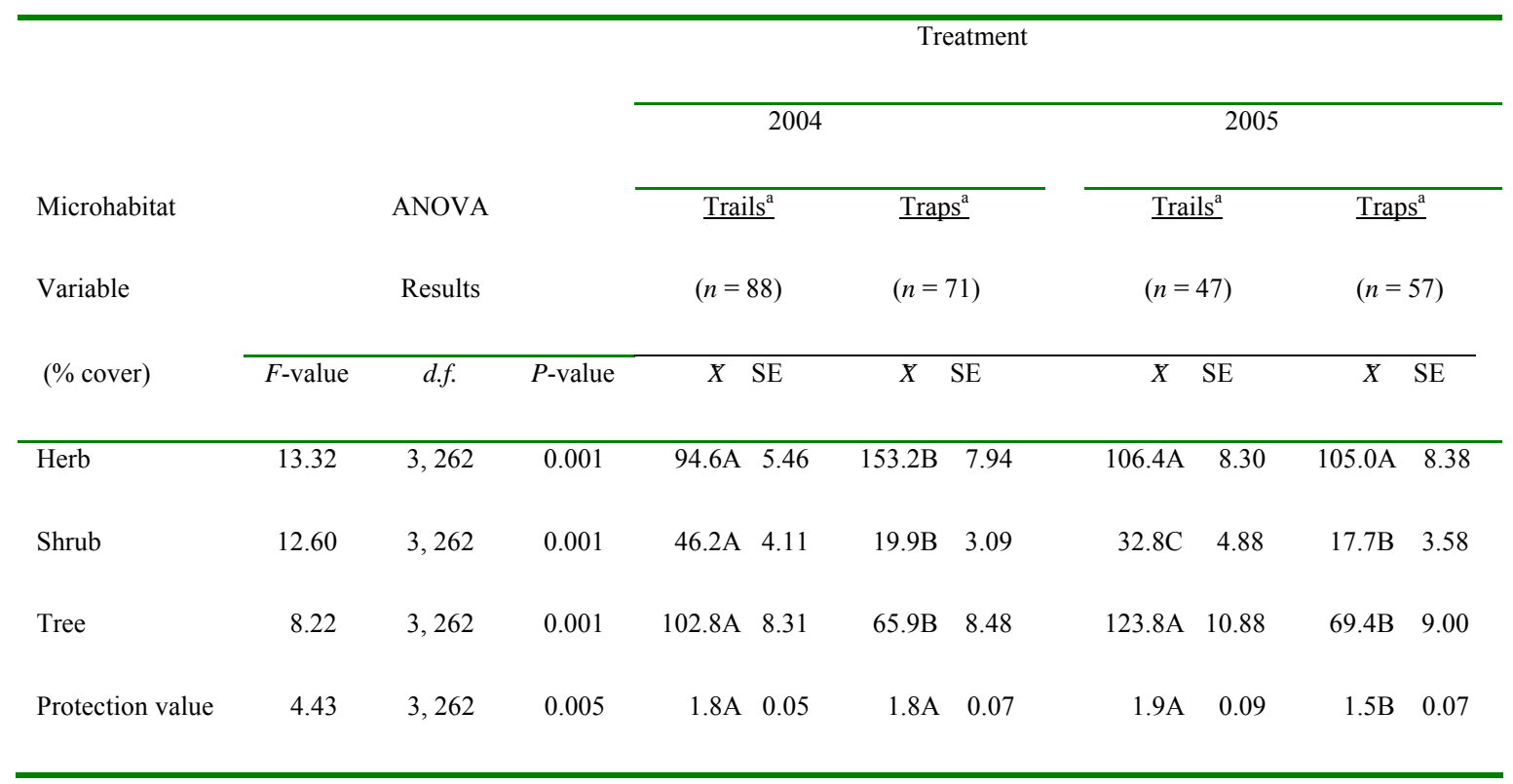

${ }^{a}$ Different letters within rows indicate means differ $(P<0.05)$ between treatments according to ANOVA and Duncan's Multiple Range tests 
Table 2. Dominant native and exotic herbaceous species at trap stations $(n=128 ; 1,280.0 \mathrm{~m}$ total distance) and along animal trails $(n$

$=135 ; 1,224.15 \mathrm{~m}$ total distance) at Fort Necessity National Battlefield in Fayette County, Pennsylvania, USA in 2004 and 2005.

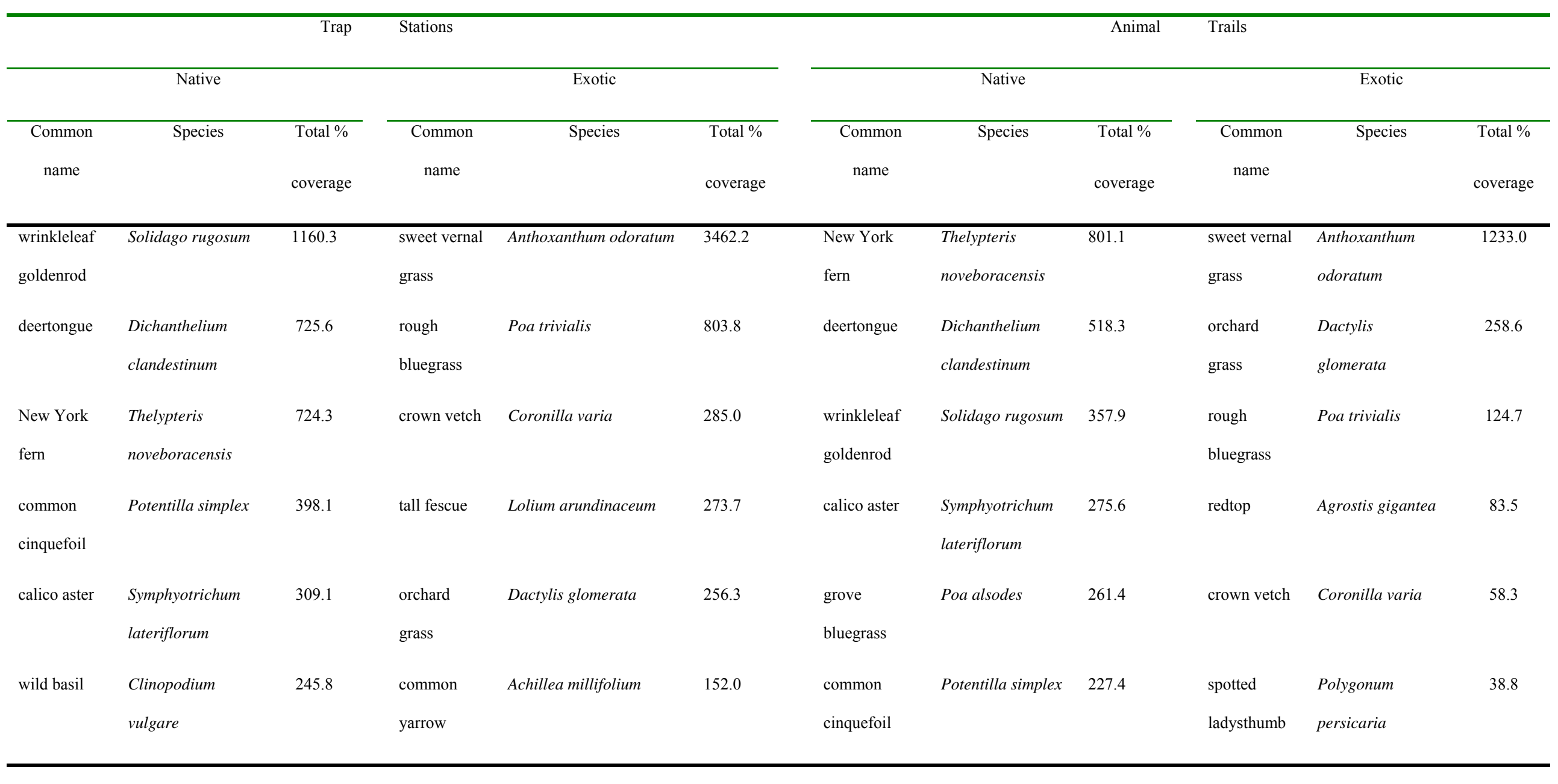


Table 2. Continued.

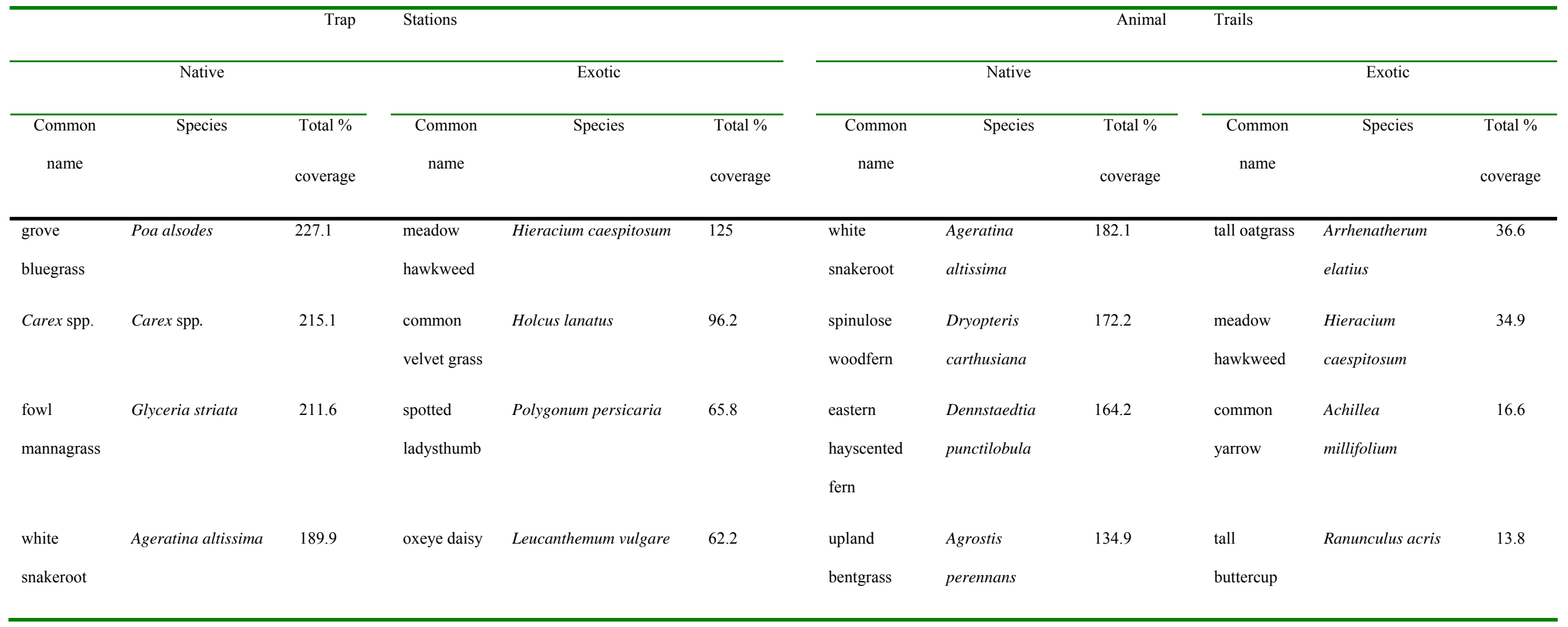


Table 3. Results from analysis of variance (ANOVA) on herbaceous indices (richness, diversity, and evenness) and sample estimates of the treatment means and SE for each of the 3 habitat variables ( $\%$ cover $)$ measured at Fort Necessity National Battlefield in Fayette County, Pennsylvania, USA in 2004 and 2005.

\begin{tabular}{|c|c|c|c|c|c|c|c|}
\hline \multirow{4}{*}{$\begin{array}{l}\text { Herbaceous } \\
\text { Variable } \\
\text { (\% cover) }\end{array}$} & & & \multicolumn{5}{|c|}{ Treatment } \\
\hline & \multicolumn{3}{|c|}{ ANOVA } & \multicolumn{2}{|c|}{ Trails $^{\mathrm{a}}$} & \multicolumn{2}{|c|}{ Traps $^{\mathrm{a}}$} \\
\hline & \multicolumn{3}{|c|}{ Results } & \multicolumn{2}{|c|}{$(n=125)$} & \multicolumn{2}{|c|}{$(n=127)$} \\
\hline & $F$-value & d.f. & $P$-value & $\overline{\bar{X}}$ & SE & $\overline{\bar{X}}$ & SE \\
\hline \multicolumn{8}{|l|}{ Total Herb } \\
\hline Richness & 0.01 & 1,250 & 0.971 & $15.78 \mathrm{~A}$ & 0.99 & $15.83 \mathrm{~A}$ & 0.66 \\
\hline Diversity & 8.29 & 1,250 & 0.004 & $4.05 \mathrm{~A}$ & 0.28 & $3.24 \mathrm{~B}$ & 0.07 \\
\hline Evenness & 14.10 & 1,250 & 0.001 & $2.14 \mathrm{~A}$ & 0.24 & $1.26 \mathrm{~B}$ & 0.03 \\
\hline
\end{tabular}

Native

$\begin{array}{lrrrrrrr}\text { Richness } & 5.16 & 1,250 & 0.024 & 13.05 \mathrm{~A} & 0.80 & 11.01 \mathrm{~B} & 0.42 \\ \text { Diversity } & 21.23 & 1,250 & 0.001 & 1.09 \mathrm{~A} & 0.15 & 0.40 \mathrm{~B} & 0.02 \\ & & & & & & & \\ \text { Evenness } & 21.99 & 1,250 & 0.001 & 0.56 \mathrm{~A} & 0.08 & 0.18 \mathrm{~B} & 0.02\end{array}$

Exotic

$\begin{array}{lccccccc}\text { Richness } & 17.57 & 1,250 & 0.001 & 2.70 \mathrm{~A} & 0.31 & 4.68 \mathrm{~B} & 0.36 \\ \text { Diversity } & 13.76 & 1,250 & 0.001 & 0.98 \mathrm{~A} & 0.14 & 1.60 \mathrm{~B} & 0.09 \\ \text { Evenness } & 4.02 & 1,250 & 0.046 & 0.75 \mathrm{~A} & 0.11 & 1.01 \mathrm{~B} & 0.07\end{array}$

${ }^{a}$ Different letters within rows indicate the index means differ $(P<0.05)$ between treatments according to ANOVA and Duncan's Multiple Range tests. 
Table 4. Comparison of the number of trap nights and white-footed mice (Peromyscus leucopus) capture rates from this study at Fort Necessity National Battlefield in Fayette County, Pennsylvania, USA from 2004-2005 to other small mammal studies throughout the United States.

\begin{tabular}{lcrr}
\hline \multicolumn{1}{c}{ Study } & Location & No. Trap Nights (TN) & Capture Rate (captures/TN) \\
\hline Edalgo et al. (current) & PA & 13,500 & 0.01 \\
Mengak and Guynn 2003 & SC & 33,201 & $<0.01$ \\
Menzel et al. 2000 & GA & 875 & 0.04 \\
Barnum et al. 1992 & MN \& MD & 990 & 0.03 \\
McShea and Gilles 1992 & VA & 5,200 & 0.09 \\
Seagle 1985 & TN & 7,680 & $<0.01$ \\
McShea and Francq 1984 & NH & 10,736 & 0.06 \\
Kaufman et al. 1982 & KS & 1,686 & 0.11 \\
Mazzotti et al. 1981 & FL & 5,160 & 0.03 \\
Dueser and Shugart 1979 & TN & 9,696 & 0.02 \\
Dueser and Shugart 1978 & TN & 9,696 & 0.02 \\
\hline
\end{tabular}




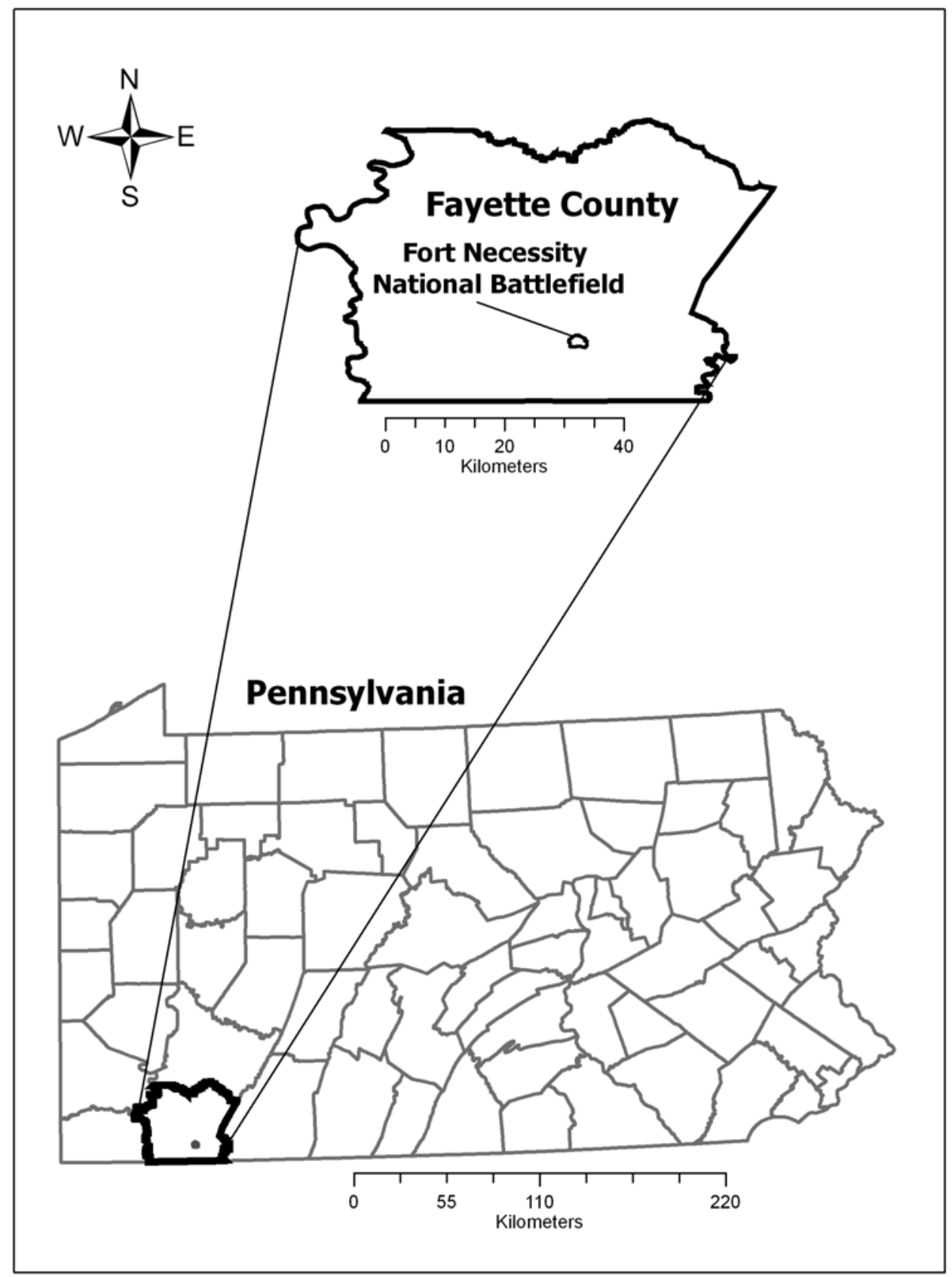

Figure 1. The Fort Necessity National Battlefield in Fayette County, Pennsylvania, USA. 


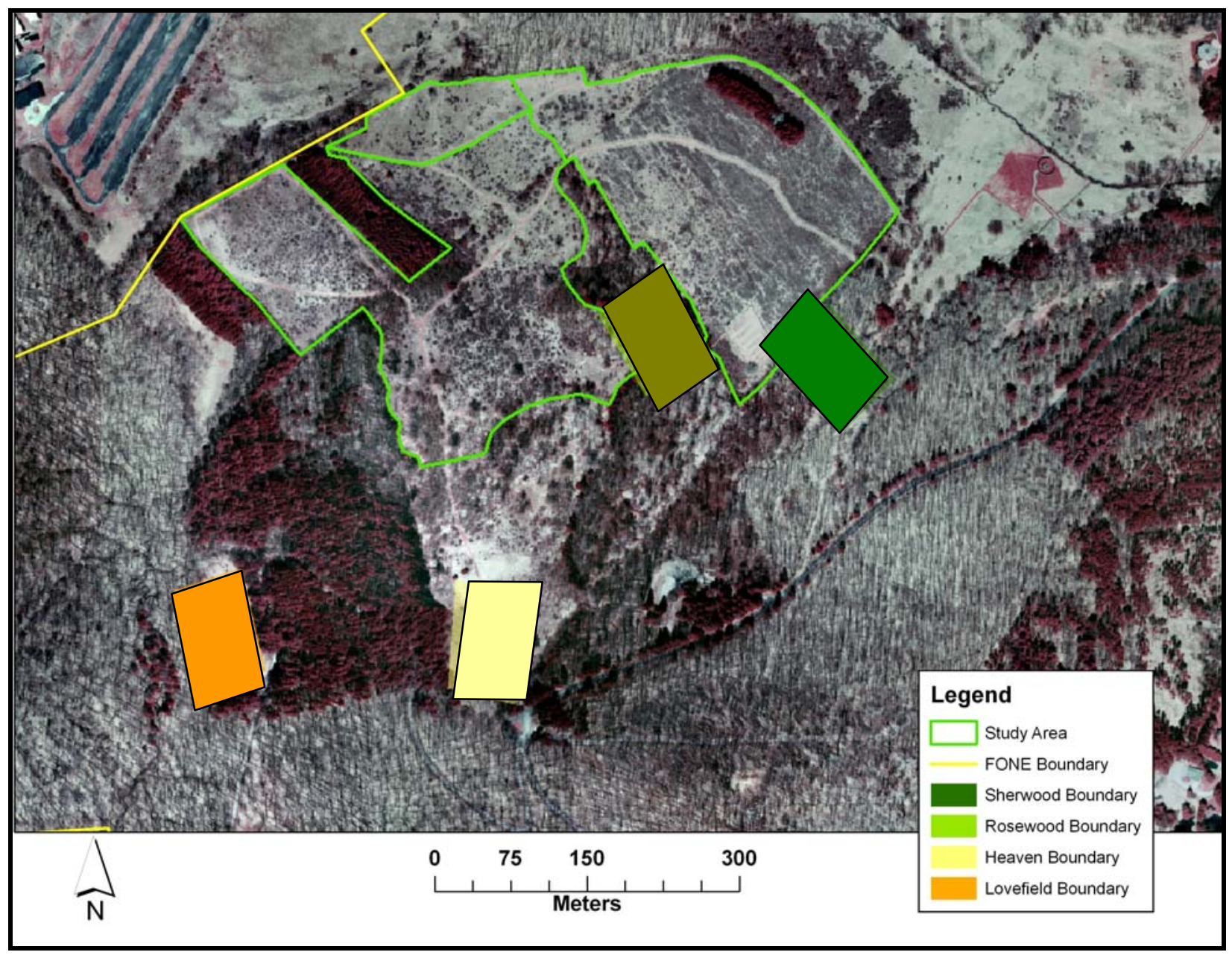

Figure 2. Locations of small mammal grids at Fort Necessity National Battlefield in Fayette County, Pennsylvania, USA during 2004 and 2005. The 4 grids were located outside the study area where separate studies took place; 2 of the grids (Sherwood and Rosewood) were located in the forest, while the remaining 2 grids (Heaven and Lovefield) were located in old fields. 


\title{
CHAPTER IV
}

Biological Invasions 00: 000-000, 2005.

\section{PREDICTING FACTORS THAT DRIVE EARTHWORM COMMUNITIES AND IMPLICATIONS FOR RESTORING A DEGRADED ECOSYSTEM}

\author{
J.A. Edalgo \& J.T. Anderson* \\ West Virginia University, 321 Percival Hall, Morgantown, WV 26505, USA; \\ *Author for correspondence (e-mail: jander25@wvu.edu; fax: 304-293-2441)
}

Key words: Eisenia rosea, exotic earthworms, invasion, Lonicera morrowii, Lumbricus rubellus, Octolasion tyrtaeum, restoration, soil

\begin{abstract}
We developed 6 equations to predict earthworm abundance at Fort Necessity National Battlefield (FONE), Pennsylvania, USA from 2004-2005. We compared the performance of the competing models using Akaike's Information Criterion with small sample size adjustment $\left(\mathrm{AIC}_{\mathrm{c}}\right)$. The factors that predicted the presence of the earthworms differed for each of the 4 worm species found at FONE. For Eisenia rosea, the shrub species model best predicted densities of this worm (e.g., tulip poplar (Liriodendron tulipifera) had the highest average density of worms), but the equation using the carbon: nitrogen ratio ( $\mathrm{y}=$ $1.8274-(2.3722 \times(\mathrm{C} / \mathrm{N}))$ also had substantial support as a useful model. Lumbricus rubellus presence was best predicted by the shrub/tree species model; tulip poplar had the highest average density. For Lumbricus terrestris, 3 models performed well at predicting
\end{abstract}

This chapter is written in the style of the Biological Invasions. 
its density; as a result we used model averaging to incorporate the abiotic factors into a single model $Y=2.9044-(0.0596 \times \mathrm{SM})-(1.1602 \times \mathrm{pH})-(1.7141 \times \mathrm{C} / \mathrm{N})$ and we report that the maximum abundances of Lumbricus terrestris were found underneath tulip poplar and Morrow's honeysuckle (Lonicera morrowii). Octolasion tyrtaeum presence was best predicted by the equation using the carbon: nitrogen ratio $(y=0.0631+(2.8298$ $\times(\mathrm{C} / \mathrm{N})))$. Given the well-documented descriptions of these 4 earthworm species' ecological strategies, we recommend that these models be considered in other similar areas. Moreover, southern arrowwood (Viburnum dentatum), a native shrub, is associated with lower abundances of 3 of the 4 exotic earthworms and should be considered in revegetation plans for the site.

\section{Introduction}

Earthworms are widely believed to reflect soil health (Aplet 1990) and are considered keystone organisms in regulating nutrient cycling processes in ecosystems (Parmelee et al. 1998). Paoletti and Bressan (1996) state that earthworms can serve as monitors of anthropogenic degradation to the soil quality. For ecosystem conservation and restoration, Scheu and Schulz (1996) emphasize that documentation of the composition and abundance of soil fauna must occur in the midst of mild human disturbance and during recovery from severe disturbance. Severely disturbed land is likely to have a high percentage of exotic earthworm species present (Kalisz and Dotson 1989, Kalisz and Wood 1995). We report here a study to predict the earthworm community in a severely disturbed area due to the land use history including: straightening the streams and draining the wetland to create a dry meadow, adding fill (soil) to the meadow, plowing 
the area and using it for pasture land, and the increasing invasion of exotic plant species (National Park Service 1991).

Earthworms may prefer to live in the soil underneath certain plants and they may be linked with particular soil characteristics. Edwards and Bohlen (1996) noted that a high amount of variation was found in earthworm populations in time and space with regard to climate, soil properties, vegetation and food resources, and biotic interactions with other soil fauna. These populations may range from less than 10 to over 1,000 individuals per square meter (Edwards and Bohlen 1996). Earthworms also may choose to live in certain areas over others based on the organic matter in the litter layer. The palatability of the plant material (whether it has high amounts of phenolic compounds, nitrogen, carbon, phosphorus, etc.) may play a large factor in where earthworms colonize (Bohlen et al. 2004a).

One of the most pervasive and threatening plants to the landscape in the eastern United States is the bush honeysuckle (Lonicera spp.), particularly Morrow's honeysuckle (L. morrowii) in wetter areas (Nyboer 1992). Lonicera morrowii, native to Japan, is now common in most northeastern and mid-Atlantic states, as well as southeastern and south-central Canada (Rehder 1940, Nyboer 1992). The shrubs have been promoted for decades for their wildlife, shelterbelt, and ornamental value, but studies show they can have many negative impacts including: impeding forest regeneration, reducing the richness and cover of herb communities, and providing less nutritious fruits than native fruit-bearing shrubs (i.e., Viburnum spp.) (Williams 1999, Batcher and Stiles 2004). 
Understanding earthworm communities in areas with spreading exotic plant species is not well addressed. We found no research that documented earthworm communities under any Lonicera spp. Kourtev et al. (1999) believe that exotic plants and exotic worms reinforce each other's population growth and perpetuate soil conditions that favor one another. If this is the case, then sites invaded by exotic worms may be even more difficult to restore to native vegetation (Kourtev et al. 1999). Knowledge of earthworm abundance and species composition under L. morrowii versus under other native shrubs and trees will allow management decisions to be based on the best data for reintroducing and promoting native vegetation and provide ecologists with a greater understanding of earthworm distribution in areas dominated by exotic vegetation.

The primary goal of this study was to determine the relation of earthworm communities to edaphic and biotic characteristics. Specific objectives were to:

1) Determine and compare earthworm abundance found underneath native and exotic shrub/tree species and in open spaces;

2) Relate the soil microhabitat underneath the shrub/tree species and open spaces to the earthworm abundance under the same shrub/tree species; and

3) Determine the importance of each existing shrub/tree species, or lack of shrubs/trees (open spaces) for the continuation of a healthy earthworm population, and to provide management recommendations prior to implementing restorative action.

\section{Materials and methods}

\section{Study site}

The study was conducted on the 390 ha Fort Necessity National Battlefield in Fayette County, Pennsylvania, USA (Figure 1 and Appendix IVa). Elevations range from 535 - 
$710 \mathrm{~m}$ (National Park Service 1991). The average annual temperature is $9^{\circ} \mathrm{C}$ and the average annual precipitation is $119 \mathrm{~cm}$; annual snowfall surpasses $39 \mathrm{~cm}$ (National Park Service 1991). Earthworms were sampled in Philo silt loam (Ph) (Appendix IVb), which occupied the riparian and wet meadow area (Kopas 1973, National Park Service 1991). Upland areas sampled were characterized by Brinkerton and Armagh silt loams $(\mathrm{BaB})$ with $3-8 \%$ slopes, Cavode silt loams $(\mathrm{CaC} 2)$ with $8-15 \%$ slopes, and Gilpin channery silt loams (GcC2) with $12-20 \%$ slopes (Appendix IVb; Kopas 1973). On the upland sites, soils were moderately deep, moderate to well drained, medium-textured, and underlain by acidic shale and sandstone bedrock (National Park Service 1991). Soils in the meadow region were deep, poor to moderately drained, medium-textured, and were formed from acidic sandstone and shale sediments (Kopas 1973).

The current composition of vegetation in the meadow and more elevated areas has been extensively disturbed and invaded by non-native species (The Western Pennsylvania Conservancy 2003). The upland areas are predominately herbaceous with highly dense to sparse patches of L. morrowii. The lowland areas are mostly herbaceous with sparse patches of L. morrowii and southern arrowwood (Viburnum dentatum). This bush honeysuckle has invaded and dominates the study area, and given that L. morrowii was not present in the 1700s (the period designated as the desired vegetative community for restoration), removing this undesirable species will be the first major action toward reestablishing the historical vegetative condition (Western Pennsylvania Conservancy 2003). Dominant native shrub species on-site include: waxyfruit hawthorne (Crataegus pruinosa), sweet crabapple (Malus coronaria), deerberry (Vaccinium stamineum), and 
Viburnum dentatum. Dominant exotic shrub species included: L. morrowii, Japanese barberry (Berberis thunbergii), and multiflora rose (Rosa multiflora).

\section{Earthworm sampling}

We sampled earthworms in May, August, and September of 2004 and in May, June, and August of 2005. During each sampling month, we randomly selected 10 shrubs of each species (tulip poplar [Liriodendron tulipifera], black locust [Robina pseudoacacia], Viburnum dentatum, and Lonicera morrowii) that were greater than $1.3 \mathrm{~m}$ high and the base of the shrubs were at least $2 \mathrm{~m}$ from a shrub of another species (to decrease the chance that other shrubs might influence the sample). Each shrub was only sampled once during the entire study. We dug fifty $0.015 \mathrm{~m}^{3}$ circular pits measuring a diameter of 30.5 $\mathrm{cm}$ and a depth of $20 \mathrm{~cm}$ (Aplet 1990, James 1991), under 4 shrub/tree species, hereafter referred to as shrubs, and in open spaces.

We drove a circular, open-bottomed metal frame (radius equal to $15.25 \mathrm{~cm}$ ) into the ground to delineate the area (Kourtev et al. 1999). We placed the frame $20 \mathrm{~cm}$ north of the outermost stem. Digging with a shovel, we then placed soil samples in a plastic bag labeled with the location, and took them to a nearby lab. We separated the worms by species in the lab. We euthanized worms by immersion for a few seconds in nearly boiling water (Beyer and Cromartie 1987). To obtain biomass, we counted and weighed worms immediately after blotting on paper towels (Aplet 1990). Digging and handsorting is a commonly used method of effectively collecting epigeic (litter-dwelling) and endogeic (soil-dwelling) earthworms (James and Seastedt 1986, Rosenburg et al. 1986, James 1988, James and Cunningham 1989, Saetre 1998, Edwards et al. 1999, Spurgeon et al. 1999, Kalisz and Powell 2000). To sample anecic species (deep-burrowing) and 
epigeic and endogeic species during hot, dry conditions, we poured a mustard and water suspension into the dug pits to extract worms from their burrows (Lee 1985, Chan and Munro 2001). Two hours before use, we pre-mixed the mustard solution consisting of 23 $\mathrm{g}$ of mustard in $100 \mathrm{ml}$ of water, and then diluted that in 3.11 of water at the time of extraction (L. Heneghan, DePaul University, Chicago, Illinois, personal communication). After pouring the solution on the dug pit, we waited for 20 minutes for anecic worms to evacuate their burrows and rise to the surface (L. Heneghan, DePaul University, Chicago, Illinois, personal communication), whereupon we placed those worms in the labeled plastic bag. We identified morphospecies and preserved a few reproductively active adults of each morphospecies in 10\% formalin for later identification by Dr. Patrick Bohlen, MacArthur Agro-ecology Research Center, Lake Placid, Florida. We differentiated adults from juvenile worms by the presence of a clitellum on adults.

\section{Additional predictive parameters}

Prior to sampling for earthworms, the following measurements were taken from each earthworm-sampling plot for both years: \% cover and identification of each herbaceous plant species ( $\%$ coverage of herbs growing on the area dug), soil chemistry, soil temperature (taken with a soil thermometer), and soil moisture. Soil moisture was obtained by recording the weight before and after drying each soil sample. Soil samples collected from all August 2004 and May 2005 worm plots were sent to a laboratory to determine soil chemistry at each of these plots $(\mathrm{pH}$, available soil organic matter [C], nitrogen $[\mathrm{N}]$, phosphorus $[\mathrm{P}]$, and potassium $[\mathrm{K}])$. 


\section{Statistical analyses}

We used a negative binomial regression model to test effects of shrub species (Viburnum dentatum, Lonicera morrowii, Liriodendron tulipifera, Robinia pseudoacacia, and open spaces) and soil characteristics ( $\mathrm{N}, \mathrm{P}, \mathrm{K}, \mathrm{C}, \mathrm{pH}$, and soil moisture) on earthworms (White and Bennetts 1996, Fox 2003, Fisk et al. 2004). We achieved model fitting using maximum likelihood with the GENMOD procedure in SAS 9.1 (SAS Institute 2003, Block and Stoks 2005). For each model we used logit link and negative binomial errors (Block and Stoks 2005). Due to the high number of zero values in the data from frequently encountering no worms, the data did not meet the Shapiro Wilks' test of normality. Similar to Owen and Galbraith (1989), we transformed the number of worms per square meter collected with a square root transformation so that the skewness and kurtosis were close to 0 (PROC UNIVARIATE; SAS Inst. Inc. 2003). We square-root transformed the following variables to achieve normality: $\mathrm{C}, \mathrm{P}, \mathrm{C}: \mathrm{N}$ ratio, $\mathrm{K}, \mathrm{N}, \mathrm{pH}$, and soil moisture.

We used a model selection approach based on existing literature to determine the soil nutrients that are commonly associated with each earthworm species for samples collected in August 2004 and May 2005. We compared models using Akaike's Information Criterion for small sample sizes ( $\mathrm{AIC}_{\mathrm{c}}$; Burnham and Anderson 2002). We rewarded models that best fit the data (as measured by the log-likelihood, $L$ ) and penalized models for their number of parameters $(K)$ : AIC $=-2 L+2 K$ (Block and Stoks 2005). We ranked the best model based on it having the lowest $\mathrm{AIC}_{\mathrm{c}}$ value, highest Akaike weight $\left(w_{i}\right)$, and the lowest $\operatorname{AIC}_{\mathrm{c}}$ difference $\left(\Delta_{\mathrm{i}}\right)$. The larger the $\Delta_{\mathrm{i}}$, the less likely it was that the model was the best approximating model, given the data (Burnham and 
Anderson 2002). Following Burnham and Anderson's (2002) rules of thumb, we gave models with $\Delta_{\mathrm{i}}$ values that ranged from $0-2$, 'substantial' support as the best approximating model for the data at hand. Additionally, we gave models with $\Delta_{\mathrm{i}}$ values that ranged from 4-7, 'considerably less' support, and models with $\Delta_{\mathrm{i}}>10$ had 'essentially no' support, failing to explain a considerable amount of variation in the data (Burnham and Anderson 2002). When model selection uncertainty existed, we averaged the predicted expected response variable across our models; we were able to reach a robust inference that was not conditional on a single model (Burnham and Anderson 2002).

We developed 6 a priori models that may be responsible for earthworm abundance. The 6 models developed included:

1. Earthworm abundance $(Y)$ is best predicted by the combination of soil total $\mathrm{C}$ (soil organic matter) and P pools (Bohlen et al. 2004b).

$$
Y=\mathrm{C}+\mathrm{P}
$$

2. Earthworm abundance $(Y)$ is best predicted by $\mathrm{C}: \mathrm{N}$ ratios (Bohlen et al. 2004b).

$$
Y=\mathrm{C} / \mathrm{N}
$$

3. Earthworm abundance $(Y)$ is best predicted by $\%$ soil moisture (SM) and soil pH (Liscinsky 1972, Curry 1998).

$$
Y=\mathrm{SM}+\mathrm{pH}
$$

4. Earthworm abundance $(Y)$ is best predicted by a combination of soil total $\mathrm{N}$ pools, P pools, and K pools (Tiwari et al. 1989, Basker et al. 1992).

$$
Y=\mathrm{N}+\mathrm{P}+\mathrm{K}
$$


5. Earthworm abundance $(Y)$ is not directly related to abiotic factors, but is best predicted by shrub/tree species or lack of overstory shrubs/trees (open spaces; $\mathrm{SP})$.

$$
Y=\mathrm{SP}
$$

6. The global model, which includes all factors mentioned (except $\mathrm{C}$ and $\mathrm{N}$ alone), best predicts earthworm abundance $(Y)$.

$$
Y=\mathrm{P}+\mathrm{C} / \mathrm{N}+\mathrm{SM}+\mathrm{pH}+\mathrm{K}+\mathrm{SP}
$$

\section{Results}

\section{Descriptive statistics}

We collected 4 species, all of which are exotic, introduced earthworms from Europe in the Family Lumbricidae (Olson 1980): Eisenia rosea, Lumbricus rubellus, Lumbricus terrestris, and Octolasion tyrtaeum. We collected a total of 1,459 earthworms with a biomass of 330.92 grams from 290 shrub plots and open plots. We did not identify worms to species in May 2004 and therefore, we only have a total count per plot for that month. From 2004 - 2005, E. rosea $(\mathrm{N}=596)$ and O. tyrtaeum $(\mathrm{N}=646)$ comprised the majority of the worms captured (Figure 2). For all shrub species and open spaces at FONE in 2004 and 2005, the average density of E. rosea was 28.1 individuals $/ \mathrm{m}^{2}$ with a standard error (SE) of 4.5, L. rubellus averaged $6.2(\mathrm{SE}=1.1)$, L. terrestris averaged 4.0 $(\mathrm{SE}=0.8)$, and O. tyrtaeum averaged $30.5(\mathrm{SE}=3.7)($ Figure 3$)$. Densities varied widely for E. rosea among shrub species (Table 1) and by month and year (Appendix IVc). There was low to moderate variation in soil variables (mean $\pm \mathrm{SE}$ ) by shrub species (Table 2). 


\section{Model Selection}

\section{Eisenia rosea}

The best model to predict $E$. rosea abundance was the $\{\mathrm{SP}\}$ model, however, the evidence ratio $\left(w_{1} / w_{2}\right)$ for the $\{\mathrm{SP}\}$ over the $2^{\text {nd }}$ ranked model, $\{\mathrm{C} / \mathrm{N}\}$ was 1.49 , with the $2^{\text {nd }}$ ranked model having a $\Delta_{\mathrm{i}}$ value of 0.80 (Table 3 ). There was relatively little support for the best model over the $2^{\text {nd }}$ ranked model, and therefore both are useful to predict densities of this worm species. The remaining 4 models were unlikely to be the best approximating models because the best ranked model was 3.46 times more likely than even the $3^{\text {rd }}$ ranked model.

\section{Lumbricus rubellus}

The best model for predicting where L. rubellus exists was the $\{\mathrm{SP}\}$ model, with the $\{\mathrm{C} / \mathrm{N}\}$ model a poor $2^{\text {nd }}$ (Table 3 ). The remaining 5 models for L. rubellus were given considerably less empirical evidence that they were the best models to predict this species' presence.

\section{Lumbricus terrestris}

The best ranked model to predict the abundance of $L$. terrestris was the $\{\mathrm{SM}+\mathrm{pH}\}$ model, but according to the weight of evidence for each model, the selected best model was not convincingly best; the evidence ratios for $\{\mathrm{SM}+\mathrm{pH}\}$ versus models $\{\mathrm{SP}\}$ and $\{\mathrm{C} / \mathrm{N}\}$ were only about $2\left(w_{\{\mathrm{SM}+\mathrm{pH}\}} / w_{\{\mathrm{SP}\}}=1.93, w_{\{\mathrm{SM}+\mathrm{pH}\}} / w_{\{\mathrm{C} / \mathrm{N}\}}=2.07\right)($ Table 3$)$. The $\{\mathrm{SM}+\mathrm{pH}\}$ model clearly had an edge over the other models, but it was not strong. The remaining 3 models were most likely not the best models to predict the presence of L. terrestris; the $\Delta_{\mathrm{i}}$ 's for the remaining models were $>3.45$ so that the evidence against using these models was reasonably strong. 


\section{Octolasion tyrtaeum}

The $\{\mathrm{C} / \mathrm{N}\}$ model ranked $1^{\text {st }}$ at predicting the abundance of $O$. tyrtaeum. The $\Delta_{\mathrm{i}}$ for the top two models $(\{\mathrm{C} / \mathrm{N}\}$ and $\{\mathrm{C}+\mathrm{P}\})$ differed by $<2$ units $\left(\Delta_{\{\mathrm{C} / \mathrm{N}\}}=0.00\right.$ and $\Delta_{\{\mathrm{C}+\mathrm{P}\}}=$ 1.47). Burnham and Anderson (2002) caution that if models within 2 units of the best model differ by 1 parameter and have essentially the same log-likelihood values as the best model, then the larger model is not actually supported or competitive. This indicated that uncertainty did not exist as to which model was the best model at predicting the presence of O. tyrtaeum; the $\{\mathrm{C} / \mathrm{N}\}$ model was the best fitted model for the data (Table 3). The residual 4 models were unlikely to be the best approximating models because the best ranked model was 5.15 times more likely than even the $3^{\text {rd }}$ ranked model.

\section{Discussion}

For 3 out of the 4 earthworm species (E. rosea, L. rubellus, and L. terrestris), the shrub species (SP) was a powerful predictor at determining earthworm abundance. The information theoretic criterion approach also revealed that for 2 out of the 4 earthworm species, using one best approximating model was not sufficient to predict the presence of those earthworms. Both endogeic species were closely associated with the $\mathrm{C}: \mathrm{N}$ ratio in the soil. Given these earthworm species' unique behavioral characteristics (epigeic, endogeic, and anecic dwellers), the parameters which are predictive of their presence also were unique for each species.

\section{Eisenia rosea}

Eisenia rosea abundance was best predicted by the shrub species (SP) that they occur under and secondly by the $\mathrm{C}: \mathrm{N}$ ratio concentrations in the soil. In this study, E. rosea was tied strongly to L. tulipifera, and to a lesser degree, R. pseudoacacia and V. 
dentatum. The shrub species may be providing the particular litter that the earthworms need for their nutrient requirements (Kourtev et. al. 1999).

This species was negatively associated with the $\mathrm{C}: \mathrm{N}$ ratio and we found about twice as much carbon as nitrogen when E. rosea was present (Table 3). These results agree with previous findings, that the $\mathrm{C}: \mathrm{N}$ ratio of mineral soil was significantly lower in plots containing worms than in plots without worms (Bohlen et al. 2004b) and that exotic worms increased mobilization and leaching of $\mathrm{N}$ from the soil (Suárez et al. 2003). These results are further supported by the $\mathrm{C}: \mathrm{N}$ ratio associated with a native, endogeic earthworm species (i.e., Diplocardia spp.); in its presence, the soil C:N ratio was consistently greater than in the presence of an exotic endogeic species (Callaham et al. 2001). We suggest this equation be used $(Y=1.8274-[2.3722 \times(\mathrm{C} / \mathrm{N})])$ to estimate the number of $E$. rosea per square meter that will be present in similar study areas.

\section{Lumbricus rubellus}

Shrub species was the best predictor of L. rubellus abundance. Lumbricus rubellus was strongly tied to L. tulipifera and to a lesser degree R. pseudoacacia and L. morrowii. Lumbricus rubellus was the only epi-endogeic species found in this study and our data suggest that the palatability of the litter layer (vegetative debris from a given shrub) may have driven the presence of this species. This earthworm ingests organic matter from the upper layers of the soil (Suárez et al. 2003). Given that exotic epigeic earthworms greatly deplete the mass of the surface organic horizons and alter nutrient cycling and loss (Groffman et al. 2004), restorationists can promote the growth of shrub species that are not associated with exotic worms. Encroaching exotic earthworm invasions may 
potentially be curbed by planting $V$. dentatum, a native shrub that did not attract the exotic and invasive L. rubellus.

\section{Lumbricus terrestris}

The SM and $\mathrm{pH}$ parameters were the strongest factors for predicting the abundance of $L$. terrestris. The factors that drove the presence of this species varied between $\mathrm{SM}, \mathrm{pH}, \mathrm{SP}$, and $\mathrm{C} / \mathrm{N}$ from sample to sample and indicate that these factors combined may best predict L. terrestris densities. The following equation was developed by model averaging and can be used to estimate the number of L. terrestris per square meter that will be present $Y$ $=2.9044-(0.0596 \times \mathrm{SM})-(1.1602 \times \mathrm{pH})-(1.7141 \times \mathrm{C} / \mathrm{N})$. In conjunction with using

the model, we note that underneath L. tulipifera and L. morrowii we found the greatest abundances of $L$. terrestris.

This earthworm appeared to be negatively associated with a high $\mathrm{pH}$, so that acidic soils occurred with this species, rather than basic soils (Table 3). Kourtev et al. (1999) suggested that exotic earthworms and exotic plants fix the soil to a higher $\mathrm{pH}$ and lower $\mathrm{C}$ and $\mathrm{N}$ concentrations to reinforce each other's population growth. If the phenomenon proposed by Kourtev et al. (1999) was occurring at FONE, where $L$. terrestris created soil conditions (higher $\mathrm{pH}$, lower $\mathrm{C}: \mathrm{N}$ ratio) that promoted L. morrowii and vice versa, then restoration efforts aimed at removing the exotic plants may have a long-lasting problem in the earthworms that will remain in the soil after the exotic plants are removed. The exotic earthworms may continue to "prepare" the soil and subsequently narrow the filter for potential re-colonizers to FONE; the exotic invasive vegetation will be able to out-compete any less tolerable native vegetation. These exotic earthworms are using resources that could otherwise be used by other organisms, but they 
also could be increasing the availability of scarce resources (Aplet 1990). We

recommend that further studies investigate the specific impacts to native and exotic vegetation from the influence of exotic worms, but specifically L. terrestris as this species is the most widely distributed exotic worm species in North America and is active in all seasons of the year (Olson 1980).

\section{Octolasion tyrtaeum}

Evidence suggests that the $\mathrm{C}: \mathrm{N}$ ratio best predicted the presence of $O$. tyrtaeum. There was about three times as much $\mathrm{C}$ as $\mathrm{N}$ when O. tyrtaeum was present (Table 3). Contrary to the findings of Callaham et al. (2001), the C:N ratio was positively associated with $O$. tyrtaeum, not decreased in the soil with O. tyrtaeum. For every one unit increase in the $\mathrm{C} / \mathrm{N}$ ratio, the earthworm count per square meter should have increased by 2.83 according to the predictive equation. We recommend use of the following equation to estimate the number of O. tyrtaeum per square meter that will be present $Y=0.65+(2.83 \times(\mathrm{C} / \mathrm{N}))$. Whether these endogeic worms increased the mineral soil $\mathrm{C}$ and $\mathrm{N}$ into usable forms for plants and other organisms, or depleted the available $\mathrm{C}$ and $\mathrm{N}$ for native organisms, remains a question for future research (Callaham et al. 2001).

\section{Restoration Implications}

We developed these predictive equations to estimate the densities of earthworm species, so that we gain a better understanding of plant and soil characteristics that are associated with earthworm species in an area dominated by exotic shrubs. For the earthworm species at FONE, L. tulipifera or R. pseudoacacia supported the highest average density rather than L. morrowii. However, evidence in this study also shows that exotic earthworms are not discouraged from existing in soil underneath exotic plant species, 
namely L. morrowii. Earthworms are generally thought to provide beneficial changes to soil structure, nutrient dynamics, and plant growth; however, exotic earthworms may have undesirable effects on other organisms and soil processes in their new habitats (Hendrix and Bohlen 2002). Bohlen et al. (2004b) warns that invading exotic earthworms can rapidly decrease the abundance and diversity of native tree seedlings. At FONE, it remains unknown as to whether these exotic earthworms will hinder or enhance native shrub and tree growth after the exotic L. morrowii is removed for the restoration at Fort Necessity National Battlefield. We did find lower abundances of $L$. rubellus, $L$. terrestris, and O. tyrtaeum under V. dentatum than under $L$. morrowii. This indicates that planting of $V$. dentatum may assist in reducing exotic earthworm abundance in this site. Ongoing documentation and monitoring through the future restoration process is needed to determine the earthworm species that will remain, immigrate, or emigrate into the newly disturbed, L. morrowii-free site.

\section{Acknowledgments}

This work was funded by the National Park Service and Fort Necessity National Battlefield in Farmington, Pennsylvania. We thank Connie A. Ranson and John W. Edwards for reviewing this manuscript. Jason Love, Mark Hepner, Jason Alexander, Jennifer Love, and Robbie Edalgo from West Virginia University (WVU) assisted with field work. We thank Patrick Bohlen of the MacArthur Agro-ecology Research Center for identifying our earthworm specimens. We appreciate the help from George Seidel for statistical guidance. This is scientific article number XXXX of the WVU Agricultural and Forestry Experimental Station. 


\section{References}

Allen MF, Allen EB, Zink TA, Harney S, Yoshida LC, Siguenza C, Edwards F, Hinkson C, Rillig M, Bainbridge D, Doljanin C, and MacAller R (1999) Soil Microorganisms. In: Walker LR (ed) Ecosystems of disturbed ground, pp 521544. Elsevier, Amsterdam

Aplet GH (1990) Alteration of earthworm community biomass by the alien Myrica faya in Hawai'i. Oecologia 82: 414-416

Basker A, Macgregor AN and Kirkman JH (1992) Influence of soil ingestion by earthworms on the availability of potassium in soil: an incubation experiment. Biology and Fertility of Soils 14: 300-303

Beyer WN and Cromartie EJ (1987) A survey of $\mathrm{Pb}, \mathrm{Cu}, \mathrm{Cd}, \mathrm{Cr}$, As, and $\mathrm{Se}$ in earthworms and soil from diverse sites. Environmental Monitoring and Assessment 8: 27-36

Block MD and Stoks R (2005) Fitness effects from egg to reproduction: bridging the life history transition. Ecology 86: 185-197

Bohlen PJ, Scheu S, Hale CM, McLean MA, Migge S, Groffman PM and Parkinson D (2004a) Non-native invasive earthworms as agents of change in northern temperate forests. Frontiers in Ecology and the Environment 2: 427-435

Bohlen PJ, Pelletier DM, Groffman PM, Fahey TJ and Fisk MC (2004b) Influence of earthworm invasion on redistribution and retention of soil carbon and nitrogen in northern temperate forests. Ecosystems 7: 13-27 
Burnham KP and Anderson DR (2002) Model selection and inference: a practical information-theoretic approach. Second Edition. Springer-Verlag, New York, NY, $488 \mathrm{pp}$

Callaham MA Jr, Blair JM and Hendrix PF (2001) Different behavioral patterns of the earthworms Octolasion tyrtaeum and Diplocardia spp. in tallgrass prairie soils: potential influences on plant growth. Biology and Fertility of Soils 34: 4956

Chan K. and Munro K (2001) Evaluating mustard extracts for earthworm sampling. Pedobiologia 45: 272-278

Edwards GR, Crawley MJ and Heard MS (1999) Factors influencing molehill distribution in grassland: implications for controlling the damage caused by molehills. Journal of Applied Ecology 36: 434-442

Edwards GR. and Bohlen PJ (1996) Biology and ecology of earthworms. Third Edition. Chapman and Hall, London, $426 \mathrm{pp}$

Fisk MC, Fahey TJ, Groffman PM and Bohlen PJ (2004) Earthworm invasion, fine-root distributions, and soil respiration in north temperate forests. Ecosystems $7: 55-62$

Fox CA, Jarvis I, Hehan-Pelletier V, Dalpe Y, Clapperton J, Prevost D, Joschko M and Lentzsch P (2003) Progress towards developing a soil biodiversity indicator for Canada. OECD Expert Meeting on Soil Erosion and Soil Biodiversity Indicators. Rome, Italy, $16 \mathrm{pp}$

Gregory TR and Hebert PDN (2002) Genome-size estimates for some oligochaete annelids. Canadian Journal of Zoology 80: 1485-1489 
Groffman PM, Bohlen PJ, Fisk MC, and Fahey TJ (2004) Exotic earthworm invasion and microbial biomass in temperate forest soils. Ecosystems 7: 45-54

Halle S and Fattorini M (2004) Advances in restoration ecology: insights from aquatic and terrestrial ecosystems. In: Temperton VM, Hobbs RJ, Nuttle T, and Halle S (eds) Assembly rules and restoration ecology, pp 10-33. Island Press, Washington, DC

Hendrix PF and Bohlen PJ (2002) Exotic earthworm invasions in North America: ecological and policy implications. Bioscience 52: 801-811

James SW (1988) The postfire environment and earthworm populations in tallgrass prairie. Ecology 69: 476-483

------- (1991) Soil, nitrogen, phosphorus, and organic matter processing by earthworms in tallgrass prairie. Ecology 72: 2101-2109

James SW and Cunningham MR (1989) Feeding ecology of some earthworms in Kansas Tallgrass Prairie. American Midland Naturalist 121: 78-83

James SW and Seastedt TR (1986) Nitrogen mineralization by native and introduced earthworms: effects on bluestem growth. Ecology 67: 1094-1097

Kalisz PJ and Dotson DB (1989) Land-use history and the occurrence of exotic earthworms in the mountains of eastern Kentucky. American Midland Naturalist 122: $288-297$

Kalisz PJ and Powell JE (2000) Invertebrate macrofauna in soils under old growth and minimally disturbed second growth forests of the Appalachian Mountains of Kentucky. American Midland Naturalist 144: 297-307 
Kalisz PJ and Wood HB (1995) Native and exotic earthworms in wildland ecosystems. In: Hendrix PF (ed) Earthworm ecology and biogeography in North America, pp 117-126. CRC Press, Boca Raton, FL

Kopas FA (1973) Soil survey of Fayette County, Pennsylvania. United States Department of Agriculture/Soil Conservation Service, Washington, DC, --- pp

Kourtev PS, Huang WZ and Ehrenfeld JG (1999) Differences in earthworm densities and nitrogen dynamics in soils under exotic and native plant species. Biological Invasions 1: 237-245

Lee KE (1985) Earthworms, their ecology and relationships with soils and land use. Academic Press. Orlando, FL, 411 pp

Mooney HA and Hobbs RJ (2000) Introduction. In: Mooney HA and Hobbs RJ (eds) Invasive species in a changing world, pp xiii-xv. Island Press, Washington, DC Morrison ML (2002) Sampling methods: Wildlife Restoration. Island Press, Washington, DC, 209 pp

National Park Service (1991) General Management Plan/Development Concept Plan/Interpretive Prospectus: Fort Necessity National Battlefield. Prepared by the Denver Service Center, 92 pp

Nyboer R (1992) Vegetation management guideline: bush honeysuckles - tatarian, Morrow's, Belle, and Amur honeysuckle (Lonicera tatarica L., L. morrowii Gray, L. x bella Zabel, and L. maackii [Rupr.] Maxim.). Natural Areas Journal 12: 218219

Olson HW (1980) Earthworms of Ohio. Ohio Biological Survey 47-90 
Paoletti MG and Bressan M (1996) Soil invertebrates as bioindicators of human disturbance. Critical Reviews in Plant Sciences 15: 21-62

Parmelee RW, Bohlen PJ and Blair JM (1998) Earthworms and nutrient cycling processes: integrating across the ecological hierarchy. In: Edwards CA (ed) Earthworm Ecology pp 123-143. St. Lucie Press, Boca Raton, FL

Rehder A (1940) A manual of cultivated trees and shrubs. Second edition. MacMillan Publishing Company, New York, NY

Rosenberg DM, Danks HV and Lehmkuhl DM (1986) Importance of insects in environmental impact assessment. Environmental Management 10: 773-783

Saetre P (1998) Decomposition, microbial community structure, and earthworm effects along a birch-spruce soil gradient. Ecology 79: 834-846

SAS (2003) Statistical Analysis System, version 9.1. SAS: Cary, NC

Scheu S and Schulz E (1996) Secondary succession, soil formation and development of a diverse community of oribatids and saprophagous soil macro-invertebrates. Biodiversity and Conservation 5: 235-250

Spurgeon DJ and Hopkin SP (1999) Seasonal variation in the abundance, biomass and biodiversity of earthworms in soils contaminated with metal emissions from a primary smelting works. Journal of Applied Ecology 36: 173-183

Suárez ER, Pelletier DM, Fahey TJ, Groffman PM, Bohlen PJ, and Fisk MC (2003) Effects of exotic earthworms on soil phosphorus cycling in two broadleaf temperate forests. Ecosystems 7: 28-44 
Tiwari SC, Tiwari BK and Mishra RR (1989) Microbial populations, enzyme activities and nitrogen-phosphorus-potassium enrichment in earthworm casts and in the surrounding soil of a pineapple plantation. Biology and Fertility of Soils 8: 178182

Batcher MS Stiles SA Element Stewardship Abstract for the Bush Honeysuckles, The Nature Conservancy. http://tncweeds.ucdavis.edu/esadocs/documnts/loni_sp.html. Accessed February 10,2004

Western Pennsylvania Conservancy (2003) Plant community mapping and surveys for species of special concern at Allegheny Portage Railroad National Historic Site, Johnstown Flood National Memorial, Fort Necessity National Battlefield, and Friendship Hill National Historic Site, 82pp

White GC and Bennetts RE (1996) Analysis of frequency count data using the negative binomial distribution. Ecology 77: 2549-2557

Williams CE (1999) Fruits of alien shrubs and deer mice: a test of the persistent fruit defense hypothesis. Journal of the Pennsylvania Academy of Science 73: 33-37 
Table 1. Mean earthworm densities (number of worms per square meter) and standard errors (SE) for each earthworm species captured underneath the various shrub/tree species at Fort Necessity National Battlefield in Fayette County, Pennsylvania, USA in August, and September of 2004 and in May, June, and August of 2005.

\begin{tabular}{|c|c|c|c|c|c|c|c|c|c|c|}
\hline \multirow[b]{4}{*}{ Earthworm Species ${ }^{a}$} & \multicolumn{8}{|c|}{ Plot Location $^{b}$} & & \\
\hline & \multirow{2}{*}{\multicolumn{2}{|c|}{$\begin{array}{c}\text { Liriodendron } \\
\text { tulipifera }\end{array}$}} & \multirow{2}{*}{\multicolumn{2}{|c|}{$\begin{array}{l}\text { Lonicera } \\
\text { morrowii }\end{array}$}} & \multirow{2}{*}{\multicolumn{2}{|c|}{$\begin{array}{l}\text { Open } \\
\text { Spaces }\end{array}$}} & \multirow{2}{*}{\multicolumn{2}{|c|}{$\begin{array}{c}\text { Robinia } \\
\text { pseudoacacia }\end{array}$}} & \multirow{2}{*}{\multicolumn{2}{|c|}{$\begin{array}{l}\text { Viburnum } \\
\text { dentatum }\end{array}$}} \\
\hline & & & & & & & & & & \\
\hline & $\bar{x}$ & $\mathrm{SE}$ & $\bar{x}$ & $\mathrm{SE}$ & $\overline{\bar{x}}$ & $\mathrm{SE}$ & $\bar{x}$ & $\mathrm{SE}$ & $\bar{x}$ & $\mathrm{SE}$ \\
\hline Eisenia rosea & 67.1 & 21.3 & 17.7 & 4.6 & 16.3 & 4.6 & 23.5 & 6.4 & 23.3 & 7.3 \\
\hline Lumbricus rubellus & 17.5 & 5.0 & 5.7 & 1.6 & 2.4 & 1.2 & 5.3 & 1.9 & 2.4 & 0.9 \\
\hline Lumbricus terrestris & 7.7 & 2.6 & 4.0 & 1.2 & 3.3 & 1.4 & 3.1 & 1.8 & 2.6 & 1.4 \\
\hline Octolasion tyrtaeum & 41.6 & 14.3 & 31.6 & 6.6 & 25.4 & 6.5 & 30.2 & 6.8 & 25.8 & 6.6 \\
\hline
\end{tabular}

${ }^{\text {a }}$ Total worms counted in all plots $(N=290)$ : Eisenia rosea, $n=596$ worms; Lumbricus rubellus, $n=132$ worms; Lumbricus terrestris, $n=85$ worms; Octolasion tyrtaeum, $n=$ 646 worms.

${ }^{\mathrm{b}}$ Total plots dug for each shrub summed across years: Liriodendron tulipifera, $n=50$

plots; Lonicera morrowii, $n=65$ plots; open spaces, $n=62$ plots; Robinia pseudoacacia, $n=49$ plots; Viburnum dentatum, $n=64$ plots. 
Table 2. Means and standard errors of soil variables and earthworms (number/square meter) associated with each shrub/tree species and in open spaces at Fort Necessity National Battlefield in Fayette County, Pennsylvania, USA from plots in August 2004 and May 2005.

\begin{tabular}{|c|c|c|c|c|c|c|c|c|c|c|}
\hline & & & & Shrub & Specic & & & & & \\
\hline & & nicera & Lir & odendron & & ben & & binia & & iburnum \\
\hline & & orrowii & & Ilipifera & & aces & pseud & loacacia & & entatum \\
\hline & & $\eta=30)$ & & $n=20)$ & & = 29) & & $=20)$ & & $\eta=29)$ \\
\hline Variable & $\overline{\mathrm{x}}$ & SE & $\overline{\bar{x}}$ & SE & $\overline{\mathrm{x}}$ & $\mathrm{SE}$ & $\overline{\mathrm{x}}$ & SE & $\overline{\mathrm{x}}$ & SE \\
\hline Soil Nutrient $^{\mathbf{b}}$ & & & & & & & & & & \\
\hline $\mathrm{C}$ & 4.98 & 0.26 & 5.41 & 0.36 & 4.95 & 0.22 & 5.79 & 0.36 & 5.03 & 0.16 \\
\hline $\mathrm{P}$ & 13.60 & 0.70 & 10.95 & 0.71 & 11.69 & 0.58 & 13.10 & 0.82 & 12.69 & 0.78 \\
\hline $\mathrm{C} / \mathrm{N}$ & 0.05 & 0.00 & 0.05 & 0.00 & 0.05 & 0.00 & 0.06 & 0.00 & 0.05 & 0.00 \\
\hline SM & 22.28 & 0.76 & 24.99 & 0.79 & 22.40 & 1.10 & 23.61 & 0.86 & 23.53 & 0.54 \\
\hline $\mathrm{pH}$ & 5.30 & 0.04 & 5.44 & 0.15 & 5.35 & 0.06 & 5.14 & 0.13 & 5.22 & 0.04 \\
\hline $\mathrm{N}$ & 96.80 & 1.87 & 99.80 & 2.32 & 97.07 & 1.58 & 102.50 & 2.23 & 98.48 & 1.26 \\
\hline $\mathrm{K}$ & 80.77 & 5.08 & 97.55 & 7.67 & 67.03 & 5.08 & 99.50 & 13.43 & 71.41 & 3.58 \\
\hline Worm Species ${ }^{c}$ & & & & & & & & & & \\
\hline Eisenia rosea & 13.23 & 5.22 & 91.70 & 46.02 & 23.55 & 8.88 & 40.35 & 13.06 & 36.79 & 15.18 \\
\hline Lumbricus rubellus & 11.43 & 3.01 & 23.20 & 11.13 & 2.86 & 1.58 & 11.65 & 4.13 & 2.86 & 1.25 \\
\hline Lumbricus terrestris & 4.13 & 1.76 & 4.80 & 2.48 & 2.86 & 1.58 & 1.40 & 0.96 & 0.48 & 0.48 \\
\hline Octolasion tyrtaeum & 27.83 & 6.46 & 25.30 & 10.62 & 31.10 & 8.36 & 34.90 & 10.62 & 27.79 & 8.29 \\
\hline
\end{tabular}

\footnotetext{
${ }^{a}$ Sample size represents the 2 months that soil nutrients were analyzed, not the entire 6 months of worm collection.
} 
Table 2. continued.

${ }^{\mathrm{b}} \mathrm{C}=$ carbon (soil organic matter; \% of organic matter in the soil); $\mathrm{P}=$ phosphorus (parts per million $[\mathrm{ppm}]$ ); $\mathrm{C} / \mathrm{N}=$ carbon (soil organic matter): nitrogen (estimated nitrogen upon release $)$ ratio; $\mathrm{SM}=$ soil moisture $(\%$ from $[([$ wet weight - dry weight $] /$ wet weight $) \times$ $100]) ; \mathrm{pH}=\mathrm{pH}\left(\mathrm{H}_{2} \mathrm{O} 1: 1\right) ; \mathrm{K}=\operatorname{potassium}(\mathrm{ppm})$.

${ }^{\mathrm{c}}$ Total worms counted in all plots $(N=128)$ : Eisenia rosea, $n=350$ worms; Lumbricus rubellus, $n=88$ worms; Lumbricus terrestris, $n=25$ worms; Octolasion tyrtaeum, $n=$ 274 worms. 
Table 3. Summary of a priori models to predict abundance of earthworms at Fort Necessity National Battlefield in Fayette County, Pennsylvania, USA from May 2004 and August 2005.

\begin{tabular}{|c|c|c|c|c|c|c|c|c|}
\hline Model $^{\mathrm{a}}$ & Equation $\left(Y=\right.$ no. worms $\left./ \mathrm{m}^{2}\right)$ & $\log ^{b}$ & $K^{\mathrm{b}}$ & $\mathrm{AIC}_{\mathrm{c}}^{\mathrm{b}}$ & $\Delta_{\mathrm{i}}^{\mathrm{b}}$ & $\mathrm{w}_{\mathrm{i}}^{\mathrm{b}}$ & Chi-square value & Chi-square value $/ d f^{\mathrm{d}}$ \\
\hline \multicolumn{9}{|l|}{ Eisenia rosea $^{\mathrm{C}}$} \\
\hline$\{\mathrm{C}, \mathrm{P}\}$ & $0.09-(0.01 \times \mathrm{C})-(0.19 \times \mathrm{P})$ & 330.45 & 4 & -652.58 & 2.48 & 0.13 & 127.90 & 1.02 \\
\hline$\{\mathrm{C} / \mathrm{N}\}$ & $1.83-(2.37 \times \mathrm{C} / \mathrm{N})$ & 330.23 & 3 & -654.26 & 0.80 & 0.29 & 128.51 & 1.02 \\
\hline$\{\mathrm{SM}, \mathrm{pH}\}$ & $0.92+(0.27 \times \mathrm{SM})-(0.40 \times \mathrm{pH})$ & 330.20 & 4 & -652.08 & 2.99 & 0.10 & 117.81 & 0.96 \\
\hline$\{\mathrm{N}, \mathrm{P}, \mathrm{K}\}$ & $1.41+(0.06 \times \mathrm{N})-(0.20 \times \mathrm{P})-(0.01 \times \mathrm{K})$ & 330.48 & 5 & -650.46 & 4.60 & 0.04 & 127.71 & 1.03 \\
\hline$\{\mathrm{SP}\}$ & $\begin{array}{l}1.39-(0.67 \times \mathrm{M})+(0.40 \times \mathrm{T})-(0.38 \times \mathrm{O})+(0.08 \times \mathrm{B}) \\
+(0.00 \times \mathrm{S})\end{array}$ & 335.00 & 7 & -655.06 & 0.00 & 0.44 & 123.60 & 1.00 \\
\hline$\{\mathrm{P}, \mathrm{C} / \mathrm{N}, \mathrm{SM}, \mathrm{pH}, \mathrm{K}, \mathrm{SP}\}$ & $\begin{array}{l}3.10-(0.04 \times \mathrm{P})-(7.56 \times \mathrm{C} / \mathrm{N})+(0.31 \times \mathrm{SM})- \\
(0.37 \times \mathrm{pH})-(0.06 \times \mathrm{K})-(0.56 \times \mathrm{M})+(0.49 \times \mathrm{T})- \\
(0.37 \times \mathrm{O})+(0.25 \times \mathrm{B})+(0.00 \times \mathrm{S})\end{array}$ & 335.43 & 12 & -644.14 & 10.92 & 0.00 & 118.29 & 1.02 \\
\hline \multicolumn{9}{|l|}{ Lumbricus rubellus $^{\mathrm{c}}$} \\
\hline$\{\mathrm{C}, \mathrm{P}\}$ & $1.04-(0.30 \times \mathrm{C})+(0.03 \times \mathrm{P})$ & -5.00 & 4 & 18.34 & 5.63 & 0.04 & 112.19 & 0.90 \\
\hline$\{\mathrm{C} / \mathrm{N}\}$ & $1.63-(5.17 \times \mathrm{C} / \mathrm{N})$ & -4.97 & 3 & 16.14 & 3.44 & 0.12 & 111.94 & 0.89 \\
\hline$\{\mathrm{SM}, \mathrm{pH}\}$ & $0.57+(0.08 \times \mathrm{SM})-(0.21 \times \mathrm{pH})$ & -3.89 & 4 & 16.11 & 3.41 & 0.12 & 110.70 & 0.90 \\
\hline$\{\mathrm{N}, \mathrm{P}, \mathrm{K}\}$ & $1.32-(0.14 \times \mathrm{N})+(0.01 \times \mathrm{P})+(0.06 \times \mathrm{K})$ & -4.94 & 5 & 20.37 & 7.67 & 0.01 & 111.31 & 0.90 \\
\hline$\{\mathrm{SP}\}$ & $\begin{array}{l}-0.25+(1.04 \times \mathrm{M})+(1.23 \times \mathrm{T})-(0.11 \times 0)+ \\
(0.96 \times \mathrm{B})+(0.00 \times \mathrm{S})\end{array}$ & 1.12 & 7 & 12.70 & 0.00 & 0.68 & 118.97 & 0.97 \\
\hline
\end{tabular}


Table 3. continued.

\begin{tabular}{|c|c|c|c|c|c|c|c|c|}
\hline Model $^{\mathrm{a}}$ & Equation $\left(Y=\right.$ no. worms $\left./ \mathrm{m}^{2}\right)$ & $\log ^{b}$ & $K^{b}$ & $\mathrm{AIC}_{\mathrm{c}}^{\mathrm{b}}$ & $\Delta_{\mathrm{i}}^{\mathrm{b}}$ & $\mathrm{w}_{\mathrm{i}}^{\mathrm{b}}$ & Chi-square value & Chi-square value $/ d f^{\mathrm{d}}$ \\
\hline$\{\mathrm{P}, \mathrm{C} / \mathrm{N}, \mathrm{SM}, \mathrm{pH}, \mathrm{K}, \mathrm{SP}\}$ & $\begin{array}{l}1.28-(0.05 \times \mathrm{P})-(6.31 \times \mathrm{C} / \mathrm{N})-(0.09 \times \mathrm{SM})+ \\
(0.52 \times \mathrm{pH})-(0.08 \times \mathrm{K})+(1.04 \times \mathrm{M})+(1.36 \times \mathrm{T})- \\
(0.32 \times \mathrm{O})+(0.94 \times \mathrm{B})+(0.00 \times \mathrm{S})\end{array}$ & 3.13 & 12 & 20.49 & 7.79 & 0.01 & 114.23 & 0.98 \\
\hline \multicolumn{9}{|l|}{ Lumbricus terrestris $^{\mathrm{c}}$} \\
\hline$\{\mathrm{C}, \mathrm{P}\}$ & $-0.24-(0.23 \times \mathrm{C})+(0.09 \times \mathrm{P})$ & -76.19 & 4 & 160.71 & 3.45 & 0.08 & 58.35 & 0.47 \\
\hline$\{\mathrm{C} / \mathrm{N}\}$ & $0.34-(3.43 \times \mathrm{C} / \mathrm{N})$ & -76.26 & 3 & 158.52 & 1.46 & 0.21 & 56.75 & 0.45 \\
\hline$\{\mathrm{SM}, \mathrm{pH}\}$ & $5.47-(0.12 \times \mathrm{SM})-(2.32 \times \mathrm{pH})$ & -74.46 & 4 & 157.26 & 0.00 & 0.44 & 57.54 & 0.47 \\
\hline$\{\mathrm{N}, \mathrm{P}, \mathrm{K}\}$ & $1.96-(0.27 \mathrm{~N})+(0.07 \times \mathrm{P})+(0.01 \times \mathrm{K})$ & -75.97 & 5 & 162.44 & 5.18 & 0.03 & 58.38 & 0.47 \\
\hline$\{\mathrm{SP}\}$ & $\begin{array}{l}0.01+(1.45 \times \mathrm{M})+(1.52 \times \mathrm{T})+(0.98 \times \mathrm{O})+ \\
(0.72 \times \mathrm{B})+(0.00 \times \mathrm{S})\end{array}$ & -71.81 & 7 & 158.58 & 1.32 & 0.23 & 57.39 & 0.47 \\
\hline$\{\mathrm{P}, \mathrm{C} / \mathrm{N}, \mathrm{SM}, \mathrm{pH}, \mathrm{K}, \mathrm{SP}\}$ & $\begin{array}{l}7.07-(0.19 \times \mathrm{P})-(4.30 \times \mathrm{C} / \mathrm{N})+(0.18 \times \mathrm{SM})- \\
(3.25 \times \mathrm{pH})-(0.05 \times \mathrm{K})+(1.58 \times \mathrm{M})+(1.65 \times \mathrm{T})+ \\
(1.05 \times \mathrm{O})+(0.80 \times \mathrm{B})+(0.00 \times \mathrm{S})\end{array}$ & -69.38 & 12 & 165.52 & 8.25 & 0.01 & 59.73 & 0.51 \\
\hline \multicolumn{9}{|l|}{ Octolasion tyrtaeum ${ }^{\mathrm{c}}$} \\
\hline$\{\mathrm{C}, \mathrm{P}\}$ & $0.13+(0.17 \times \mathrm{C})+(0.22 \times \mathrm{P})$ & 299.58 & 4 & -590.84 & 1.47 & 0.28 & 185.67 & 1.48 \\
\hline$\{\mathrm{C} / \mathrm{N}\}$ & $0.65+(2.83 \times \mathrm{C} / \mathrm{N})$ & 299.25 & 3 & -592.31 & 0.00 & 0.59 & 185.87 & 1.48 \\
\hline$\{\mathrm{SM}, \mathrm{pH}\}$ & $4.88+(0.01 \times \mathrm{SM})-(1.59 \times \mathrm{pH})$ & 293.21 & 4 & -578.11 & 14.20 & 0.00 & 181.86 & 1.48 \\
\hline$\{\mathrm{N}, \mathrm{P}, \mathrm{K}\}$ & $-0.75+(0.10 \times \mathrm{N})+(0.21 \times \mathrm{P})+(0.04 \times \mathrm{K})$ & 299.76 & 5 & -589.03 & 3.28 & 0.12 & 186.87 & 1.51 \\
\hline$\{\mathrm{SP}\}$ & $\begin{array}{l}1.23+(0.12 \times \mathrm{M})-(0.08 \times \mathrm{T})+(0.14 \times \mathrm{O})+ \\
(0.11 \times \mathrm{B})+(0.00 \times \mathrm{S})\end{array}$ & 299.33 & 7 & -583.73 & 8.58 & 0.01 & 179.72 & 1.46 \\
\hline
\end{tabular}




\begin{tabular}{|c|c|c|c|c|c|c|c|c|}
\hline Model $^{\mathrm{a}}$ & Equation $\left(Y=\right.$ no. worms $\left./ \mathrm{m}^{2}\right)$ & $\log ^{b}$ & $K^{b}$ & $\mathrm{AIC}_{\mathrm{c}}^{\mathrm{b}}$ & $\Delta_{\mathrm{i}}^{\mathrm{b}}$ & $\mathrm{w}_{\mathrm{i}}^{\mathrm{b}}$ & Chi-square value & Chi-square value/df $f^{\mathrm{d}}$ \\
\hline$\{\mathrm{P}, \mathrm{C} / \mathrm{N}, \mathrm{SM}, \mathrm{pH}, \mathrm{K}, \mathrm{SP}\}$ & $\begin{array}{l}3.15+(0.20 \times \mathrm{P})+(0.78 \times \mathrm{C} / \mathrm{N})+(0.02 \times \mathrm{SM})- \\
(1.42 \times \mathrm{pH})+(0.05 \times \mathrm{K})+(0.05 \times \mathrm{M})-(0.13 \times \mathrm{T})+ \\
(0.23 \times \mathrm{O})-(0.15 \times \mathrm{B})+(0.00 \times \mathrm{S})\end{array}$ & 293.86 & 12 & -561.01 & 31.30 & 0.00 & 174.27 & 1.50 \\
\hline
\end{tabular}

${ }^{\mathrm{a}} \mathrm{P}=$ phosphorus (parts per million $\left.[\mathrm{ppm}]\right) ; \mathrm{C} / \mathrm{N}=$ carbon (soil organic matter): nitrogen (estimated nitrogen upon release) ratio; $\mathrm{SM}=$ soil moisture $(\%$ from $[([$ wet weight - dry weight $] /$ wet weight $) \times 100]) ; \mathrm{pH}=\mathrm{pH}\left(\mathrm{H}_{2} \mathrm{O} 1: 1\right) ; \mathrm{K}=$ potassium $(\mathrm{ppm}) ; \mathrm{SP}=$ species of shrub/tree $(\mathrm{M}=$ Morrow's honeysuckle [Lonicera morrowii], $\mathrm{T}=$ tulip poplar [Liriodendron tulipifera], $\mathrm{B}=\mathrm{black}$ locust [Robinia pseudoacacia], $\mathrm{S}=$ southern arrowwood [Viburnum dentatum], $\mathrm{O}=$ open spaces).

${ }^{\mathrm{b}}$ Log-likelihood, number of parameters $(K), \operatorname{AIC}$, differences $\left(\Delta_{\mathrm{i}}\right)$, and Akaike weights $\left(w_{i}\right)$. The models with the minimum AICc are shown in bold.

${ }^{\mathrm{c}}$ Square-root transformations included : Eisenia rosea $(n=128$ plots $)$ wormssqrt $=\sqrt{ }($ worms +0.10$) ;$ Lumbricus rubellus $(n=126$ plots $)$ wormssqrt $=\sqrt{ }($ worms +0.01$) ;$ Lumbricus terrestris $(n=126$ plots $)$ wormssqrt $=\sqrt{ }($ worms +0.01$)$; and Octolasion tyrtaeum $(n$ $=128$ plots $)$ wormssqrt $=\sqrt{ }($ worms $)$.

${ }^{\mathrm{d}}$ The Chi-square value/df is an estimate of the dispersion in assessing the Goodness of Fit for each model, given the data. If the estimate of dispersion is not near 1 , then the data may be overdispersed (if the dispersion estimate is greater than 1) or underdispersed (if the dispersion estimate is less than 1). The model is well fit to the data if the Chi-square value is approximately equal to the $d f$. 


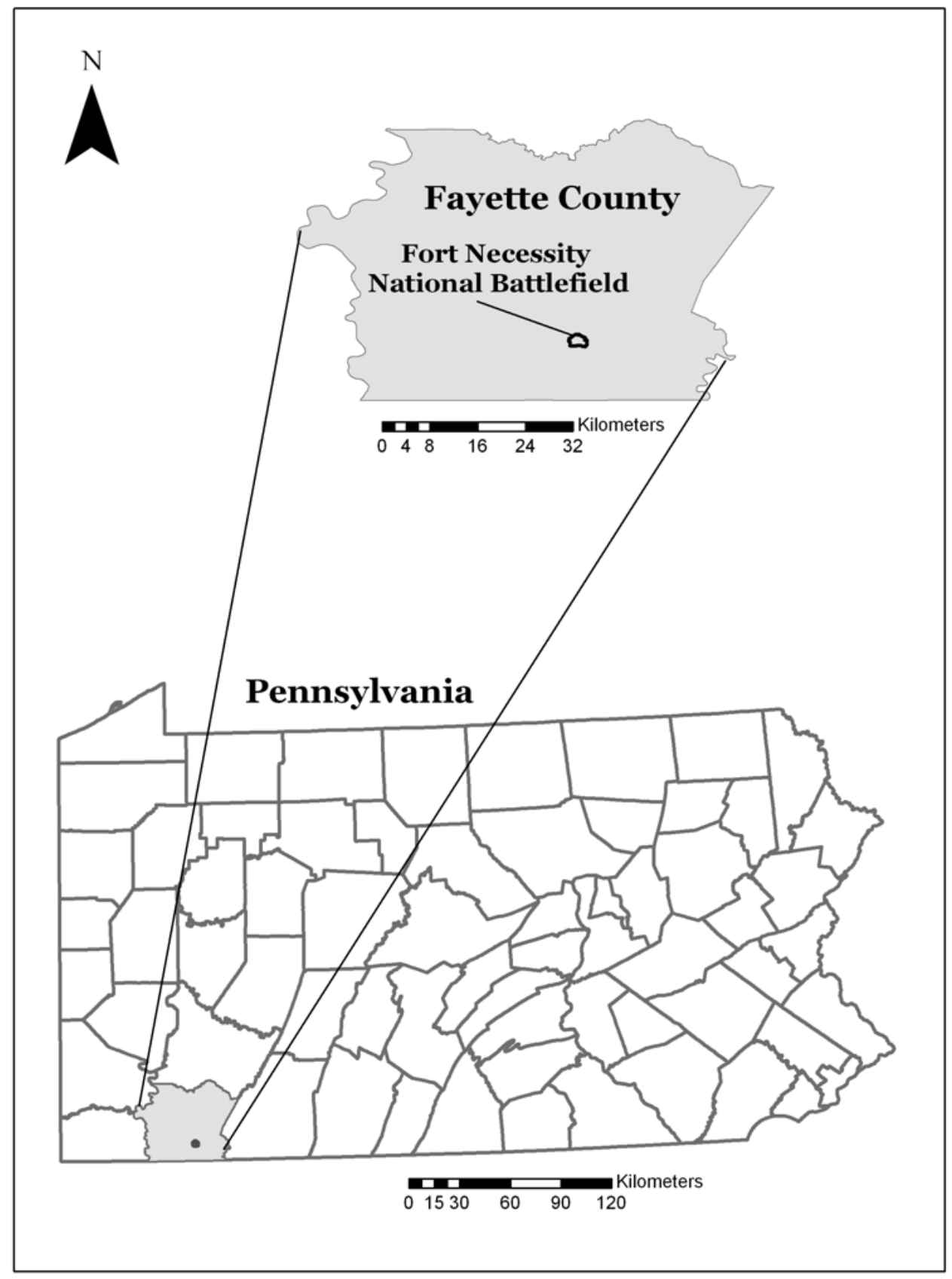

Figure 1. The Fort Necessity National Battlefield in Fayette County, Pennsylvania, USA. 


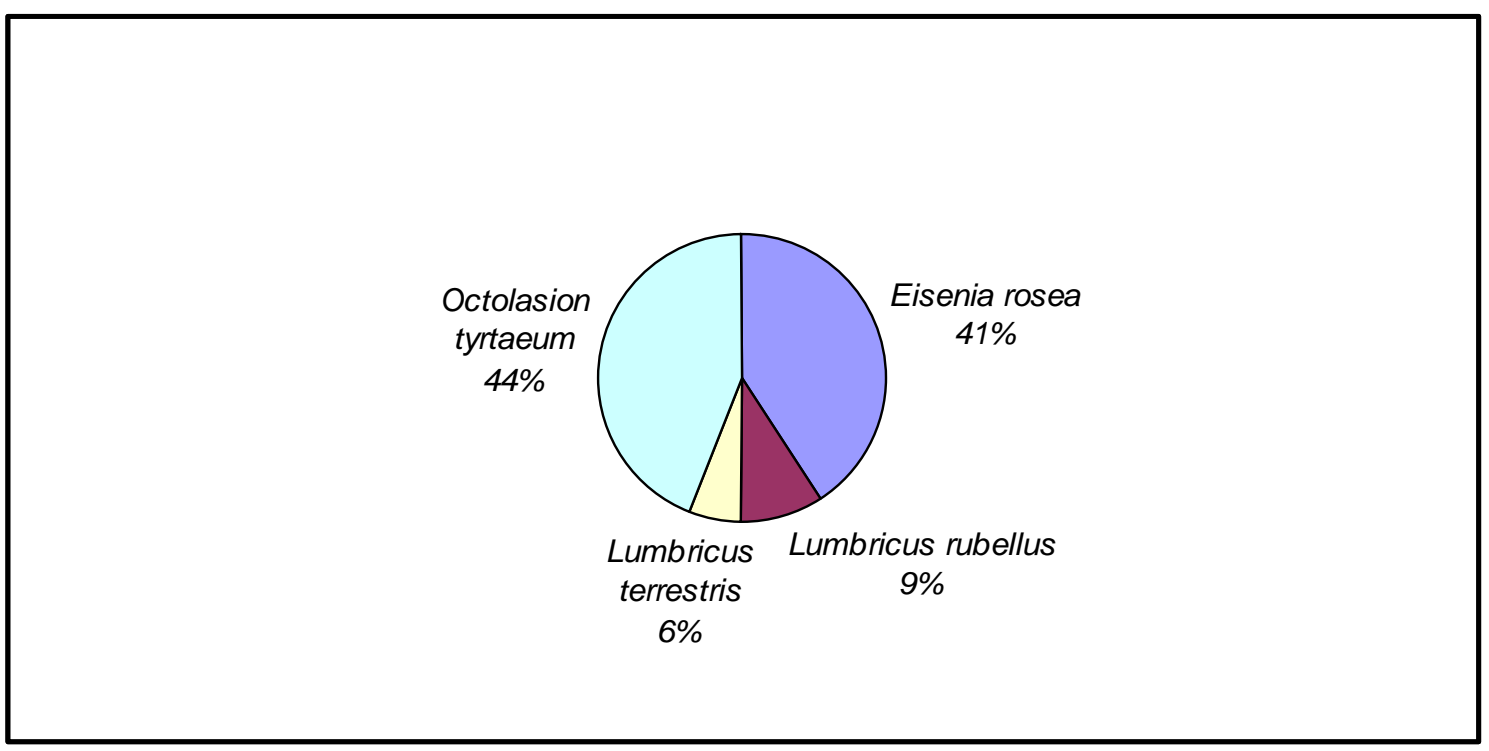

Figure 2. Percentage of each earthworm species collected from all plots at Fort Necessity National Battlefield in Fayette County, Pennsylvania, USA from $2004-2005$. N = 290 plots Total worms $=1,459$ individuals. 


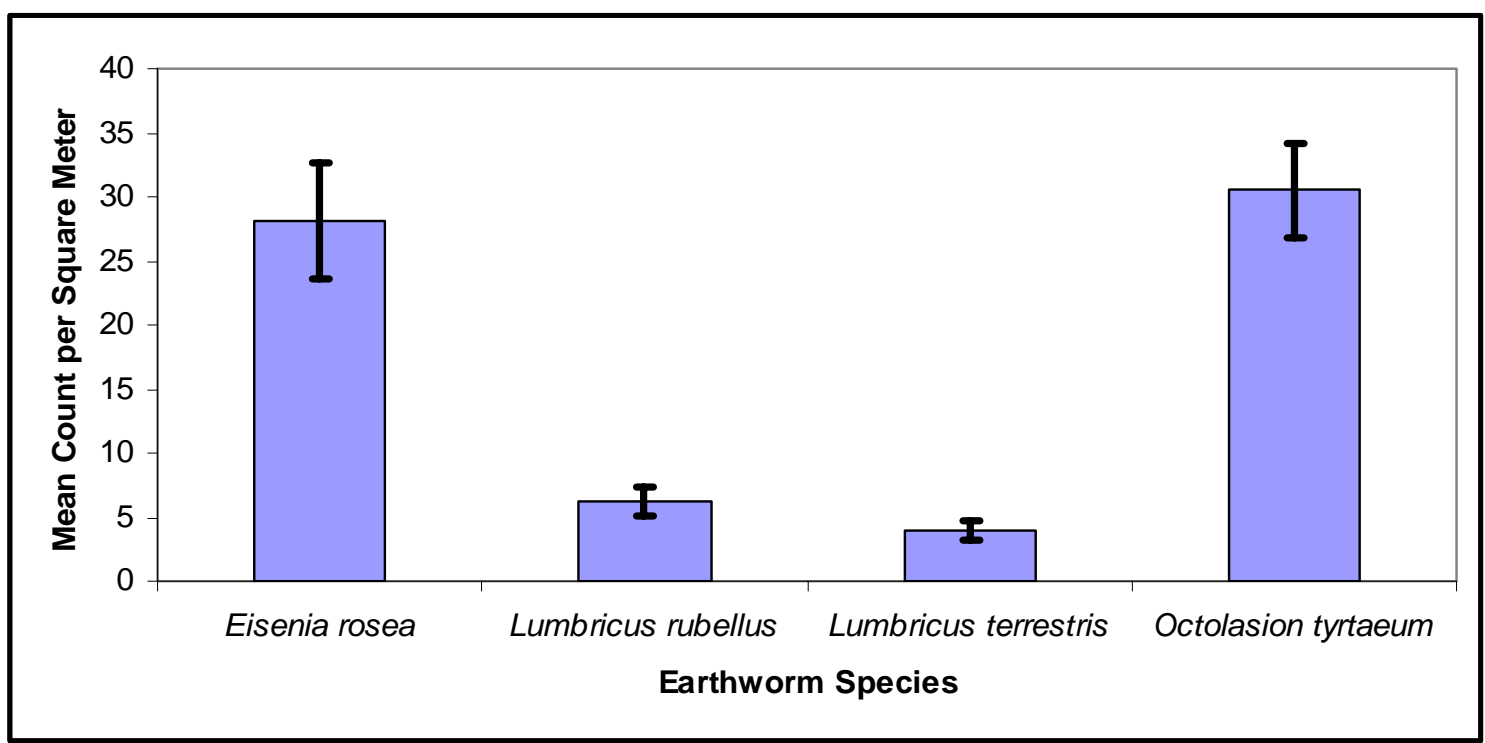

Figure 3. Mean density (earthworms per square meter) and standard error of each earthworm species pooled across all shrub/tree plots and open plots in all months at Fort Necessity National Battlefield in Fayette County, Pennsylvania, USA from 2004 - 2005. 


\title{
CHAPTER V
}

\section{CONCLUSIONS AND MANAGEMENT IMPLICATIONS FOR SMALL MAMMALS AND THE EARTHWORM COMMUNITY IN A DEGRADED ECOSYSTEM}

\begin{abstract}
$\underline{\text { Abstract }}$
The Fort Necessity National Battlefield (FONE) in Fayette County, Pennsylvania, USA has been invaded by an exotic bush honeysuckle called Morrow's honeysuckle (Lonicera morrowii) and the FONE has taken an aggressive stance to eradicate this and other species which threaten the ecological integrity of this historical site. Before such restoration actions are taken, the small mammal and earthworm communities were monitored to determine their relation to Morrow's honeysuckle at FONE in 2004 and 2005.
\end{abstract}

We trapped small mammals in areas dominated by Morrow's honeysuckle and we determined that prebaiting 1 and 2 days before the actual trapping period did not improve trapping success (Chapter 2). Traps that were prebaited did not capture more animals than traps that were not prebaited and therefore, we do not recommend using the added resources (i.e., time, money, personnel, and equipment) to incorporate prebaiting into trapping regimes. We also trapped and fluorescent powdertracked white-footed mice (Peromyscus leucopus) in old field and forested areas with about 13\% Morrow's honeysuckle encroachment to determine the microhabitat they selected (Chapter 3). We

This chapter is written in the style of The Proceedings of the West Virginia Academy of Sciences. 
found that the mice selected paths with low herbaceous cover; specifically, they preferred native herbaceous vegetation and avoided exotic vegetation. The mice also selected areas with greater shrub and tree cover. In 2005 they selected areas with greater protection from predators. Mice did not avoid Morrow's honeysuckle, however, they did avoid exotic herbaceous species. We recommend promoting native herbs, shrubs, and trees because all were important to the mice, and the native species are likely to provide the same, if not better resources for small mammals.

We determined shrubs and soil characteristics that were associated with 4 earthworm species (Chapter 4). Earthworm densities were largely dependent upon the shrub species. Two of these earthworm species are available to American Woodcock (Scolopax minor) and they are found under tulip poplar (Liriodendron tulipifera), Morrow's honeysuckle, and black locust (Robinia pseudoacacia). Moist soil, a low pH, and a low $\mathrm{C}: \mathrm{N}$ ratio were soil factors that predicted the presence of the desired earthworm species. These data will be useful for understanding the effects that worms may have on soil conditions and shrub species, as well as giving wildlife managers essential information to enhance earthworm populations for American woodcock.

\section{$\underline{\text { Introduction }}$}

\section{$\underline{\text { Restoration }}$}

The National Park Service takes an aggressive stance on the invasion of exotic species in America's parklands (National Park Service 1991). The National Park Service states that the forest will be managed to prevent damage by exotic species and the Park will manage species to help maintain health and diversity within the ecosystem, to ensure the continuation of rare, threatened, or endangered species, and to work toward 
reestablishing the vegetative conditions that existed during the historical period whenever possible (National Park Service 1991). Removing nonnative undesirable species may be the first major action for many land managers trying to reestablish a historical vegetative condition (Western Pennsylvania Conservancy 2003). By knowing how the existing biota functions in the degraded habitat and then documenting its change as the habitat is restored, future restoration in similar habitats becomes more predictable and achievable.

\section{$\underline{\text { Small Mammals }}$}

By dispersing seeds, consuming invertebrates, creating holes and tunnels underground, and themselves being a source of food to species in all vertebrate classes, small mammals can be an essential part of an ecosystem (Mazzotti et al. 1981; Longland and Clements 1995; Pearson et al. 2001). To capture small mammals, some studies recommend prebaiting traps (Chitty and Kempson 1949; MacCracken et al. 1985; Andersen 1994; Flowerdew et al. 2004) to improve the trapping success, however, studies conflict on whether or not prebaiting helps to capture more animals and is worth the added resources to a trapping regime (Bowman et al. 2001). No studies that tested prebaiting caught Peromyscus spp., the most common wild rodent across the United States (Merritt 1987). To determine the effectiveness of prebaiting, our objectives were to determine the amount of use the traps were getting during the prebaiting stage when the traps were secure in the "open" position and to compare the richness, diversity, and relative abundance of small mammals caught among the prebaited traps and the nonprebaited traps, as well as by year and month (Chapter 2).

Few studies on small mammals have taken place in areas with a species of honeysuckle on site (Anthony et al. 1981; McCay and Storm 1997), and we found no 
studies conducted among Morrow's honeysuckle. Morrow's honeysuckle, a bush native to Japan, reduces richness and cover of native herb communities (Rehder 1940; Batcher and Stiles 2004). We do not know the effects of exotic plants on small mammal communities (Pearson et al. 2001), yet current research suggests that exotic plant invasions have a high potential to alter small mammal ecology. As Morrow's honeysuckle out-competes and replaces native vegetation throughout the eastern United States (Batcher and Stiles 2004), natural habitats are lost for the wildlife existing there (Western Pennsylvania Conservancy 2003). We need to understand how the change in microhabitat may affect the small mammal community.

Microhabitat is defined as the physical and chemical variables in the environment that influence the time and energy used by an animal in its home range (Morris 1987). We trapped small mammals, coated them in fluorescent powder, and then released them so that they would make a visible trail wherever they traveled (Chapter 3). Our objectives were to determine the paths taken by the small mammals within woodland and old field areas with encroaching Morrow's honeysuckle and to understand their selection of paths based on the microhabitat they traversed (Chapter 3).

\section{Earthworms}

Earthworms provide many beneficial influences to soil processes such as increasing plant nutrient uptake, improving soil aeration, enhancing water infiltration, and speeding rates of litter decomposition (Hendrix and Bohlen 2002). In light of the beneficial effects, earthworms may also inflict detrimental effects to terrestrial ecosystems including: removing and burying the litter layer, which increases erosion and exposes root systems; dispersing weed seeds; increasing the leeching of nutrients to 
depths unavailable to plants; and decreasing soil carbon (Hendrix and Bohlen 2002). In most ecosystems, the main source of food for earthworms is litter from aboveground plant parts, but dead roots also are important (Curry 1998). Earthworms are selective when they ingest organic matter, meaning they prefer certain leaves over other plant leaves (James and Cunningham 1989; Lavelle et al. 1998). Our objectives for this study were to predict earthworm densities using shrub/tree species and open spaces, as well as soil characteristics (Chapter 4). The earthworm abundance holds additional interest because $80-90 \%$ of the American Woodcock diet is earthworms (Sepik et al. 1981). Wildlife managers can better manage for American Woodcock if the abundance and location of this bird's diet requirement, earthworms, is predictable (Chapter 4).

\section{$\underline{\text { Study Area and Methods }}$}

Our study site was located on a 390 ha historical park, Fort Necessity National Battlefield (FONE), located in Fayette County in southwestern Pennsylvania, USA (Figure 1). The climate is moderate continental with an average annual temperature of $9^{\circ}$ $\mathrm{C}$; mean winter temperature is $-3^{\circ} \mathrm{C}$ and mean summer temperature is $22^{\circ} \mathrm{C}$ (National Park Service 1991). Average annual precipitation is $119 \mathrm{~cm}$ (National Park Service 1991). Elevations within the park range from 535 - 710 m (National Park Service 1991).

On the upland sites, soils were moderately deep, moderate to well drained, and medium-textured soils underlain by acidic shale and sandstone bedrock (National Park Service 1991). Soils in the meadow region were deep, poor to moderately drained, medium-textured and were formed from acidic sandstone and shale sediments (Kopas 1973). The riparian and wet meadow areas are characterized by Philo silt loams (Kopas 
1973). Upland areas sampled were characterized by Brinkerton and Armagh silt loams, Cavode silt loams, and Gilpin channery silt loams (Kopas 1973).

Trapping for the two small mammal studies (Chapters 2 and 3) occurred on the upland areas where the current composition of vegetation has been extensively disturbed and invaded by non-native species (The Western Pennsylvania Conservancy, unpublished report). Morrow's honeysuckle covers most of the upland sites (National Park Service 1991); our small mammal grids were located in the most densely covered areas of the Morrow's honeysuckle invasion at FONE for one study (Chapter 2), and in 2 old field sites and in 2 forested sites for the second small mammal study (Chapter 3). In the second study, all 4 grids incorporated the Morrow's honeysuckle invasion at FONE with approximately 13\% Morrow's honeysuckle coverage on each grid. Earthworms were sampled throughout FONE on upland and wet meadow areas (Chapter 4).

Trapping for both small mammal trapping studies occurred in May - August of 2004 and 2005 (Chapters 2 and 3). For each small mammal study we established 4 separate $80 \times 120$ m grids with 150 trapping stations on each grid. When we captured an animal in a Sherman live trap (Small Folding Galvanized, $5 \times 6.4 \times 16.5 \mathrm{~cm}$ ), we recorded the following data: date and time of processing, species, total length, tail length, right ear length, right hindfoot length, mass, age (adult or juvenile), sex, reproductive condition (female: inactive, active, lactating, or pregnant; male: abdominal or testes length), and trap location (McDiarmid and Wilson 1996). We tagged every mouse and vole with a \#1005-1 monel ear tag (National Band and Tag Company, Newport, Kentucky 41072-0430), but we toe-clipped shrews. 
For the first study (Chapter 2), traps were randomly assigned to 1 of 3 prebaiting methods: one-third of the traps were prebaited 2 nights, one-third prebaited 1 night, and one-third had no prebaiting. We noted any evidence of animals entering the trap during the prebaiting period. Four nights of trapping immediately followed the prebaiting period. Animals with greater than 50 captures were used in our analyses.

For the second study (Chapter 3), we prepared animals for fluorescent powdertracking by placing each animal in a separate plastic bag with a small amount of red or green pigment, gently shook the bag to saturate the animal with the pigment (2-4 $\mu \mathrm{m}$-Radiant Color, Inc.), and then released it from a locked-open trap where it was captured (Lemen and Freeman 1985). The following night, we followed the animal's fluorescent trail with an ultraviolet 6 Watt Long Wave Lamp/Flashlight (Lab Safety Supply, Inc.-Lemen and Freeman 1985; Menzel et al. 2000). We marked the path every $1 \mathrm{~m}$ and where the trail turned until the trail was no longer visible (Jike et al. 1988; Menzel et al. 2000; McCay 2000). On the next day, we used line-transect sampling to measure the herbaceous vegetation, shrubs, trees, and amount of protection that occurred along the small mammal trails (Lemen and Freeman 1985; McShea and Gilles 1992; Menzel et al. 2000). We measured available microhabitat at 128 random trap stations, with methods similar to Dueser and Shugart (1978).

For the earthworm abundance study (Chapter 4) in May - Sept. of 2004 and 2005, we dug a total of 290 cylindrical pits measuring a diameter of $30.5 \mathrm{~cm}$ and a depth of 20 cm (Aplet 1990; James 1991), under 4 shrub/tree species (tulip poplar [Liriodendron tulipifera], black locust [Robinia pseudoacacia], southern arrowwood [Viburnum dentatum], and Morrow's honeysuckle), hereafter referred to as shrubs, and in open 
spaces. We used digging and hand-sorting to collect litter-dwelling and soil-dwelling earthworms (James and Seastedt 1986; Saetre 1998; Spurgeon et al. 1999; Kalisz and Powell 2000). To sample deep-burrowing worms, we poured a mustard and water solution into the dug pits to drive worms up to the surface (Lee 1985; Chan and Munro 2001). We also collected soil samples to analyze soil moisture and soil nutrients (i.e., $\mathrm{pH}$, available soil organic matter $[\mathrm{C}]$, nitrogen $[\mathrm{N}]$, phosphorus $[\mathrm{P}]$, and potassium $[\mathrm{K}]$ ).

\section{$\underline{\text { Results }}$}

\section{$\underline{\text { Small Mammals }}$}

For both small mammal studies combined (Chapters 2 and 3), we captured 596 white-footed mice (Peromyscus leucopus) in 24,009 trap nights. Additionally, we captured 232 meadow jumping mice (Zapus hudsonius), 124 meadow voles (Microtus pennsylvanicus), 89 masked shrews (Sorex cinereus), 83 shorttail shrews (Blarina brevicauda), 7 woodland jumping mice (Napaeozapus insignis), 7 eastern chipmunks (Tamias striatus), 6 deer mice (Peromyscus maniculatus), 2 red squirrels (Tamiasciurus hudsonicus), 2 southern bog lemmings (Synaptomys cooperi), and 1 southern flying squirrel (Glaucomys volans) (Table 1). None of the species captured are labeled "rare" on the Pennsylvania Natural Heritage Program's Rare Species List, though a few (meadow jumping mouse, southern bog lemming, and southern flying squirrel) were new species to the park (Yahner et al. 2004).

Traps that were prebaited did not capture more animals than traps that were not prebaited (Chapter 2). There were no differences in total species richness, diversity, or relative abundance for white-footed mice, meadow voles, meadow jumping mice, masked shrews, and shorttail shrews among prebaited and non-prebaited traps (Chapter 2). The 
total species richness in 2004 and 2005 was 42\%, 39\%, and 35\% lower in May than in June, July, or August respectively (Chapter 2). The relative abundance of meadow jumping mice in August was 81\%, 54\%, and 69\% greater than in May, June, or July respectively (Chapter 2). The relative abundances of shorttail shrews in May and June were lower than in July and August, but June did not differ from August (Chapter 2). Among the months, there were no differences in species diversity or the relative abundance of white-footed mice, meadow voles, or masked shrews (Chapter 2). The number of deaths in this study totaled 165 individuals (17\% of total captures died); shrews represented $63.0 \%$ of the mortalities (104 shrew deaths) (Chapter 2).

The microhabitat used by white-footed mice had less herbaceous cover than random areas measured (trap stations), but the mice selected paths with a greater coverage of shrub and tree cover (Chapter 3). In 2004, mice did not appear to select paths with a higher amount of protection from predators, but in 2005 , they traveled through areas with more protection (Chapter 3). The native plant species richness (number of plant species per $10 \mathrm{~m}$ ) was about $16 \%$ greater on trails, and the exotic species richness was about $42 \%$ greater at random trap stations (Chapter 3). Native herb diversity was about $63 \%$ greater on trails, whereas exotic herb diversity was about $38 \%$ greater at trap stations (Chapter 3). Trails had 67\% greater native herb evenness, whereas traps had about 26\% greater exotic herb evenness (Chapter 3). Combining native and exotic herbs into one group of total herbs, we found that the richness did not differ among traps and trails (Chapter 3). The diversity of total herbs was about $20 \%$ greater along trails than at random traps stations, and the evenness was about $41 \%$ greater on trails than trap stations (Chapter 3 ). The total percent coverage of native herbs was $63.8 \%$ of total 
herbaceous herb cover, and total native cover was $43.4 \%$ greater than the coverage of exotic herbs $(36.2 \%)$.

\section{$\underline{\text { Earthworms }}$}

We collected 4 species, all of which are exotic, introduced earthworms from Europe in the Family Lumbricidae (Olson 1980): Eisenia rosea (28.1 worms $/ \mathrm{m}^{2}$ on average), Lumbricus rubellus (1.1 worms $/ \mathrm{m}^{2}$ on average), Lumbricus terrestris (0.8 worms $/ \mathrm{m}^{2}$ on average), and Octolasion tyrtaeum (3.7 worms $/ \mathrm{m}^{2}$ on average). We collected a total of 1,459 earthworms with a biomass of 330.92 grams from 290 shrub plots and open plots.

For E. rosea, a soil dweller, the shrub species was the best factor to use in predicting its abundance, although the carbon to nitrogen $(\mathrm{C} / \mathrm{N})$ ratio ranked a close second at predicting E. rosea presence. For Lumbricus rubellus, a litter dweller, abundance was best predicted by the shrub species. For L. terrestris, a deep soil dweller, many factors effectively predicted its density including: the soil moisture, the $\mathrm{pH}$, the shrub species, and the $\mathrm{C} / \mathrm{N}$ ratio. For Octolasion tyrtaeum, another soil dweller, density was best estimated by using the $\mathrm{C} / \mathrm{N}$ ratio.

\section{Conclusions}

\section{$\underline{\text { Small Mammals }}$}

Any study that involves trapping small mammals is relatively costly in labor and the most efficient techniques need to be understood (Chitty and Kempson 1949). We do not recommend using prebaiting in attempts to increase trapping success because no difference in trapping success was recorded in prebaited traps compared to non-prebaited traps (Chapter 2). No correlation was found between the number of rodents captured and 
the effect of prebaiting (Chapter 2). Our goal was to perfect small mammal population estimation by using the most exact and economical methods, and we conclude that the least laborious and most effective means to trap small mammals is to abandon prebaiting altogether (Chapter 2). We found that researchers should be cautious trying to estimate the number of species inhabiting an area early in the summer, particularly in May, because we found that the species richness was greater later in the summer (Chapter 2). The meadow jumping mouse typically hibernates for eight months out of the year and may not have been active yet in May (Boonstra and Hoyle 1986). The small mammal community fluctuated through the summer months each year, but this did not affect the trapping success in prebaited traps (Chapter 2). The trapping in this study resulted in a high number of deaths, especially shrews. Shrew deaths in traps are common because they readily enter traps in the daytime, but without the presence of insects they die of starvation within a few hours of capture (Little and Gurnell 1989). We do not believe that these deaths influenced the effects of prebaiting because the animals were captured at least one time before they died.

The actual microhabitat characteristics used and the available vegetation measured at trap stations showed many differences (i.e., herbaceous cover, shrub cover, tree cover, native and exotic herb cover, the amount of protection) (Chapter 3). The white-footed mice favored more thinly vegetated areas, perhaps because they were responding to their predators that easily hunt in dense vegetation (i.e., raccoon [Procyon lotor], black rat snake [Elaphe obsoleta], feral cat [Felis catus], weasel [Mustela frenata], and coyote [Canis latrans]) rather than raptors that prefer to hunt in more open areas (Pearson et al. 2001). The mice could escape predation more easily in the sparsely 
vegetated areas (Barnum et al. 1992). Conversely, white-footed mice may be better able to forage on herb seeds, as well as insects in less dense vegetation (Pearson et al. 2001). Mice may have selected areas with shrub and tree cover both a food source and as structural cover (M'Closkey 1975; Williams 1999) and the Morrow's honeysuckle berries may have increased the use of the shrub strata (McShea and Francq 1984). This nonnative shrub produces an abundance of red berries in the summer and has invaded FONE up to a density of $72,000 \pm 4800$ plants/ha which totaled $248,587 \pm 13,825$ stems/ha (Love et al. 2005). The berries may not be a healthy substitution for the fruit of native shrubs, given that the honeysuckle berry is high in sugars, but relatively low in lipids and protein (Witmer 1996; Williams 1999). The complex branch structure of Morrow's honeysuckle may also encourage a slightly higher use than in other shrubs (M'Closkey 1975). Other studies agree that white-footed mice select areas with tree cover (Dueser and Shugart 1978; Kaufman et al. 1983; Mengak and Guynn 2003). Based on these results for the microhabitat characteristics measured, white-footed mice actively selected their paths within woodland and old field areas with encroaching Morrow's honeysuckle (Chapter 3).

If we had combined all herbs (native and exotic) into one group to determine the richness, diversity, and evenness, we would not have gained a true understanding of these indices. The richness would not have differed between trails and random trap stations, and although the diversity and evenness varied between trails and traps, the amount of variation was not as pronounced as our comparison of native and exotic plant groups (Chapter 3). Fort Necessity has a relatively large percentage of exotic herb species, $36.2 \%$, which may pose problems in the future if many of these species are invasive in 
nature. Dominant native herbs at FONE included: common cinquefoil (Potentilla simplex), wrinkleleaf goldenrod (Solidago rugosum), deertongue (Dichanthelium clandestinum), calico aster (Symphyotrichum lateriflorum), and wild basil (Clinopodium vulgare). Dominant exotic herbs included: sweet vernal grass (Anthoxanthum odoratum), common yarrow (Achillea millifolium), meadow hawkweed (Hieracium caespitosum), crown vetch (Coronilla varia), and rough bluegrass (Poa trivialis). Whitefooted mice avoided exotic herbaceous cover when they traveled and with less desirable species invading their habitat, their preferred pathways may become significantly reduced if measures are not taken to control these exotic herbs.

\section{Earthworms}

Given that the earthworm species found at FONE each possess unique behavioral characteristics (i.e., litter dwellers, soil dwellers, or deep-soil dwellers), the soil factors that were predictive of their presence were also unique for each species. A useful equation for predicting the density $(Y)$ of $E$. rosea per square meter is: $Y=1.8274-$ $(2.3722 \times(\mathrm{C} / \mathrm{N}))$, where $\mathrm{C} / \mathrm{N}$ is the carbon to nitrogen ratio at any given sampling point. The density of E. rosea was tied strongly to tulip poplar, and to a lesser degree, black locust and southern arrowwood. Lumbricus rubellus also was strongly tied to tulip poplar and to a lesser degree black locust and Morrow's honeysuckle. The factors that effectively predicted the density of $L$. terrestris varied among soil moisture (SM), $\mathrm{pH}$, shrub species (SP), and $\mathrm{C} / \mathrm{N}$ and indicate that these factors combined may best predict $L$. terrestris densities. The following equation best estimated the number of $L$. terrestris per square meter $(Y)$ that were present $Y=2.9044-(0.0596 \times \mathrm{SM})-(1.1602 \times \mathrm{pH})-$ $(1.7141 \times \mathrm{C} / \mathrm{N})$. In combination with using the model, we note that underneath tulip 
poplar and Morrow's honeysuckle we found the greatest abundances of L. terrestris.

Octolasion tyrtaeum density $(Y)$ can best be predicted by using the equation, $Y=0.0631+$ $(2.8298 \times(\mathrm{C} / \mathrm{N}))$.

\section{Management Implications}

\section{$\underline{\text { Small Mammals }}$}

Wildlife managers need to know the fastest and most cost-efficient way to capture the most individuals in a given area. We had good trapping success in the prebaiting study, in that by the fourth trapping night in all months, most animals (61\%) were recaptures. We suggest using 4 trap nights without prebaiting to yield sufficient and reliable density estimates, and that adding prebaiting would only affix a greater cost to the project (Chapter 2). To reduce the number of deaths in traps, especially the large number of shrew deaths, we suggest closing the traps when they are checked at 0600 $1000 \mathrm{hrs}$ and then resetting the traps each day at $1700-2000 \mathrm{hrs}$; however this trapping regime would use more resources (e.g., time, money, equipment, and technical assistance) to visit the traps twice each day instead of one time as in our study (Howard 1959).

Given the affinity towards areas with less dense herbaceous vegetation and towards native rather than exotic herbs, we recommend applying an herbicide or burning the site to decrease the overall herbaceous layer, manage for native vegetation, and decrease exotic vegetation. Treatment with a glyphosate herbicide has been shown to have little or no effect to recruitment of mice and vole young (Sullivan 1990). Additionally, native plant species may have more nutritious fruit or seeds for small mammals (Williams 1999), and with an increased herbaceous layer and high-quality food 
supply, small mammal populations are expected to increase or remain stable. Mowing is not a management option that we recommend because more exotic herbs were growing in the old field areas after mowing in 2004 (personal observation). Mowing also causes a disruption in the social structure of many small mammals by causing individuals to abandon home ranges and territories (Edge et al. 1995). Mowing should occur at the beginning of the growing season (i.e., before May) prior to summer months of greater small mammal activity (Chapter 2). Greater cover and food (i.e., seeds, fruits, invertebrates) would result if mowing occurred prior to the beginning of the growing season, rather than during the growing season (i.e., May, June, July) (Love et al. 2005). However, mowing in conjunction with spot herbicide treatment and planting of native species may be successful.

White-footed mice used areas with shrub and tree cover extensively in both 2004 and 2005 (Chapter 3). For this reason, we recommend promoting a native shrub and tree stratum because mice tend to be food-limited (Ortega et al. 2004) and native shrubs and trees typically provide higher-quality fruits than exotics, notably honeysuckle bushes and vines. (Williams 1999). Many native shrubs that currently exist at FONE (i.e., Southern arrowwood [Viburnum dentatum], common serviceberry [Amelanchier arborea], waxyfruit hawthorne [Crataegus pruinosa], and deerberry [Vaccinium stamineum]) may sufficiently supply adequate resources to small mammals, rather than exotic shrubs occurring at FONE (i.e., Morrow's honeysuckle, multiflora rose [Rosa multiflora], and Japanese barberry [Berberis thunbergii]). The native shrubs can provide the structural complexity that white-footed mice select (M'Closkey 1975), as well as nutritious, high protein fruits (Witmer 1996; Williams 1999). Promoting shrubs and trees may also favor 
the shrew populations because shrew abundance and diversity are positively related to ground moisture (McCay and Storm 1997); shrub cover would help retain moisture. Shrews have been shown to increase in density and extend their breeding season with an abundance of littoral foods (i.e., earthworms and gastropods in the spring, beetle and fly larvae in the fall) (McCay and Storm 1997), and therefore, sparse shrubs and trees would allow a diversity of herbs and invertebrates in the open spaces.

\section{Earthworms}

We developed these predictive equations to estimate the densities of earthworm species, so that we gain a better understanding of plant and soil characteristics that are associated with earthworm species. For the earthworm species at FONE, tulip poplar or black locust supported the highest average density rather than Morrow's honeysuckle. Evidence in this study shows that exotic earthworms are not discouraged from existing in soil underneath exotic plant species, namely Morrow's honeysuckle. Earthworms are generally thought to provide beneficial changes to soil structure, nutrient dynamics, and plant growth; however, exotic earthworms may have undesirable effects on other organisms and soil processes in their new habitats (Hendrix and Bohlen 2002). Bohlen et al. (2004) warn that invading exotic earthworms can rapidly decrease the abundance and diversity of native tree seedlings. At FONE, it remains unknown as to whether these exotic earthworms will hinder or enhance native shrub and tree growth after the exotic Morrow's honeysuckle is removed for the restoration at FONE.

The earthworm species that occur at shallow enough depths for the $59-77 \mathrm{~mm}$ American woodcock beak include L. rubellus, L. terrestris, and E. rosea (Keppi and Whiting 1994). These earthworm species were found in far greater abundances under 
tulip poplar than any other shrub (Chapter 4). Morrow's honeysuckle and black locust also had high numbers of these earthworm species (Chapter 4). Removal of Morrow's honeysuckle at FONE may decrease the number of earthworms, and thus the food supply of American woodcock; however, the desired earthworm species are also found under tulip poplar, and under black locust to a lesser amount (Chapter 4). An important consideration is that the Morrow's honeysuckle shrubs used in this study were single shrubs that were greater than $2 \mathrm{~m}$ away from other shrubs (Chapter 4). Therefore, the dense clumps of honeysuckle, which characterize much of the upland areas at FONE, are not indicative of ideal earthworm habitat. Removal of the dense thickets of Morrow's honeysuckle may not reduce the earthworm population. Southern arrowwood, a native shrub, was associated with lower abundances of the 3 of 4 exotic earthworms and should be considered in revegetation plans for the site.

If Morrow's honeysuckle is removed from FONE, reforestation after the removal has a great potential to increase the number of earthworms, however, conifers are not recommended for the reforestation management option. The palatability of coniferous tree species (being highly acidic) results in few earthworms living under conifers (Dessecker and McGauley 2001). Based on limited exploratory samples in forested areas and under tulip poplar within FONE, earthworms will likely disperse and flourish among the young hardwoods. American woodcock will likely use the young hardwood stands though they are less likely to use the area as the hardwoods mature and the understory becomes sparse (Dessecker and McGauley 2001). 


\section{Future Research}

\section{$\underline{\text { Small Mammals }}$}

Prebaiting could be monitored more intensely during the prebaiting period to determine if animals visit more than one trap. If small mammals were marked in the prebaiting period, then their trap fidelity would be known. We suggest that a future study could mark each prebaited trap with a unique color of fluorescent powder and then monitor whether the unique colors were found in other traps; this would determine the extent of loyalty to one trap location. Fluorescent colors come in violet, white, green, yellow, red, orange, blue, invisible blue, invisible orange, invisible red, invisible green and invisible yellow from Shannon Luminous Materials, Inc.C and in Columbia blue, UV-blue, sky blue, and ice blue from Dayglo@. Powders also can be mixed to create more colors. Radiant Color $(\mathrm{C}$ where we purchased fluorescent powder from no longer exists.

With such an extreme disparity between the selection of native herbs and the avoidance of exotic herbs, we suggest that researchers further examine the cause for the path choice. We pose the questions: 1) What do native herbs provide for the animals that exotic herbs do not? and; 2) Why did the white-footed mice avoid exotic herbs? Areas dominated by exotic plants have altered vegetative structure and resource availability. Changes in vegetative structure and resource availability brought about by exotic plants have the potential to decrease the carrying capacity of native flora and fauna (Scheiman et al. 2003). More research is needed to understand the consequences of these relatively rapid vegetative changes in small mammal habitat. 


\section{$\underline{\text { Earthworms }}$}

Ongoing documentation and monitoring through the future restoration process is needed to determine the earthworm species that will remain, disperse, or move into the newly disturbed, Morrow's honeysuckle-free site. Singing song surveys at FONE in 2004 and 2005 revealed a relatively large number (23 males in 2004 and 31 males in 2005) of American woodcock located in the study area (Love et al. unpublished). With this population at FONE, their diet may be better understood by observing the woodcock during their feeding activities to determine exactly which species of earthworms the birds are consuming. We do not recommend sacrificing birds to conduct stomach content analyses because their numbers have been declining in the past 4 decades (Kelley 2001). Probe holes in the ground can be located to determine where their feeding is located. Additionally, digging and hand-sorting worms could be conducted where the probe holes are found to determine the probable species of worms that the woodcock are ingesting.

\section{$\underline{\text { Literature Cited }}$}

Barnum, S. A., C. J. Manville, J. R. Tester, and W. J. Carmen. 1992. Path selection by Peromyscus leucopus in the presence and absence of vegetative cover. Journal of Mammalogy 73:797-801.

Batcher, M. S. and Stiles, S. A. Element Stewardship Abstract for the Bush Honeysuckles, The Nature Conservancy. http://ncweeds.ucdavis.edu/esadocs/documnts/loni sp.html. Accessed February $10,2004$. 
Bohlen P. J., D. M. Pelletier, P. M. Groffman, T. J. Fahey, and M. C. Fisk. 2004. Influence of earthworm invasion on redistribution and retention of soil carbon and nitrogen in northern temperate forests. Ecosystems 7:13-27.

Boonstra, R. and J. A. Hoyle. 1986. Rarity and coexistence of a small hibernator, Zapus $\underline{\text { hudsonius, }}$ with fluctuating populations of Microtus pennsylvanicus in the grasslands of southern Ontario. Journal of Animal Ecology 55:773-784.

Chan, K. and K, Munro. 2001. Evaluating mustard extracts for earthworm sampling. Pedobiologia 45:272-278.

Chitty, D. and D. A. Kempson. 1949. Prebaiting small mammals and a new trap design of live trap. Ecology 30:536-542.

Curry, J. P. 1998. Factors affecting earthworm abundance in soils. Pages 37-64 in Edwards, C. A. 1998. Earthworm Ecology. St. Lucie Press. Boca Raton, FL.

Dessecker, D. R. and D. G. McGauley. 2001. Importance of early successional habitat to ruffed grouse and American Woodcock. Wildlife Society Bulletin 29:456-465.

Dueser R. D. and H. H. Shugart, Jr. 1978. Microhabitats in a forest-floor small mammal fauna. Ecology 59:89-98.

Edge, W. D., J. O. Wolff, and R. L. Carey. 1995. Density-dependent responses of graytailed voles to mowing. Journal of Wildlife Management 59:245-251.

Hendrix, P. F. and P. J. Bohlen. 2002. Exotic earthworm invasions in North America: ecological and policy implications. Bioscience 52:801-811.

Howard, W. E. 1959. How to overcome bait shyness in rodents. Pest Control 27:913. 
James, S. W. 1991. Soil, nitrogen, phosphorus, and organic matter processing by earthworms in tallgrass prairie. Ecology 72:2101-2109.

James, S. W. and M. R. Cunningham. 1989. Feeding ecology of some earthworms in Kansas Tallgrass Prairie. American Midland Naturalist 121:78-83.

James, S. W. and T. R. Seastedt. 1986. Nitrogen mineralization by native and introduced earthworms: effects on bluestem growth. Ecology 67:1094-1097.

Jike, L., G. O. Batzli, L. L. Getz. 1988. Home ranges of prairie voles as determined by radiotracking and by powdertracking. Journal of Mammalogy 69:183-186.

Kalisz, P. J. and J. E. Powell 2000. Invertebrate macrofauna in soils under old growth and minimally disturbed second growth forests of the Appalachian Mountains of Kentucky. American Midland Naturalist 144:297-307.

Kaufman, D. W., S. K. Peterson, R. Fristik, and G. A. Kaufman. 1982. Effect of microhabitat features on habitat use by Peromyscus leucopus. The American Midland Naturalist 110:177-185.

Keppie, D. M. and R. M. Whiting, Jr. 1994. American Woodcock (Scolopax minor). In Poole, A. and F. Gill, eds. The Birds of North America, No. 100. The American Ornithologists' Union. Philadelphia: The Academy of Natural Sciences; Washington, D.C.

Kelley, J. R. 2001. American woodcock population status, 2001. U.S. Fish and Wildlife Service, Laurel, MD.

Kopas, F. A. 1973. Soil survey of Fayette County, Pennsylvania. United States Department of Agriculture/Soil Conservation Service, Washington, D.C. 
Lavelle, P., B. Pashanasi, F. Charpentier, C. Gilot, J. Rossi, L. Derouard, J. Andre, J. Ponge, and N. Bernier. 1998. Large-scale effects of earthworms on soil organic matter and nutrient dynamics. Pages 103-122 in Edwards, C. A. 1998. Earthworm ecology. St. Lucie Press. Boca Raton, FL.

Lee, K. E. 1985. Earthworms, their ecology and relationships with soils and land use. Academic Press, Orlando, FL.

Lemen C. A. and P. W. Freeman. 1985. Tracking mammals with fluorescent pigments: a new technique. Journal of Mammalogy 66:134-136.

Little, J, and J. Gurnell. 1989. Shrew capture and rodent field studies. Journal of Zoology 218:329-331.

Longland, W. S. and C. Clements. 1995. Use of fluorescent pigments in studies of seed caching by rodents. Journal of Mammalogy 76:1260-1266.

Love, J. P., J. A. Edalgo, and J. T. Anderson. 2005. Management plan for a degraded meadow with Morrow’s honeysuckle. Fort Necessity National Battlefield, Fayette County, PA. Unpublished report.

MacCracken, J. G., D. W. Uresk, and R. M. Hansen. 1985. Rodent-vegetation relationships in southwestern Montana. Northwest Science 59:272-278.

Mazzotti, F. J., W. Ostrenko, and A. T. Smith. 1981. Effects of the exotic plants

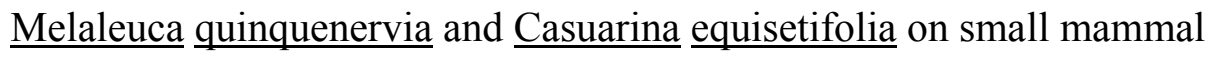
populations in the eastern Florida Everglades. Florida Scientist 44:65-71.

McCay, T. S. 2000. Use of woody debris by cotton mice (eromyscus gossypinus) in a southeastern pine forest. Journal of Mammalogy 81:527-535. 
McCay, T. S. and G. L. Storm. 1997. Masked shrew ( and prey selection in an irrigated forest. American Midland Naturalist 138:268275.

McDiarmid, R. W. and D. E. Wilson. 1996. Data standards. Pages 56-60 in D. E. Wilson, F. R. Cole, J. D. Nichols, R. Rudran, and M. S. Foster, editors. 1996. Measuring and monitoring biological diversity. Smithsonian Institution Press, Washington, D.C.

M’Closkey, R. T. 1975. Habitat dimensions of white-footed mice, Peromyscus leucopus. American Midland Naturalist 93:158-167.

McShea, W. J. and A. B. Gilles. 1992. A comparison of traps and fluorescent powder to describe foraging for mast by Peromyscus leucopus. Journal of Mammalogy $73: 218-222$.

McShea, W. J. and E. N. Francq. 1984. Microhabitat selection by Peromyscus leucopus. Journal of Mammalogy 65:675-678.

Mengak, M. T. and D. C. Guynn Jr. 2003. Small mammal microhabitat on young loblolly pine regeneration areas. Forest Ecology and Management 173:309-317.

Menzel, M. A., T. C. Carter, L. R. Jablonowski, and J. Laerm. 2000. The effect of time of release on microhabitat use by the white-footed mouse. Acta Theriologica 45:167-173.

Merritt, J. F. 1987. Mammals of Pennsylvania. University of Pittsburgh Press, Pittsburgh, PA.

Morris, D. W. 1987. Ecological scale and habitat use. Ecology 68:362-369. 
National Park Service. 1991. General Management Plan/Development Concept Plan/Interpretive Prospectus: Fort Necessity National Battlefield. U. S. Department of the Interior Prepared by the Denver Service Center, Denver, $\mathrm{CO}$.

Ortega, Y. K., D. E. Pearson, and K. S. McKelvey. 2004. Effects of biological control agents and exotic plant invasions on deer mouse populations. Ecological Applications 14:241-253.

Pearson, D. E., Y. K. Ortega, K. S. McKelvey, and L. F. Ruggiero. 2001. Small mammal communities and habitat selection in northern Rocky Mountain bunchgrass: implications for exotic plant invasions. Northwest Science 75:107117.

Saetre, P. 1998. Decomposition, microbial community structure, and earthworm effects along a birch-spruce soil gradient. Ecology 79:834-846.

Sepik, G. F. and R. B. Owen, Jr., and M. W. Coulter. 1981. A landowner's guide to woodcock management in the Northeast. Maine Agricultural Experiment Station. Report no. 253.

Scheiman, D. M., E. K. Bollinger, and D. H. Johnson. 2003. Effects of leafy spurge infestation on grassland birds. Journal of Wildlife Management 67:115-121.

Spurgeon, D. J. and S. P. Hopkin. 1999. Seasonal variation in the abundance, biomass and biodiversity of earthworms in soils contaminated with metal emissions from a primary smelting works. Journal of Applied Ecology 36:173-183.

Sullivan, T. P. 1990. Influence of forest herbicide on deer mouse and Oregon vole Population dynamics. Journal of Wildlife Management 54:566-576. 
Western Pennsylvania Conservancy. 2003. Plant community mapping and surveys for species of special concern at Allegheny Portage Railroad National Historic Site, Johnstown Flood National Memorial, Fort Necessity National Battlefield, and Friendship Hill National Historic Site, PA.

Williams, C. E. 1999. Fruits of alien shrubs and deer mice: a test of the persistent fruit defense hypothesis. Journal of the Pennsylvania Academy of Science 73:33-37.

Witmer, M. C. 1996. Consequences of an alien shrub on the plumage coloration and ecology of cedar waxwings. Auk 113:735-743.

Yahner, R. H., B. D. Ross, and J. E. Kubel. 2004. Comprehensive inventory of birds and mammals at Fort Necessity National Battlefield and Friendship Hill National Historic Site. U.S. Dept. of the Interior, National Park Service, Northeast Region, Philadelphia, PA. Technical Report NPS/NERCHAL/NRTR-04/093. 
Table 1. We captured 11 species of small mammals at Fort Necessity National Battlefield in Fayette County, Pennsylvania, USA from 2004 - 2005 using Sherman live traps. The grids Nursery, Fort, Zoo, and Upland were trapped for Chapter 2 and were located in the densest Morrow's honeysuckle areas. The grids included in Forest and Field were trapped for Chapter 3 and included about 13\% Morrow's honeysuckle invasion.

\begin{tabular}{|c|c|c|c|c|c|c|c|}
\hline \multirow[b]{2}{*}{ Species } & \multicolumn{2}{|c|}{ Treatment } & \multicolumn{2}{|c|}{ Control } & \multirow[b]{2}{*}{ Forest } & \multirow[b]{2}{*}{ Field } & \multirow[b]{2}{*}{ Total } \\
\hline & Fort & Nursery & Zoo & Upland & & & \\
\hline $\begin{array}{l}\text { White-footed mouse } \\
\text { Peromyscus leucopus }\end{array}$ & 166 & 154 & 74 & 68 & 85 & 49 & 596 \\
\hline $\begin{array}{l}\text { Deer mouse } \\
\text { Peromyscus maniculatus }\end{array}$ & 0 & 1 & 0 & 0 & 3 & 2 & 6 \\
\hline $\begin{array}{l}\text { Meadow vole } \\
\text { Microtus pennsylvanicus }\end{array}$ & 0 & 21 & 26 & 42 & 0 & 35 & 124 \\
\hline $\begin{array}{l}\text { Southern bog lemming } \\
\text { Synaptomys cooperi }\end{array}$ & 0 & 0 & 2 & 0 & 0 & 0 & 2 \\
\hline $\begin{array}{l}\text { Meadow jumping mouse } \\
\text { Zapus hudsonius }\end{array}$ & 38 & 43 & 97 & 43 & 2 & 9 & 232 \\
\hline $\begin{array}{l}\text { Woodland jumping mouse } \\
\text { Napaeozapus insignis }\end{array}$ & 0 & 0 & 0 & 0 & 5 & 2 & 7 \\
\hline $\begin{array}{l}\text { Shorttail shrew } \\
\text { Blarina brevicauda }\end{array}$ & 14 & 25 & 18 & 21 & 2 & 3 & 83 \\
\hline $\begin{array}{l}\text { Masked shrew } \\
\text { Sorex cinereus }\end{array}$ & 13 & 21 & 43 & 9 & 2 & 1 & 89 \\
\hline $\begin{array}{l}\text { Southern flying squirrel } \\
\text { Glaucomys volans }\end{array}$ & 0 & 0 & 0 & 0 & 1 & 0 & 1 \\
\hline $\begin{array}{l}\text { Eastern chipmunk } \\
\text { Tamias striatus }\end{array}$ & 0 & 0 & 6 & 1 & 0 & 0 & 7 \\
\hline $\begin{array}{l}\text { Red squirrel } \\
\text { Tamiasciurus hudsonicus }\end{array}$ & 1 & 0 & 0 & 0 & 0 & 0 & 1 \\
\hline Total & 232 & 265 & 266 & 184 & 100 & 101 & 1148 \\
\hline
\end{tabular}


Figure 1. The Fort Necessity National Battlefield in Fayette County, Pennsylvania, USA.

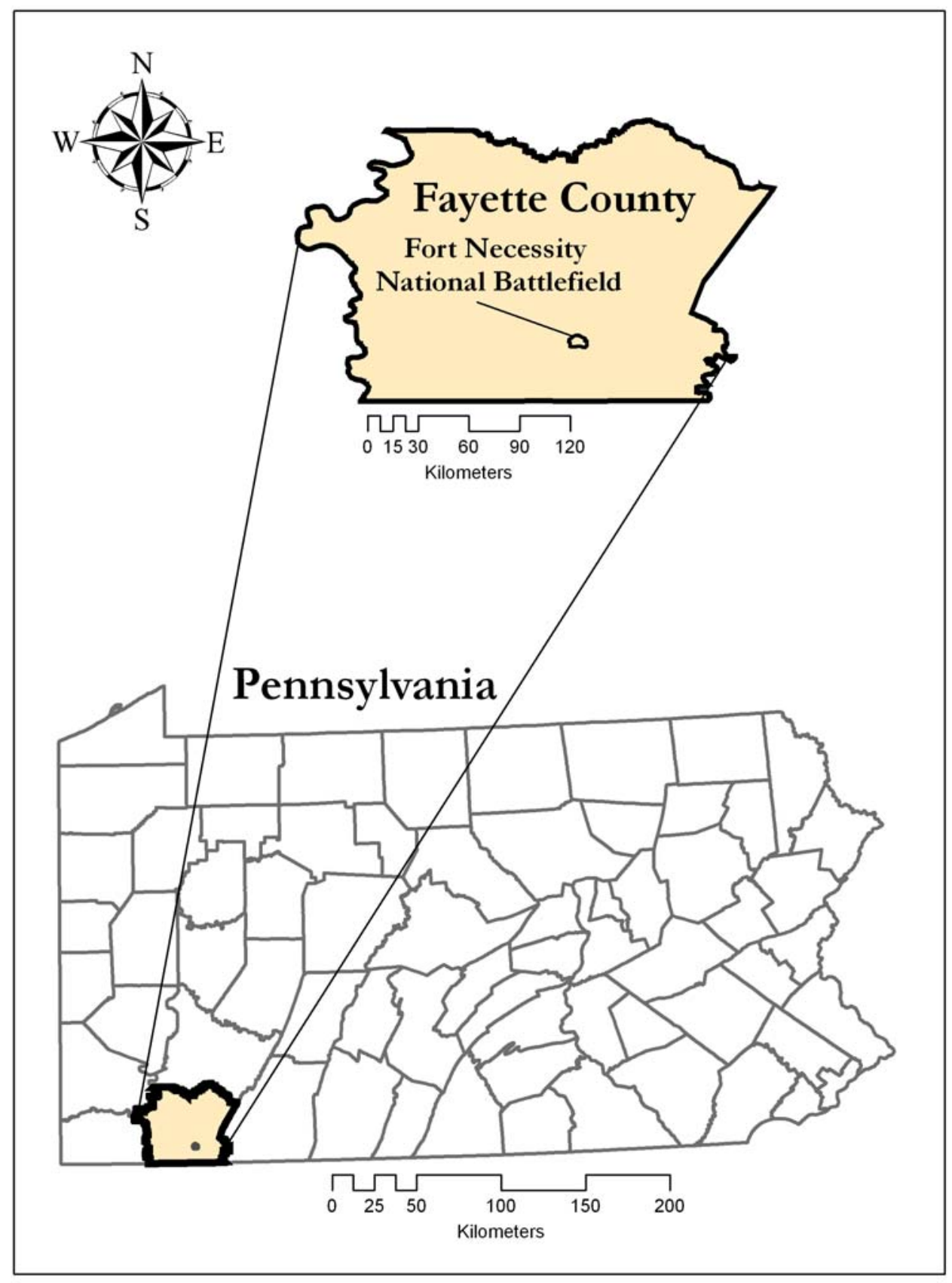


Appendix IIa. Species richness, Simpson's index of diversity, and relative abundance (total individuals captured per 100 trap nights) based on captures during 1 night of trapping for 3 prebaiting methods on 4 trapping grids dominated by Morrow's honeysuckle (Lonicera morrowii) at Fort Necessity National Battlefield in Fayette County, Pennsylvania, USA in 2004 and 2005.

\begin{tabular}{|c|c|c|c|c|c|c|c|c|c|}
\hline \multirow[b]{4}{*}{ Dependent Variable ${ }^{\mathrm{a}}$} & & & & \multirow{2}{*}{\multicolumn{6}{|c|}{$\begin{array}{l}\text { No. Nights } \\
\text { Prebaited }\end{array}$}} \\
\hline & & & & & & & & & \\
\hline & \multicolumn{3}{|c|}{ ANOVA Results } & \multicolumn{2}{|c|}{2 Nights ${ }^{\mathrm{b}}$} & \multicolumn{2}{|c|}{1 Night $^{b}$} & \multicolumn{2}{|c|}{0 Nights $^{\mathrm{b}}$} \\
\hline & $F$-valu & e d.f. & $P$-value & $\overline{\mathrm{x}}$ & SE & $\overline{\mathrm{x}}$ & SE & $\overline{\mathrm{x}}$ & SE \\
\hline Species Richness & 0.11 & 2,17 & 0.8949 & $1.040 \mathrm{~A}$ & 0.178 & $1.127 \mathrm{~A}$ & 0.186 & $0.997 \mathrm{~A}$ & 0.227 \\
\hline Simpson's Index of Diversity & 0.37 & 2,17 & 0.6982 & $0.620 \mathrm{~A}$ & 0.126 & $0.698 \mathrm{~A}$ & 0.069 & $0.562 \mathrm{~A}$ & 0.133 \\
\hline \multicolumn{10}{|l|}{ Relative Abundance $^{c}$} \\
\hline White-footed mouse & 0.47 & 2,17 & 0.6354 & $4.630 \mathrm{~A}$ & 1.463 & $6.322 \mathrm{~A}$ & 2.272 & $3.992 \mathrm{~A}$ & 1.414 \\
\hline Meadow Jumping mouse & 0.55 & 2,17 & 0.5873 & $3.145 \mathrm{~A}$ & 1.312 & $1.912 \mathrm{~A}$ & 0.779 & $1.880 \mathrm{~A}$ & 0.707 \\
\hline Meadow Vole & 0.30 & 2,17 & 0.7427 & $0.993 \mathrm{~A}$ & 0.311 & $1.387 \mathrm{~A}$ & 0.488 & $0.897 \mathrm{~A}$ & 0.575 \\
\hline Masked Shrew & 0.07 & 2,17 & 0.9285 & $0.755 \mathrm{~A}$ & 0.555 & $0.663 \mathrm{~A}$ & 0.302 & $0.897 \mathrm{~A}$ & 0.396 \\
\hline Shorttail Shrew & 0.72 & 2,17 & 0.5010 & $1.820 \mathrm{~A}$ & 1.050 & $0.607 \mathrm{~A}$ & 0.226 & $1.260 \mathrm{~A}$ & 0.612 \\
\hline \multicolumn{10}{|c|}{${ }^{\mathrm{a}}$ Values were calculated from untransformed dependent variables. } \\
\hline \multicolumn{10}{|c|}{${ }^{\mathrm{b}}$ The same letter following means in a row indicates no difference $(P>0.05)$ according } \\
\hline \multicolumn{10}{|c|}{ to Duncan's Multiple Range Test. } \\
\hline \multicolumn{10}{|c|}{${ }^{\mathrm{c}}$ The total captures for small mammals including recaptures are as follows: white-footed } \\
\hline \multicolumn{10}{|c|}{ mice ( $n=124$ individuals), meadow jumping mice $(n=65$ individuals), meadow voles ( $n$} \\
\hline \multicolumn{10}{|c|}{$=27$ individuals), masked shrews $(n=20$ individuals $)$, shorttail shrews $(n=28$} \\
\hline
\end{tabular}


Appendix IIb. Average coverage (\%) of shrub species that occurred on the 4 small mammal grids used to test the effects of prebaiting at Fort Necessity National Battlefield in Fayette County, Pennsylvania, USA from 2004-2005.

\begin{tabular}{|c|c|c|c|c|}
\hline \multirow[b]{2}{*}{ Shrub Species $^{\mathrm{a}}$} & \multicolumn{2}{|r|}{ Small Mammal } & Grid Locations & (\% Coverage) \\
\hline & Nursery & Fort & Upland & Zoo \\
\hline Lonicera morrowii & 68.3 & 83.3 & 88.3 & 45 \\
\hline Malus coronaria & 0.7 & 10 & 0 & 0.2 \\
\hline Fraxinus americana & 1 & 6.8 & 0 & 0 \\
\hline Viburnum dentatum & 1.7 & 0.3 & 0 & 0 \\
\hline Eleagnus umbellata & 0 & 16.7 & 0 & 0 \\
\hline Amelanchier arborea & 0 & 0 & 0 & 0 \\
\hline Robinia pseudoacacia & 0 & 0 & 0 & 0 \\
\hline \multicolumn{5}{|c|}{ a Lonicera morrowii = Morrow's honeysuckle; Malus coronaria = sweet crabapple; } \\
\hline Fraxinus americana $=$ & white ash; & Viburnum dentatı & Im $=$ southern $\operatorname{arr}$ & owwood; Eleagnu \\
\hline
\end{tabular}


Appendix III. Acronym, scientific name, and common name of herbs, shrubs, and trees

that were measured at trap stations and along animal trails at Fort Necessity National

Battlefield (FONE), Fayette County, Pennsylvania, USA in 2004 and 2005. Bold-faced

type indicates exotic species.

\begin{tabular}{|c|c|c|}
\hline Acronym & Species & Common Name \\
\hline ACERUB & Acer rubrum & Red Maple \\
\hline ACESAC & Acer saccharum & Sugar Maple \\
\hline ACHMIL & Achillea millefolium & Common Yarrow \\
\hline AGEALT & Ageratina altissima var. altissima & White Snakeroot \\
\hline AGRGIG & Agrostis gigantea & Redtop \\
\hline AGRGRY & Agrimonia gryposepala & Tall Hairy Agrimony \\
\hline AGRPER & Agrostis perennans & Upland Bentgrass \\
\hline ALLVIN & Allium vineale & Wild Garlic \\
\hline AMBART & Ambrosia artimisiifolia & Ragweed \\
\hline AMEARB & Amelanchier arborea & Downy Serviceberry \\
\hline AMPBRA & Amphicarpaea bracteata & American Hogpeanut \\
\hline ANDVIR & Andropogon virginicus & Broomsedge Bluestem \\
\hline ANTNEG & Antennaria neglecta & Field Pussytoes \\
\hline ANTODO & Anthoxanthum odoratum & Sweet Vernal Grass \\
\hline APOCAN & Apocynum cannabinum & Indian Hemp \\
\hline ARRELA & Arrhenatherum elatius & Tall Oatgrass \\
\hline ASTSPP & Aster spp. & Aster spp. \\
\hline ASTDIV & Aster divaricatus & Heart-leaved aster \\
\hline ASCTUB & Asclepias tuberosa & Butterfly Milkweed \\
\hline ATHFIL & Athyrium filix-femina ssp. angustum & Subarctic Ladyfern \\
\hline BARVUL & Barbarea vulgaris & Garden Yellowrocket \\
\hline BERTHU & Berberis thunbergii & Japanese Barberry \\
\hline BETALL & Betula alleghaniensis & Yellow Birch \\
\hline BOTDIS & Botrychium dissectum & Cutleaf Grapefern \\
\hline BOTVIR & Botrychium virginianum & Rattlesnake Fern \\
\hline BRAERE & Brachyelytrum erectum & Bearded Shorthusk \\
\hline CALSEP & Calystegia sepium & Hedge False Bindweed \\
\hline CARBLA & Carex blanda & Woodland Sedge \\
\hline CARCAR & Carpinus caroliniana & Ironwood \\
\hline CARDEB & Carex debilis var. rudgei & White Edge Sedge \\
\hline CARDIG & Carex digitalis & Slender Woodland Sedge \\
\hline CARDIP & Cardamine diphylla & Crinkleroot \\
\hline CARGLA & Carya glabra & Pignut Hickory \\
\hline CARGRA & Carex granularis & Limestone Meadow Sedge \\
\hline CARDHIR & Cardamine hirsuta & Hairy Bittercress \\
\hline CARHIR & Carex hirsutella & Fuzzy Wuzzy Sedge \\
\hline CARLAX & Carex laxiflora & Broad Looseflower Sedge \\
\hline CARLUR & Carex lurida & Shallow Sedge \\
\hline
\end{tabular}


Appendix III. Continued.

\begin{tabular}{|c|c|c|}
\hline Acronym & Species & Common Name \\
\hline CARMOL & Carex molesta & Troublesome Sedge \\
\hline CARNOR & Carex normalis & Greater Straw Sedge \\
\hline CARRAD & Carex radiata & Eastern Star Sedge \\
\hline CARSPP & Carex spp. & A sedge \\
\hline CARSTI & Carex stipata & Owlfruit Sedge \\
\hline CARSTR & Carex stricta & Upright Sedge/Tussock Sedge \\
\hline CARSWA & Carex swanii & Swan's Sedge \\
\hline CARTOM & Carya tomentosa & Mockernut Hickory \\
\hline CARVIR & Carex virescens & Ribbed Sedge \\
\hline CARVUL & Carex vulpinoidea & Fox Sedge \\
\hline CERFON & Cerastium fontanum & $\begin{array}{l}\text { Common Mouse-ear } \\
\text { Chickweed }\end{array}$ \\
\hline CINARU & Cinna arundinaceae & Sweet Woodreed \\
\hline CIRARV & Cirsium arvense & Canada Thistle \\
\hline CIRLUT & Circaea lutetiana & $\begin{array}{l}\text { Broadleaf Enchanter's } \\
\text { Nightshade }\end{array}$ \\
\hline CIRVUL & Cirsium vulgare & Bull Thistle \\
\hline CLEVIR & Clematis virginiana & Virgin's Bower \\
\hline CLIVUL & Clinopodium vulgare & Wild Basil \\
\hline CONARV & Convolvulus arvensis & Field Bindweed \\
\hline CORFLO & Cornus florida & Flowering Dogwood \\
\hline CORRAC & Cornus racemosa & Gray Dogwood \\
\hline CORSER & Cornus sericea & Redosier Dogwood \\
\hline CORVAR & Coronilla varia & Crown Vetch \\
\hline CRAPRU & Crataegus pruinosa & Waxyfruit Hawthorne \\
\hline CRASPP & Crataegus spp. & Hawthorne \\
\hline DACGLO & Dactylis glomerata & Orchard Grass \\
\hline DANCOM & Danthonia compressa & Flattened Oatgrass \\
\hline DANSPP & Danthonia spp. & Danthonia spp. \\
\hline DANSPI & Danthonia spicata & Poverty Oatgrass \\
\hline DAUCAR & Daucus carota & Queen Anne's Lace \\
\hline DENPUN & Dennstaedtia punctilobula & Eastern Hayscented Fern \\
\hline DESCAN & Desmodium canescens & Hoary Ticktrefoil \\
\hline DESPAN & Desmodium paniculatum & Panicledleaf Ticktrefoil \\
\hline DIAARM & Dianthus armeria & Deptford Pink \\
\hline DICACU & Dichanthelium acuminatum var. fasciculatum & Western Panicgrass \\
\hline DICCLA & Dichanthelium clandestinum & Deertongue \\
\hline DICSCA & Dichanthelium scarbriusculum & Wooly Rosette Grass \\
\hline DICSPH & Dichanthelium sphaerocarpon & Roundseed Panicgrass \\
\hline DICSPP & Dichanthelium spp. & Dichanthelium spp. \\
\hline DIOVIL & Dioscorea villosa & Wild Yam \\
\hline DOEUMB & Doellingeria umbellata & Parasol Whitetop \\
\hline DRYCAR & Dryopteris carthusiana & Spinulose Woodfern \\
\hline DRYINT & Dryopteris intermedia & Intermediate Wood Fern \\
\hline ELETEN & Eleocharis tenuis & Slender Spikerush \\
\hline ELYCAN & Elymus canadensis & Canada Wildrye \\
\hline ELYREP & Elymus repens & Quackgrass \\
\hline
\end{tabular}


Appendix III. Continued.

\begin{tabular}{|c|c|c|}
\hline Acronym & Species & Common Name \\
\hline ERISTR & Erigeron strigosus var. strigosus & Prairie Fleabane \\
\hline EUOALA & Euonymus alatus & Winged Euonymus \\
\hline EURDIV & Eurybia divaricatus & White Wood Aster \\
\hline EUTGRA & Euthamia graminifolia & Flat-top Goldentop \\
\hline FRAAME & Fraxinus americana & White Ash \\
\hline FAGGRA & Fagus grandifolia & American Beech \\
\hline FESOVI & Festuca ovina & Viviparous Sheep Fescue \\
\hline FRAVIR & Fragaria virginiana & Virginia Strawberry \\
\hline GALCIR & Gallium circaezans & Licorice Bedstraw \\
\hline GALTRI & Gallium triflorum & Fragrant Bedstraw \\
\hline GENCLA & Gentian clausa & Bottle Gentian \\
\hline GERMAC & Geranium maculatum & Wild Geranium \\
\hline GEUCAN & Geum canadense & White Avens \\
\hline GLEHED & Glechoma hederaceae & Ground Ivy \\
\hline GLYSTR & Glyceria striata & Fowl Mannagrass \\
\hline HIEAUR & Hieracium aurantiacum & Orange Hawkweed \\
\hline HIECAE & Hieracium caespitosum & Meadow Hawkweed \\
\hline HOLLAN & Holcus lanatus & Common Velvet Grass \\
\hline HOUPUR & Houstonia purpurea var. purpurea & Purple Bluets \\
\hline HYPPUN & Hypericum punctatum & Spotted St. John's Wort \\
\hline HYPRAD & Hypochaeris radicata & Hairy Catsear \\
\hline IMPCAP & Impatiens capensis & Jewelweed \\
\hline IPOPAN & Ipomea pandurata & Man of the Earth \\
\hline JUNEFF & Juncus effusus & Bulrush \\
\hline JUNSEC & Juncus secundus & Lopsided Rush \\
\hline JUNTEN & Juncus tenuis & Poverty Rush \\
\hline LACCAN & Lactuca canadensis & Canada Lettuce \\
\hline LEEORY & Leersia oryzoides & Rice Cutgrass \\
\hline LEEVIR & Leersia virginica & Whitegrass \\
\hline LEUVUL & Leucanthemum vulgare & Oxeye Daisy \\
\hline LILCAN & Lilium canadense & Canada Lilly \\
\hline LINBEN & Lindera benzoin & Spicebush \\
\hline LINSTR & Linum striatum & Ridged Yellow Flax \\
\hline LIRTUL & Liriodendron tulipifera & Tulip Poplar \\
\hline LOBINF & Lobelia inflata & Indian-tobacco \\
\hline LOLARU & Lolium arundinaceum & Tall Fescue \\
\hline LONMOR & Lonicera morrowii & Morrow's Honeysuckle \\
\hline LUZACU & Luzula acuminata & Hairy Woodrush \\
\hline LYCDIG & Lycopodium digitatum & Fan Clubmoss \\
\hline LYCUNI & Lycopus uniflorus & Northern Bugleweed \\
\hline LYCVIR & Lycopus virginicus & Virginia Water Horehound \\
\hline LYSLAN & Lysimachia lanceolata & Lanceleaf Loosestrife \\
\hline LYSQUA & Lysimachia quadriflora & Whorled Loosestrife \\
\hline MAGACU & Magnolia acuminata & Cucumbertree \\
\hline MALCOR & Malus coronaria & Sweet Crabapple \\
\hline MALPUM & Malus pumila & Paradise Apple \\
\hline
\end{tabular}


Appendix III. Continued.

\begin{tabular}{|c|c|c|}
\hline Acronym & Species & Common Name \\
\hline MELOFF & Melilotus officinalis & Yellow Sweet-clover \\
\hline MICVIM & Microstegium vimineum & Japanese Stiltgrass \\
\hline MIMRIN & Mimulus ringens & Allegheny Monkeyflower \\
\hline MITDIP & Mitella diphylla & Twoleaf Miterwort \\
\hline MITREP & Mitchella repens & Partridgeberry \\
\hline MONUNI & Monotropa uniflora & Indian Pipe \\
\hline $\mathrm{MUHSCH}$ & Muhlenbergia schreberi & Nimblewill \\
\hline MUHSPP & Muhlenbergia spp. & Muhly \\
\hline NYSSYL & Nyssa sylvatica & Black Gum \\
\hline OENPER & Oenethera perennis & Little Evening Primrose \\
\hline ONOSEN & Onoclea sensibilis & Sensitive Fern \\
\hline OPHVUL & Ophioglossum vulgatum & Southern Adder's-tongue \\
\hline OSMCIN & Osmunda cinnamomea & Cinnamon Fern \\
\hline OSMCLA & Osmorhiza claytonii & Clayton's Sweetroot \\
\hline OXASTR & Oxalis stricta & Common Yellow Oxalis \\
\hline PACAUR & Packera aurea & Golden Ragwort \\
\hline PANSPP & Panicum spp. & Panic Grass \\
\hline PARQUI & Parthenocissus quinquefolia & Virginia Creeper \\
\hline PEDCAN & Pedicularis canadensis & Lousewort \\
\hline PENDIG & Penstemon digitalis & Foxglove Beard-tongue \\
\hline PHLPRA & Phleum pratense & Timothy \\
\hline PHYHET & Physalis heterophylla & Clammy Groundcherry \\
\hline PICRUB & Picea rubens & Red Spruce \\
\hline PINRES & Pinus resinosa & Red Pine \\
\hline PINSER & Pinus serotina & Pond Pine \\
\hline PINSTR & Pinus strobus & Eastern White Pine \\
\hline PLALAC & Platanthera lacera & Green-fringed Orchid \\
\hline PLALAN & Plantago lanceolata & Narrowleaf Plantain \\
\hline PLARUG & Plantago rugelii & Blackseed Plantain \\
\hline POAALS & Poa alsodes & Grove bluegrass \\
\hline POASPP & Poa spp. & Poa spp. \\
\hline POATRI & Poa trivialis & Rough Bluegrass \\
\hline PODPEL & Podophyllum peltatum & Mayapple \\
\hline POLACR & Polystichum acrostichoides & Christmas Fern \\
\hline POLBIF & Polygonatum biflorum & Solomon's-seal \\
\hline POLPER & Polygonum persicaria & Spotted Ladysthumb \\
\hline POLSAG & Polygonum sagittatum & Arrowleaf Tearthumb \\
\hline POLSAN & Polygala sanguinea & Purple Milkwort \\
\hline POLVIR & Polygonum virginianum & Jumpseed \\
\hline POPDEL & Populus deltoides & Eastern Cottonwood \\
\hline POPGRA & Populus grandidentata & Bigtooth Aspen \\
\hline POTSIM & Potentilla simplex & Common Cinquefoil \\
\hline PRESPP & Prenanthes spp. & Rattlesnakeroot \\
\hline PRUSER & Prunus serotina & Black Cherry \\
\hline PRUVUL & Prunella vulgaris var. vulgaris & Common Selfheal \\
\hline PTEAQU & Pteridium aquilinum & Western Brackenfern \\
\hline
\end{tabular}


Appendix III. Continued.

\begin{tabular}{|c|c|c|}
\hline Acronym & Species & Common Name \\
\hline QUEALB & Quercus alba & White Oak \\
\hline QUECOC & Quercus coccinea & Scarlet Oak \\
\hline QUERUB & Quercus rubra & Northern Red Oak \\
\hline QUEVEL & Quercus velutina & Black Oak \\
\hline RANACR & Ranunculus acris & Tall Buttercup \\
\hline RHOPER & Rhododendron periclymenoides & Pink Azalea \\
\hline RHUCOP & Rhus copallinum & Winged Sumac \\
\hline ROBPSE & Robinia pseudoacacia & Black Locust \\
\hline ROSMUL & Rosa multiflora & Multiflora Rose \\
\hline RUBFLA & Rubus flagellaris & Northern Dewberry \\
\hline RUBSPP & Rubus spp. & Rubus spp. \\
\hline RUBHIS & Rubus hispidus & Bristly Dewberry \\
\hline RUDHIR & Rudbeckia hirta & Blackeyed Susan \\
\hline RUMACE & Rumex acetosella & Sheep Sorrel \\
\hline RUMCRI & Rumex crispus & Curly Dock \\
\hline SAMNIG & Sambucus nigra spp. canadensis & Common Elderberry \\
\hline SASALB & Sassafras albidum & Sassafras \\
\hline SANCAN & Sanicula canadensis & Canadian Black Snakeroot \\
\hline SISANG & Sisyrinchium angustifolium & Narrowleaf Blue-eyed Grass \\
\hline SMIGLA & Smilax glauca & Cat Greenbrier \\
\hline SMIROT & Smilax rotundifolia & Roundleaf Greenbrier \\
\hline SMITAM & Smilax tamnoides & Bristly Greenbrier \\
\hline SOLCAE & Solidago caesia var. curtisii & Mountain Decumbent Goldenrod \\
\hline SOLCAN & Solidago canadensis & Canada Goldenrod \\
\hline SOLCAR & Solanum carolinense & Carolina Horsenettle \\
\hline SOLJUN & Solidago juncea & Early Goldenrod \\
\hline SOLNEM & Solidago nemoralis & Gray Goldenrod \\
\hline SOLRUG & Solidago rugosa & Wrinkleleaf Goldenrod \\
\hline STELON & Stellaria longifolia & Longleaf Starwort \\
\hline SYMFOE & Symplocarpus foetidus & Skunk Cabbage \\
\hline SYMLAT & Symphyotrichum lateriflorum & Calico Aster \\
\hline SYMPRE & Symphyotrichum prenanthoides & Crookedstem Aster \\
\hline SYMPUN & Symphyotrichum puniceum & Purplestem Aster \\
\hline TAROFF & Taraxacum officinale & Common Dandelion \\
\hline THADIO & Thalictrum dioicum & Early Meadow-rue \\
\hline THENOV & Thelypteris noveboracensis & New York Fern \\
\hline TOXRAD & Toxicodendron radicans & Eastern Poison Ivy \\
\hline TRIAUR & Trifolium aureum & Golden Clover \\
\hline TRIPRA & Trifolium pratense & Red Clover \\
\hline TRIREP & Trifolium repens & White Clover \\
\hline UVUPER & Uvularia perfoliata & Perfoliate Bellwort \\
\hline UVUSES & Uvularia sessilifolia & Sessileleaf Bellwort \\
\hline VACPAL & Vaccinium pallidum & Blue Ridge Blueberry \\
\hline VACSTA & Vaccinium stamineum & Deerberry \\
\hline VERARV & Veronica arvensis & Corn Speedwell \\
\hline VERGIG & Vernonia gigantea ssp. gigantea & Giant Ironweed \\
\hline
\end{tabular}


Appendix III. Continued.

\begin{tabular}{|l|l|l|}
\hline \multicolumn{2}{|c|}{ Species } & \multicolumn{1}{c|}{ Common Name } \\
\hline VERNOV & Vernonia noveboracensis & New York Ironweed \\
\hline VEROFF & Veronica officinalis & Common Gypsyweed \\
\hline VERSER & Veronica serpyllifolia & Thymeleaf Speedwell \\
\hline VERURT & Verbena urticifolia & White Vervain \\
\hline VIBDEN & Viburnum dentatum var. Iucidum & Southern Arrowwood \\
\hline VIBLEN & Viburnum lentago & Nannyberry \\
\hline VIOBLA & Viola blanda & Sweet White Violet \\
\hline VIOCON & Viola conspersa & American Dog Violet \\
\hline VIOROT & Viola rotundifolia & Roundleaf Yellow Violet \\
\hline VIOSAG & Viola sagittata & Arrowleaf Violet \\
\hline VIOSOR & Viola sororia & Common Blue Violet \\
\hline VITAES & Vitis aestivalis & Summer Grape \\
\hline VITROT & Vitis rotundifolia & Muscadine Grape \\
\hline ZIZAPT & Zizia aptera & Meadow Zizia \\
\hline
\end{tabular}


Appendix IVa. Location of the earthworm plots at Fort Necessity National Battlefield (FONE) in Fayette County, Pennsylvania, USA during 2004 and 2005. Two hundred and ninety earthworm plots were dug within the area outlined by the yellow line.

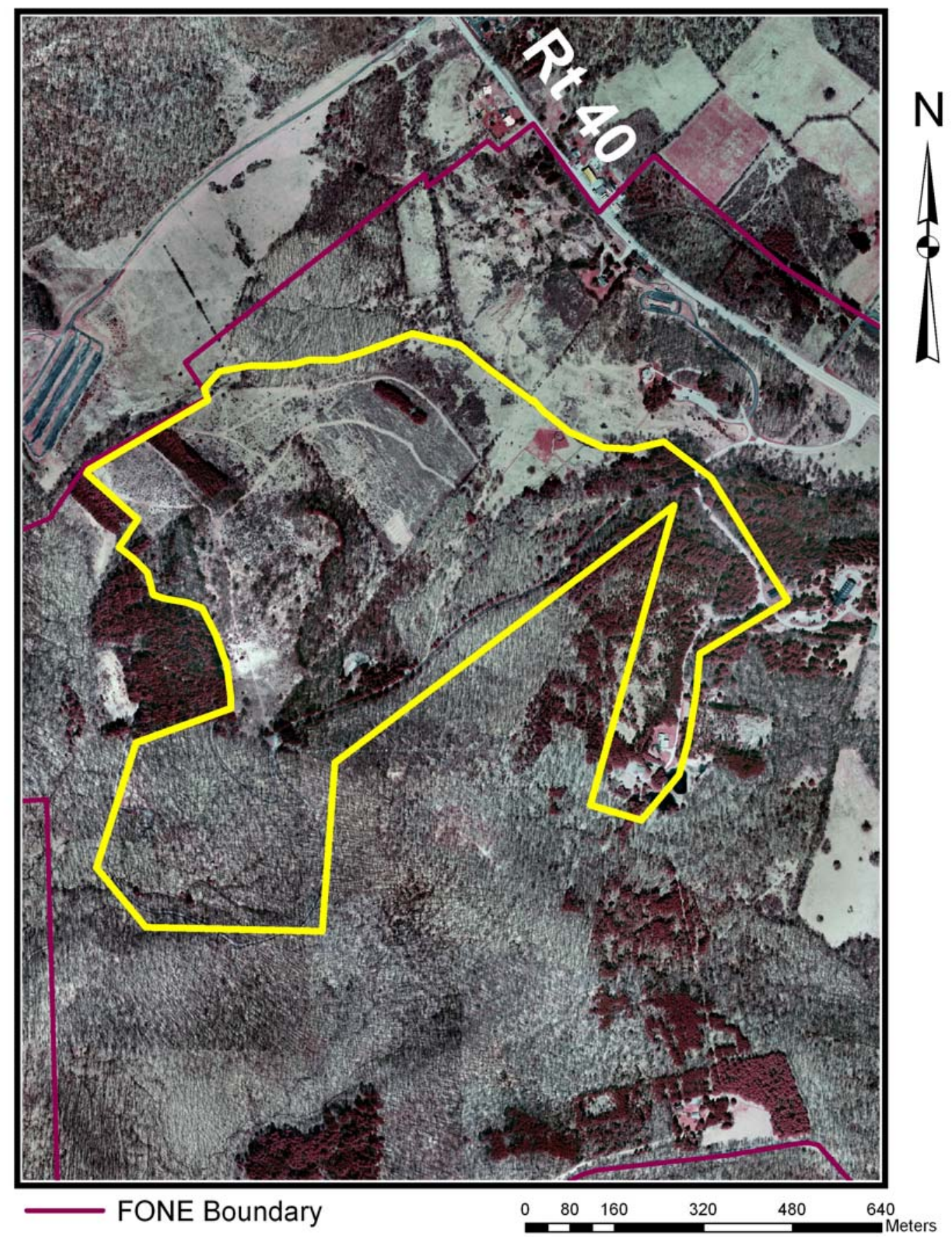

Earthworm Sampling Boundary 
Appendix IVb. Depiction of the soil types within the earthworm sampling boundary at Fort Necessity National Battlefield in Fayette County, Pennsylvania, USA during 2004 and 2005. The soils include Philo silt loams $(\mathrm{Ph})$ in the wetland area, Brinkerton and Armagh silt loams $(\mathrm{BaB})$ on $0-8 \%$ slopes, Cavode silt loams $(\mathrm{CaC} 2)$ with $8-15 \%$ slopes, Gilpin channery silt loam (GcC2) with $12-20 \%$ slopes.

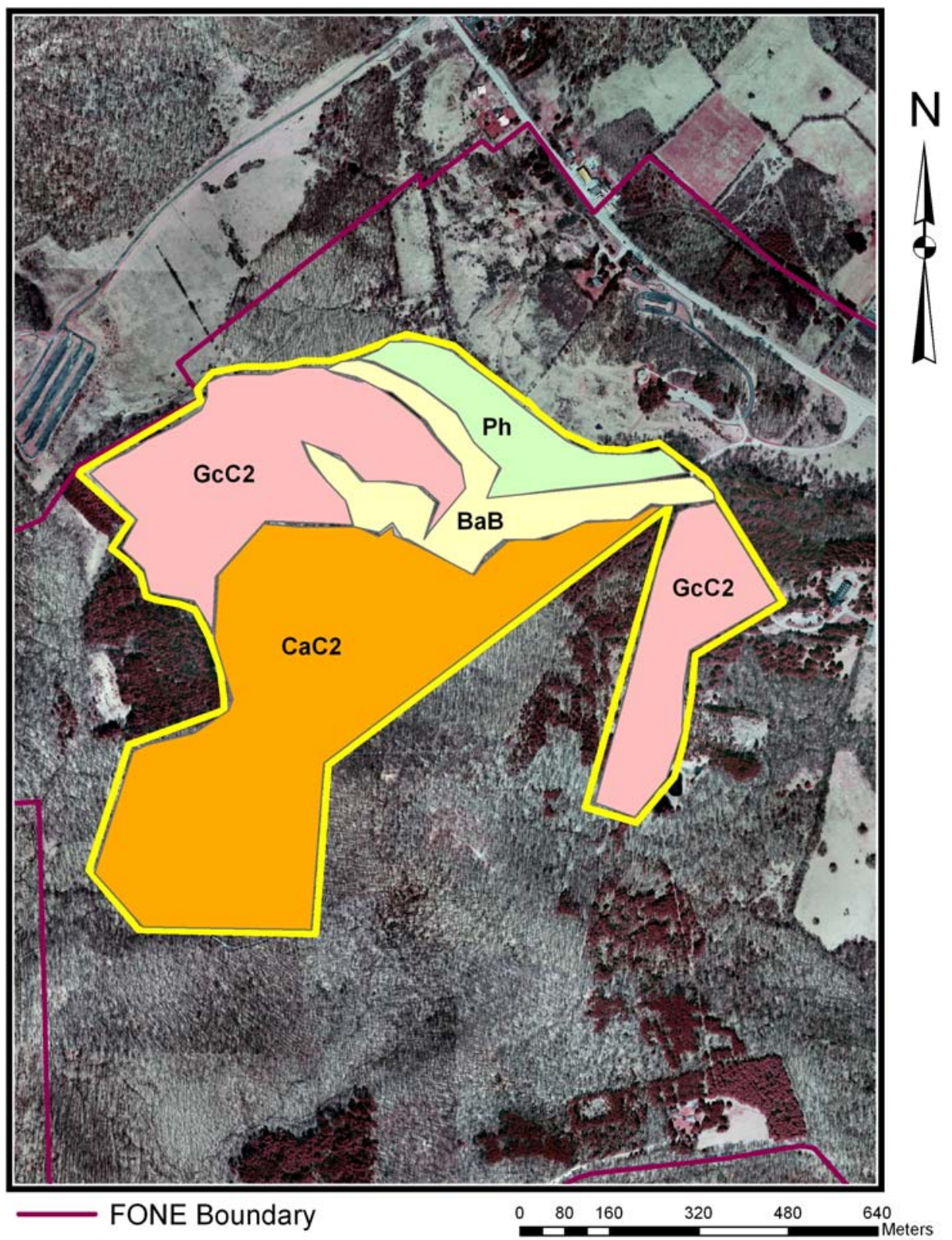


Appendix IVc. Mean earthworm densities (number of worms per square meter) and standard errors (SE) for each earthworm species captured underneath the shrub/tree species in each month (May, Jun., Jul., Aug., Sept.) and year (2004, 2005) at Fort Necessity National Battlefield in Fayette County, Pennsylvania.

\begin{tabular}{|c|c|c|c|c|c|c|c|c|c|c|}
\hline \multirow[b]{3}{*}{ Earthworm Species } & \multicolumn{10}{|c|}{ Plot Location ${ }^{\mathrm{a}}$} \\
\hline & \multicolumn{2}{|c|}{$\mathrm{T}^{\mathrm{b}}$} & \multicolumn{2}{|r|}{$\mathrm{M}^{\mathrm{b}}$} & \multicolumn{2}{|c|}{$\mathrm{O}^{\mathrm{b}}$} & \multicolumn{2}{|c|}{$\mathrm{B}^{\mathrm{b}}$} & \multicolumn{2}{|r|}{$\mathrm{S}^{\mathrm{b}}$} \\
\hline & $\overline{\mathrm{x}}$ & SE & $\bar{x}$ & SE & $\overline{\mathrm{x}}$ & SE & $\overline{\mathrm{x}}$ & SE & $\bar{x}$ & $\mathrm{SE}$ \\
\hline & \multicolumn{4}{|r|}{ July } & \multicolumn{4}{|l|}{2004} & & \\
\hline Eisenia rosea ${ }^{\mathrm{c}}$ & 142.3 & 89.2 & 13.7 & 6.7 & 35.1 & 12.0 & 27.3 & 12.4 & 30.2 & 12.8 \\
\hline Lumbricus rubellus $^{\mathrm{c}}$ & 39.6 & 21.2 & 3.7 & 2.1 & 2.0 & 1.4 & 12.4 & 6.3 & 1.0 & 1.0 \\
\hline Lumbricus terrestris $^{\mathrm{c}}$ & 5.5 & 4.2 & 7.3 & 3.2 & 0.0 & 0.0 & 0.0 & 0.0 & 0.0 & 0.0 \\
\hline \multirow[t]{2}{*}{ Octolasion tyrtaeum ${ }^{\mathrm{c}}$} & 23.2 & 13.6 & 23.7 & 8.2 & 23.4 & 12.5 & 56.1 & 17.4 & 28.4 & 9.4 \\
\hline & \multicolumn{4}{|r|}{ Sept } & \multicolumn{4}{|l|}{2004} & & \\
\hline Eisenia rosea $^{\mathrm{c}}$ & 86.2 & 44.3 & 1.4 & 1.4 & 15.1 & 10.5 & 3.1 & 2.0 & 5.4 & 3.6 \\
\hline Lumbricus rubellus $^{\mathrm{c}}$ & 24.7 & 9.5 & 0.0 & 0.0 & 0.0 & 0.0 & 1.6 & 1.6 & 0.0 & 0.0 \\
\hline Lumbricus terrestris $^{\mathrm{c}}$ & 2.8 & 1.9 & 5.5 & 4.2 & 11.0 & 6.4 & 13.7 & 9.1 & 15.1 & 8.0 \\
\hline \multirow[t]{2}{*}{ Octolasion tyrtaeum ${ }^{\mathrm{c}}$} & 4.1 & 2.9 & 93.0 & 30.0 & 64.4 & 28.6 & 63.9 & 20.2 & 72.5 & 30.4 \\
\hline & \multicolumn{4}{|r|}{ May } & \multicolumn{2}{|l|}{2005} & & & & \\
\hline Eisenia rosea ${ }^{\mathrm{c}}$ & 41.1 & 20.6 & 12.7 & 8.2 & 12.8 & 12.8 & 53.4 & 23.0 & 42.9 & 27.3 \\
\hline Lumbricus rubellus $^{\mathrm{c}}$ & 6.8 & 3.6 & 19.2 & 5.0 & 3.7 & 2.8 & 10.9 & 5.7 & 4.6 & 2.2 \\
\hline Lumbricus terrestris $^{\mathrm{c}}$ & 4.1 & 2.9 & 0.9 & 0.9 & 5.5 & 3.8 & 2.8 & 1.9 & 0.9 & 0.9 \\
\hline \multirow[t]{2}{*}{ Octolasion tyrtaeum ${ }^{\mathrm{c}}$} & 27.4 & 17.1 & 23.2 & 13.6 & 38.3 & 11.2 & 13.7 & 8.6 & 27.3 & 13.7 \\
\hline & \multicolumn{4}{|r|}{ June } & \multicolumn{2}{|l|}{2005} & & & & \\
\hline Eisenia rosea $^{\mathrm{c}}$ & 61.6 & 29.1 & 38.4 & 21.2 & 9.1 & 3.9 & 4.2 & 2.1 & 9.7 & 4.1 \\
\hline Lumbricus rubellus $^{\mathrm{c}}$ & 10.9 & 3.9 & 1.4 & 1.4 & 3.7 & 6.1 & 1.4 & 1.4 & 1.4 & 1.4 \\
\hline Lumbricus terrestris $^{\mathrm{c}}$ & 1.4 & 1.4 & 26.0 & 4.2 & 1.6 & 1.6 & 0.0 & 0.0 & 0.0 & 0.0 \\
\hline
\end{tabular}


Appendix IVc. Continued.

\begin{tabular}{|c|c|c|c|c|c|c|c|c|c|c|}
\hline \multirow[b]{3}{*}{ Earthworm Species } & \multicolumn{10}{|c|}{ Plot Location $^{\mathrm{a}}$} \\
\hline & \multicolumn{2}{|r|}{$\mathrm{T}^{\mathrm{b}}$} & \multicolumn{2}{|c|}{$M^{b}$} & \multicolumn{2}{|c|}{$\mathrm{O}^{\mathrm{b}}$} & \multicolumn{2}{|c|}{$\mathrm{B}^{\mathrm{b}}$} & \multicolumn{2}{|c|}{$S^{b}$} \\
\hline & $\overline{\mathrm{x}}$ & SE & $\bar{x}$ & SE & $\bar{x}$ & SE & $\overline{\mathrm{x}}$ & SE & $\overline{\mathrm{x}}$ & SE \\
\hline \multirow{3}{*}{ Octolasion tyrtaeum ${ }^{\mathrm{c}}$} & \multicolumn{4}{|r|}{ June } & \multicolumn{4}{|c|}{2005} & & \\
\hline & 2.8 & 1.9 & 26.0 & 12.6 & 3.0 & 3.0 & 20.6 & 12.6 & 8.2 & 4.6 \\
\hline & & & \multicolumn{2}{|r|}{ August } & \multicolumn{4}{|c|}{2005} & & \\
\hline Eisenia rosea $^{\mathrm{c}}$ & 86.2 & 44.3 & 23.7 & 9.1 & 6.9 & 4.0 & 27.3 & 13.4 & 18.3 & 8.7 \\
\hline Lumbricus rubellus $^{\mathrm{c}}$ & 24.7 & 9.5 & 0.9 & 0.9 & 0.0 & 0.0 & 0.0 & 0.0 & 3.7 & 2.8 \\
\hline Lumbricus terrestris $^{\mathrm{c}}$ & 2.8 & 1.9 & 1.9 & 1.3 & 0.0 & 0.0 & 0.0 & 0.0 & 0.0 & 0.0 \\
\hline Octolasion tyrtaeum ${ }^{\mathrm{c}}$ & 4.1 & 2.9 & 1.9 & 1.3 & 0.0 & 0.0 & 0.0 & 0.0 & 2.7 & 2.7 \\
\hline
\end{tabular}

${ }^{\mathrm{a}}$ Plot location is the species of shrub/tree where plots were dug $(\mathrm{T}=$ tulip poplar

[Liriodendron tulipifera], $\mathrm{M}=$ Morrow's honeysuckle [Lonicera morrowii], $\mathrm{O}=$ open spaces, $\mathrm{B}=$ black locust [Robinia pseudoacacia], $\mathrm{S}=$ southern arrowwood [Viburnum dentatum]).

${ }^{\mathrm{b}}$ Total plots dug for each shrub in each month and year: July 2004 (Liriodendron tulipifera, $n=10$ plots; Lonicera morrowii, $n=15$ plots; open spaces, $n=14$ plots; Robinia pseudoacacia, $n=10$ plots; Viburnum dentatum, $n=14$ plots); Sept. 2004 (Liriodendron tulipifera, $n=10$ plots; Lonicera morrowii, $n=10$ plots; open spaces, $n=$ 10 plots; Robinia pseudoacacia, $n=9$ plots; Viburnum dentatum, $n=10$ plots); May 2005 (Liriodendron tulipifera, $n=10$ plots; Lonicera morrowii, $n=15$ plots; open spaces, $n=15$ plots; Robinia pseudoacacia, $n=10$ plots; Viburnum dentatum, $n=15$ plots); Jun. 2005 (Liriodendron tulipifera, $n=10$ plots; Lonicera morrowii, $n=10$ plots; open spaces, $n=9$ plots; Robinia pseudoacacia, $n=10$ plots; Viburnum dentatum, $n=10$ plots); Aug. 2005 (Liriodendron tulipifera, $n=10$ plots; Lonicera morrowii, $n=15$ plots; 
Appendix IVc. Continued.

open spaces, $n=14$ plots; Robinia pseudoacacia, $n=10$ plots; Viburnum dentatum, $n=$ 15 plots).

${ }^{c}$ Total worms counted in all plots $(N=290)$ : Eisenia rosea, $n=596$ worms; Lumbricus rubellus, $n=132$ worms; Lumbricus terrestris, $n=85$ worms; Octolasion tyrtaeum, $n=$ 646 worms. 
Fuzyrower80@aol.com; Home Phone: (304)657-0932

CAREER OBJECTIVE

To further my understanding of wild animal populations by working in the wildlife field and to become a certified Wildlife Biologist.

\section{EDUCATION}

West Virginia University

Wildlife and Fisheries Resources

Completion date: Dec 2005; Master of Science Wildlife \& Fisheries Management with Thesis:

The Small Mammal \& Earthworm Communities in a Degraded Ecosystem

\section{University of Georgia \\ Warnell School of Forest Resources}

Bachelor of Science Forest Resources with dual major in Wildlife Management and Forestry

University of Montana

Forestry Professional Program

Completed courses towards a Bachelor of Science Degree in Wildlife Management and Forestry
Missoula, Montana

Athens, Georgia

GPA 3.41

\section{RELEVANT COURSE WORK}

Wildlife Techniques, Wildlife Habitat Management, Ornithology, Vertebrate Natural History, Wetlands, Wildlife Nutrition and Physiology, Forest Ecology, Population Dynamics, Upland Management, Geographic Data Analysis (GIS), Quantitative Ecology, Conservation Biology

\section{RESEARCH EXPERIENCE}

\section{S. Thesis}

- Studied the effects of exotic Morrow's honeysuckle (Lonicera morrowii) on the microhabitat usage of small mammals, the effectiveness of prebaiting small mammal live traps, and the earthworm community related to American Woodcock (Scolopax minor) at Fort Necessity National Battlefield in Fayette County, Pennsylvania from 2004-2005. I have conducted singing song surveys of male American Woodcock along with flush counts to gain a relative abundance of this gamebird whose population has been declining in the East since the 1960s. I monitored pitfall/drift fence arrays for all fauna that are captured. I identified vegetative species growing at our site (grasses, forbs, sedges, ferns, shrubs, and trees) because knowing the food and cover currently available to the small mammals, birds, and herpetofauna is extremely important in understanding how removal of Morrow's honeysuckle (the dominant shrub) will affect the fauna. I have co-written a Management Plan for Fort Necessity focusing on the wildlife response to the Park's future removal of Morrow's honeysuckle. I have had the opportunity to present this research at 4 professional meetings.

\section{Senior Thesis}

- Research conducted on Ossabaw Island, Georgia in 2002 on the diet habits of feral hogs (Sus scrofa) by data collection and analysis using SAS. Feral hogs were euthanized in the field, at which point I removed the stomach and placed it in a gallon-sized plastic bag for later sorting. All food contents were identified and the volume of each food item was recorded. PowerPoint presentation of research given to faculty, staff, and students. Presentation given to Student Chapter of The Wildlife Society in 2004. 


\section{Wildlife Techniques Research Project}

- Investigated the breeding habits of juvenile versus adult American Coots (Fulica americana) in the Southern U.S.

\section{WORK EXPERIENCE} Wildlife Field Technician

August 2003 - November 2003

- Established grid boundaries and helped set up experiment for trapping small mammals. Baited and processed 1176 traps simultaneously with a team, cleaned traps, and helped to take equipment down.

\section{Conservation Education Contractor} USDA Forest Service (Research and Development)

December 2002 - August 2003

- Aid in an international teen journal about environmental issues by: querying database, providing detailed technical graphs and charts, act as main personnel contact and resource for the public to acquire information about the journal, create graphics.

- Created database for Forest Service budget and responsible for incoming invoices, purchase orders, and continual updates.

\section{Fisheries Technician}

August 2002 - January 2003

- Electro-shocked fish and handled a seining net to sample fish populations in sections of the streams. Data collection about habitat characteristics included taking benthic samples. Microscope analysis of benthic microinvertebrates. Recorded data in Microsoft Excel. Read rain gauge data.

\section{Ecology Field Technician Summer 2002}

- Built herbivore exclosures from rebar, hog-wire, and barbwire. Planted 1000 Chinese Tallow tree (Sapium sebiferum) seedlings and monitored them by daily recording status and watering plants. Also recorded first documentation of the exotic invasive tung oil tree (Aleurites fordii) incursion on the island by tagging thousands of trees. Assisted spotlight surveys for deer in Whitehall Forest (UGA).

\section{Carolina Cross Connection}

Summers 1999, 2000, 2001

- Position: Field Coordinator

Duties: Full-time. Organized jobs for the campers such as building wheelchair ramps, porches, painting houses, and roofing.

- Position: Lead Field Coordinator

Duties: In charge of communication with lumber companies and paint stores. Trained new Field Coordinators.

- Position: Director

Duties: Maintained harmony within staff, campers, cook, and people we worked for. Dealt with conflicts and ensured that campers had a fulfilling time and that the people we worked for were satisfied with the job done and the visitation. Balanced and kept the budget for the camp. Priced and bought food for 70 people at a time and delivered it to the cook.

\section{SPECIAL SKILLS}

- Experience with GIS, Microsoft Works, Microsoft Excel, PowerPoint, ArcMap, Microsoft Access, Word Perfect

- Experience with wetland delineation, mist-netting birds, small mammal and herpetofauna trapping, habitat assessment, orienteering, able to identify all vegetation at current study site

- Experience with firearms, bows, chainsaws, basic automotive skills, construction power tools, and landscaping tools. 


\section{HONORS AND ACTIVITIES}

- Associate Wildlife Biologist

- Hunter's Safety Certification

- Dean's List

- HOPE Scholar

- Presidential Scholar

- Who's Who in America

- Stripling Academic Scholarship

- XI Sigma Pi Honorary Society

- Treasurer of Graduate Student Association (GSA)

- The Forest Steward's Guild

- UGA Student Chapter of The Wildlife Society

- WVU Student Chapter of The Wildlife Society

- Crew/Rowing 4 years in high school +1 year at UGA

- Univ. of MT Rugby Team, UGA Soccer Intramurals, UGA Softball Intramurals

- Rabies Vaccination

(Fall 2003)

- Hantavirus Prevention Training

- CPR and First Aid Certified

- Presented current research at the Wildlife Habitat Symposium in Baltimore, MD (November 2004)

- Presented at the Northeast Section Wildlife and Fisheries Conference, VA Beach, VA (April 2005)

- Presented at West Virginia Academy of Sciences Conference, Morgantown, WV (April 2005)

- Presented at West Virginia Davis College of Ag and Consumer Sciences Symposium, Morgantown, WV (April 2005)

\section{REFERENCES}

Dr. Jim Anderson

Professor Wildlife \& Fisheries

Wildlife and Fisheries Resources

West Virginia University

Morgantown, WV 26506

304-293-2941 x2445

wetland@wvu.edu 


\author{
Dr. John Edwards \\ Professor Wildlife \\ Wildlife and Fisheries Resources \\ West Virginia University \\ Morgantown, WV 26506 \\ 304-293-2941x2492 \\ jedwards@wvu.edu \\ Danielle O'Dell \\ Graduate Researcher \\ University of Arizona \\ School of Renewable Natural Resources \\ Tucson, AZ 85721 \\ 520-271-8286 \\ Danielle@Ag.arizona.edu \\ Dr. Cheryl McCormick \\ Post Doctoral Associate, Ph.D. \\ University of Florida \\ Agronomy Department \\ Gainesville, FL 32611-0610 \\ (352)392-9613 \\ Cheryl@ufl.edu \\ Dr. Barbara McDonald \\ Social Scientist \\ USDA Forest Service \\ 320 Green Street \\ Athens, GA 30602-2044 \\ 706-559-4224 \\ barmac@bigfoot.com
}

